\title{
OXYGEN ISOTOPES AND TRACE ELEMENTS IN THE TIVA CANYON TUFF, YUCCA MOUNTAIN AND VICINITY, NYE COUNTY, NEVADA
}

\section{U.S. GEOLOGICAL SURVEY}

Open-File Report 95-431

Prepared in cooperation with the NEVADA OPERATIONS OFFICE, U.S. DEPARTMENT OF ENERGY, under Interagency Agreement DE-AI08-92NV10874

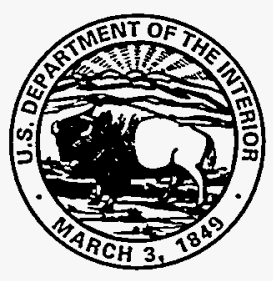




\title{
Oxygen Isotopes and Trace Elements in the Tiva Canyon Tuff, Yucca Mountain and Vicinity, Nye County, Nevada
}

\author{
by Brian D. Marshall, T. Kurtis Kyser, and Zell E. Peterman
}

\section{U.S. GEOLOGICAL SURVEY}

\section{Open-File Report 95-431}

Prepared in cooperation with the

NEVADA OPERATIONS OFFICE,

U.S. DEPARTMENT OF ENERGY, under

Interagency Agreement DE-A108-92NV10874

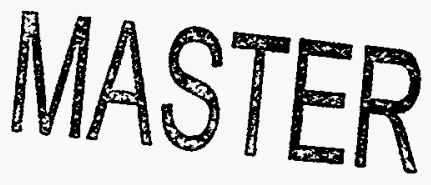

\section{DISCLAIMER}

This report was prepared as an account of work sponsored by an agency of the United States Government. Neither the United States Government nor any agency thereof, nor any of their employees, makes any warranty, express or implied, or assumes any legal liability or responsibility for the accuracy, completeness, or usefulness of any information, apparatus, product, or process disclosed, or represents that its use would not infringe privately owned rights. Reference herein to any specific commercial product, process, or service by trade name, trademark, manufacturer, or otherwise does not necessarily constitute or imply its endorsement, recommendation, or favoring by the United States Government or any agency thereof. The views and opinions of authors expressed herein do not necessarily state or reflect those of the United States Government or any agency thereof.

Denver, Colorado 1996

DISTAIBUTION OF THIS DOCUMENT IS UNLIMATED 


\title{
U.S. DEPARTMENT OF THE INTERIOR BRUCE BABBITT, Secretary
}

\author{
U.S. GEOLOGICAL SURVEY
}

Gordon P. Eaton, Director

The use of firm, trade, and brand names in this report is for identification purposes only and does not constitute endorsement by the U.S. Geological Survey.

For additional information write to:

Chief, Hydrologic Investigations Program Yucca Mountain Project Branch

U.S. Geological Survey

Box 25046, Mail Stop 421

Denver Federal Center

Denver, CO 80225-0046
Copies of this report can be purchased from:

U.S. Geological Survey

Branch of Information Services

Box 25286

Denver, CO 80225-0286 


\section{CONTENTS}

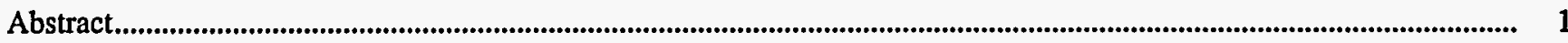

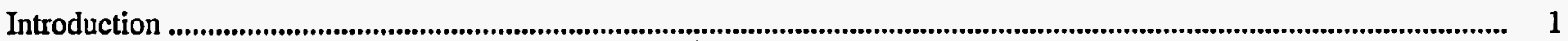

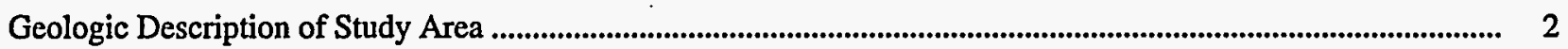

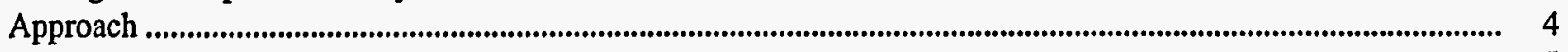

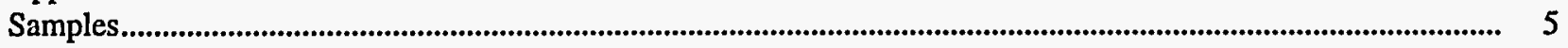

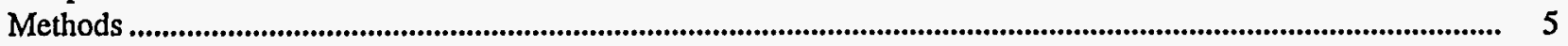

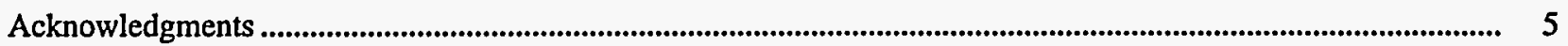

Oxygen Isotopes and Trace Elements in the Tiva Canyon Tuff ............................................................................................... 5

Solitario Canyon Reference Section.................................................................................................................................................... 6

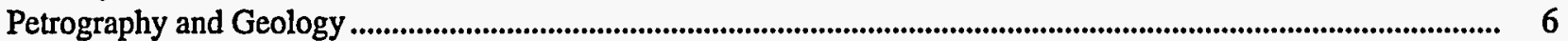

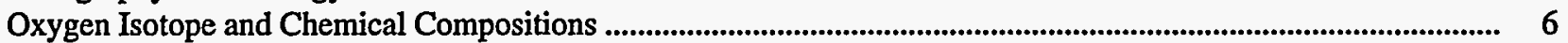

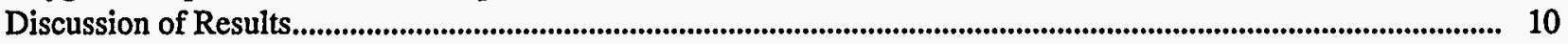

Upper Cliff and Caprock Zones.................................................................................................................................................... 19

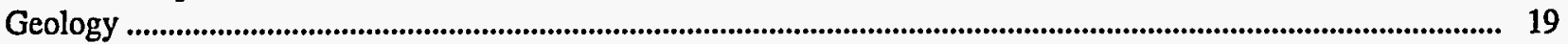

Oxygen Isotope and Chemical Compositions ............................................................................................................ 19

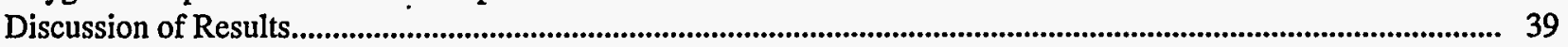

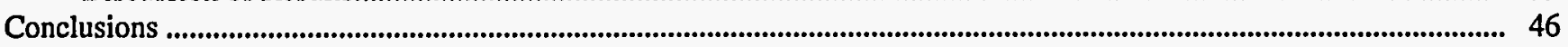

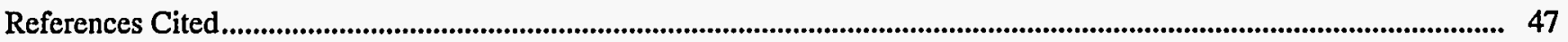

\section{FIGURES}

1. Map showing southern Nevada and location of the Nevada Test Site and the areas shown on

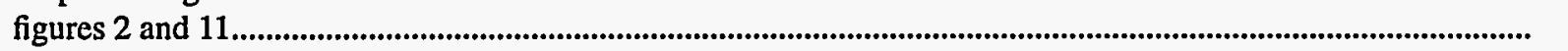

2. Map showing conceptual controlled area, topographic contours, and sample sites for the upper cliff

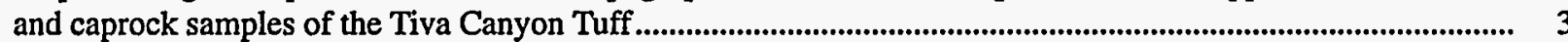

3-10. Graphs showing:

3. Delta ${ }^{18} \mathrm{O}$ values of whole-rock samples as a function of stratigraphic height in the

Tiva Canyon Tuff from the Solitario Canyon reference section

4. Titanium concentration as a function of stratigraphic height in the Tiva Canyon Tuff from the Solitario Canyon reference section.

5. Zirconium and barium concentrations as a function of stratigraphic height in the Tiva Canyon Tuff from the Solitario Canyon reference section

6. Niobium, lanthanum, and cerium concentrations as a function of stratigraphic height in the Tiva Canyon Tuff from the Solitario Canyon reference section.

7. Rubidium and strontium concentrations as a function of stratigraphic height in the Tiva Canyon Tuff from the Solitario Canyon reference section.

8. Potassium and calcium concentrations as a function of stratigraphic height in the Tiva Canyon Tuff from the Solitario Canyon reference section.

9. Variations of barium, cerium, zirconium, niobium, strontium, rubidium, and potassium concentrations as a function of titanium concentration in the Solitario Canyon reference section

10. Variation of calcium and $\delta^{18} \mathrm{O}$ as a function of titanium concentration in the Solitario Canyon reference section

11. Map showing conceptual controlled area and $\delta^{18} \mathrm{O}$ values for the upper cliff and caprock zones.

2-14. Graphs showing:

12. Variations of barium, cerium, zirconium, niobium, strontium, rubidium, potassium, and thorium concentrations as a function of titanium concentration in the Tiva Canyon Tuff upper cliff and caprock samples.

13. Average rare earth element concentrations (normalized to chondritic) of the upper cliff and caprock samples.

14. Variation of calcium, sodium, iron, and uranium concentrations and $\delta^{18} \mathrm{O}$ as a function of titanium concentration in the upper cliff and caprock zones 


\section{TABLES}

1. Lithology and nomenclature of the Tiva Canyon Tuff in the vicinity of Yucca Mountain....................................... 7

2. Geochemistry of the Solitario Canyon reference section at Yucca Mountain ....................................................... 9

3. Map coordinates, sample numbers, and oxygen isotope compositions of the Tiva Canyon Tuff............................ 20

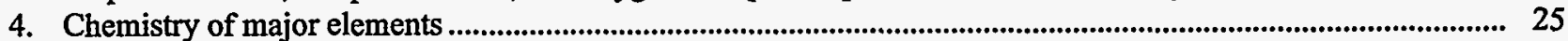

5. Chemistry of common trace elements in the Tiva Canyon Tuff ................................................................................ 29

6. Chemistry of rare earth elements in the Tiva Canyon Tuff.......................................................................................... 34

7. Chemistry of uncommon trace elements........................................................................................................ 41

\section{CONVERSION FACTORS AND VERTICAL DATUM}

\begin{tabular}{rlll}
\hline Multiply & By & & To obtain \\
\hline millimeter $(\mathrm{mm})$ & 0.03937 & inch & \\
meter $(\mathrm{m})$ & 3.2808 & foot & \\
kilometer $(\mathrm{km})$ & 0.6214 & mile & \\
kilogram $(\mathrm{kg})$ & 2.2046 & pound & \\
\hline
\end{tabular}

Sea level: In this report "sea level" refers to the National Geodetic Vertical Datum of 1929 (NGVD of 1929)-a geodetic datum derived from a general adjustment of the first-order level nets of both the United States and Canada, formerly called Sea Level Datum of 1929. 


\title{
Oxygen Isotopes and Trace Elements in the Tiva Canyon Tuff, Yucca Mountain and Vicinity, Nye County, Nevada
}

\author{
By Brian D. Marshall, T. Kurtis Kyser, and Zell E. Peterman
}

\section{Abstract}

Yucca Mountain, located in Nye County, Nevada, is being studied as a potential site for an underground repository for high-level radioactive waste. Because Yucca Mountain is located in a resource-rich geologic setting, one aspect of the site characterization studies is an evaluation of the resource potential at Yucca Mountain.

The Tiva Canyon Tuff is a widespread felsic ash-flow sheet that is well exposed in the Yucca Mountain area. Samples of the upper part of the Tiva Canyon Tuff were selected to evaluate the potential for economic mineral deposits within the Miocene volcanic section. These samples of the upper cliff and caprock subunits have been analyzed for oxygen isotopes and a large suite of elements. Oxygen isotope compositions $\left(\delta^{18} \mathrm{O}\right)$ of the Tiva Canyon Tuff are typical of felsic igneous rocks but range from 6.9 to 11.8 permil, indicating some post-depositional alteration. There is no evidence of the low $\delta^{18} \mathrm{O}$ values (less than 6 permil) that are typical of epithermal precious-metal deposits in the region. The variation in oxygen isotope ratios is probably the result of deuteric alteration during late-stage crystallization of silica and low-temperature hydration of glassy horizons; these processes are also recorded by the chemical compositions of the rocks. However, most elemental contents in the Tiva Canyon Tuff reflect igneous processes, and the effects of alteration are observed only in some of the more mobile elements.
These studies indicate that the Tiva Canyon Tuff at Yucca Mountain has not been affected by large-scale meteoric-water hydrothermal circulation. The chemical compositions of the Tiva Canyon Tuff, especially the low concentrations of most trace elements including typical pathfinder elements, show no evidence for epithermal metal deposits. Together, these data indicate that the potential for economic mineralization in this part of the volcanic section at Yucca Mountain is small.

\section{INTRODUCTION}

Yucca Mountain in Nye County in southern Nevada (fig. 1) is being evaluated as a site for the construction of a potential high-level nuclear waste repository (U.S. Department of Energy, 1988). Yucca Mountain is located in the resource-rich geologic environment of the Basin and Range Province, which has substantial precious-metal production and hydrocarbon and geothermal potential (Ransome, 1907; 1910; Cornwall, 1972; Castor and others, 1990; Grow and others, 1994). Indications of naturally occurring materials or energy sources that would attract exploration and development are potentially adverse conditions (Younker and others, 1992) for a nuclear waste storage site. Thus, a careful assessment of the resource potential of Yucca Mountain is essential for evaluating the suitability of the site. This work is being carried out under the Human Interference Program described in the Site Characterization Plan (U.S. Department of Energy, 1988, Section 8.3.1.9, p. 1-55).

This report describes a geochemical and isotopic study of outcrop samples of the Tiva Canyon Tuff from the conceptual controlled area (fig. 2). The study 


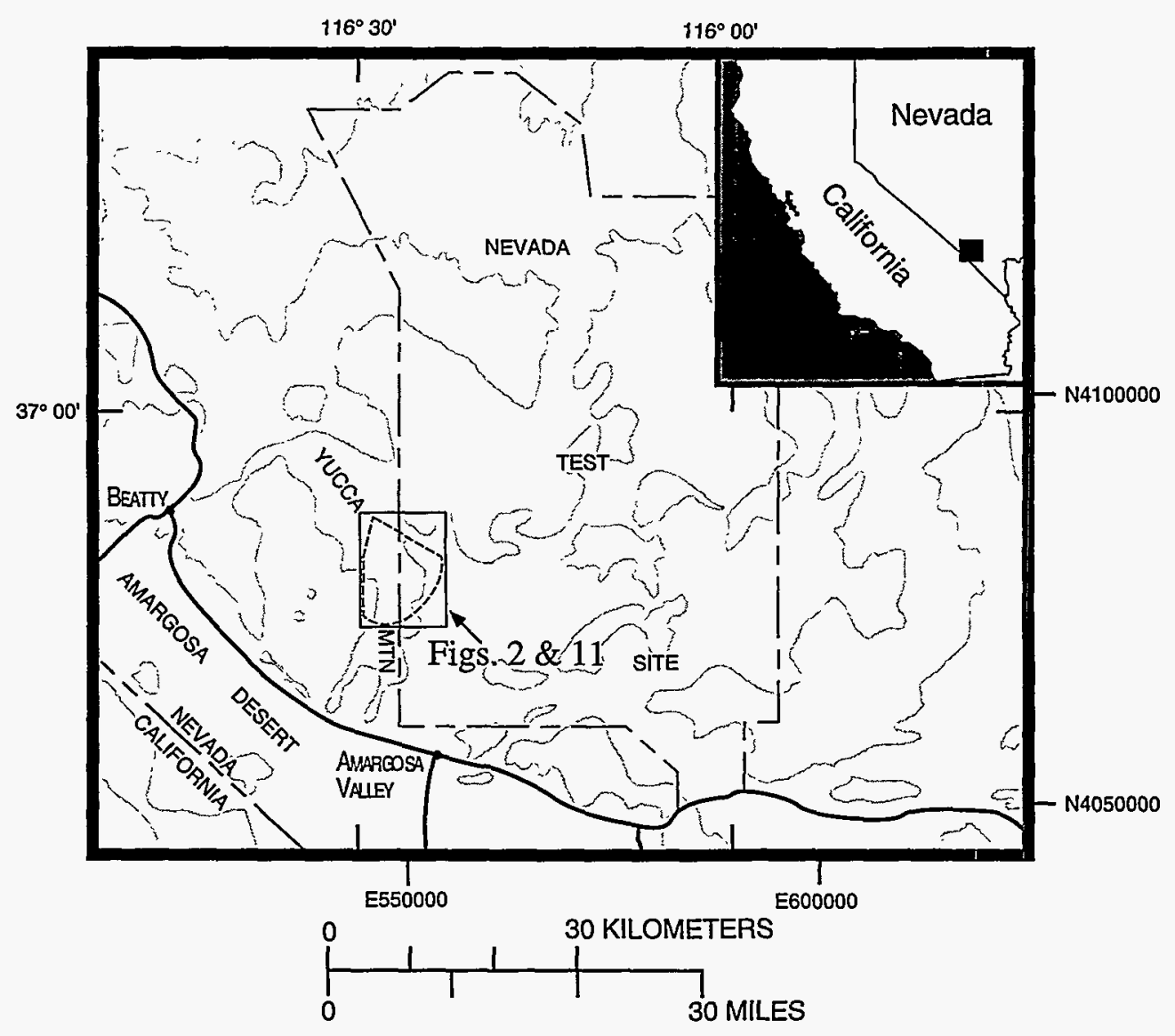

Figure 1. Southern Nevada and location of the Nevada Test Site and the areas shown on figures 2 and 11.

was designed to detect subtle indications of past interactions of the Tiva Canyon Tuff with hydrothermal solutions (heated meteoric waters). Such evidence of intermediate- to high-temperature water-rock interaction may indicate the possibility that mineral deposits may be present in the volcanic rock mass within and beneath the Tiva Canyon Tuff. Previous studies by the U.S. Geological Survey that were related to assessment of mineral resources include: (1) a synthesis of known mineral occurrences (Bergquist and McKee, U.S. Geological Survey, written commun., 1991), (2) an evaluation of the hydrocarbon potential (Grow and others, 1994), (3) the development of isotopic techniques for identifying potentially mineralized Paleozoic limestones (Peterman and others, 1994), and (4) an evaluation of the effects of hydrothermal activity along potential fluid pathways in the volcanic rocks (Neymark and others, 1995). These studies all suggest a low potential for economic resources at Yucca Mountain.

\section{Geologic Description of Study Area}

Yucca Mountain is composed of a thick sequence (up to $1,300 \mathrm{~m}$ ) of late Tertiary felsic ashflow tuffs that were deposited on a basement of Paleozoic carbonate rocks (Spengler and Fox, 1989). Host rocks for potential hydrothermal mineralization include the volcanic rocks of the Paintbrush Group, the underlying Crater Flat Group and older volcanic units that are generally altered to zeolites and other secondary minerals, and Paleozoic and Late Proterozoic sedimentary rocks. In the Basin and Range Province, all of these rock types are known to host both disseminated and vein-type precious-metal deposits (Romberger, 1988, 1993). Within a few tens of kilometers of Yucca Mountain, all of these same rock sequences host precious-metal deposits (Bergquist and McKee, U.S. Geological Survey, written commun., 1991; Peterman and others, 1994; Weiss and others, 1994). 


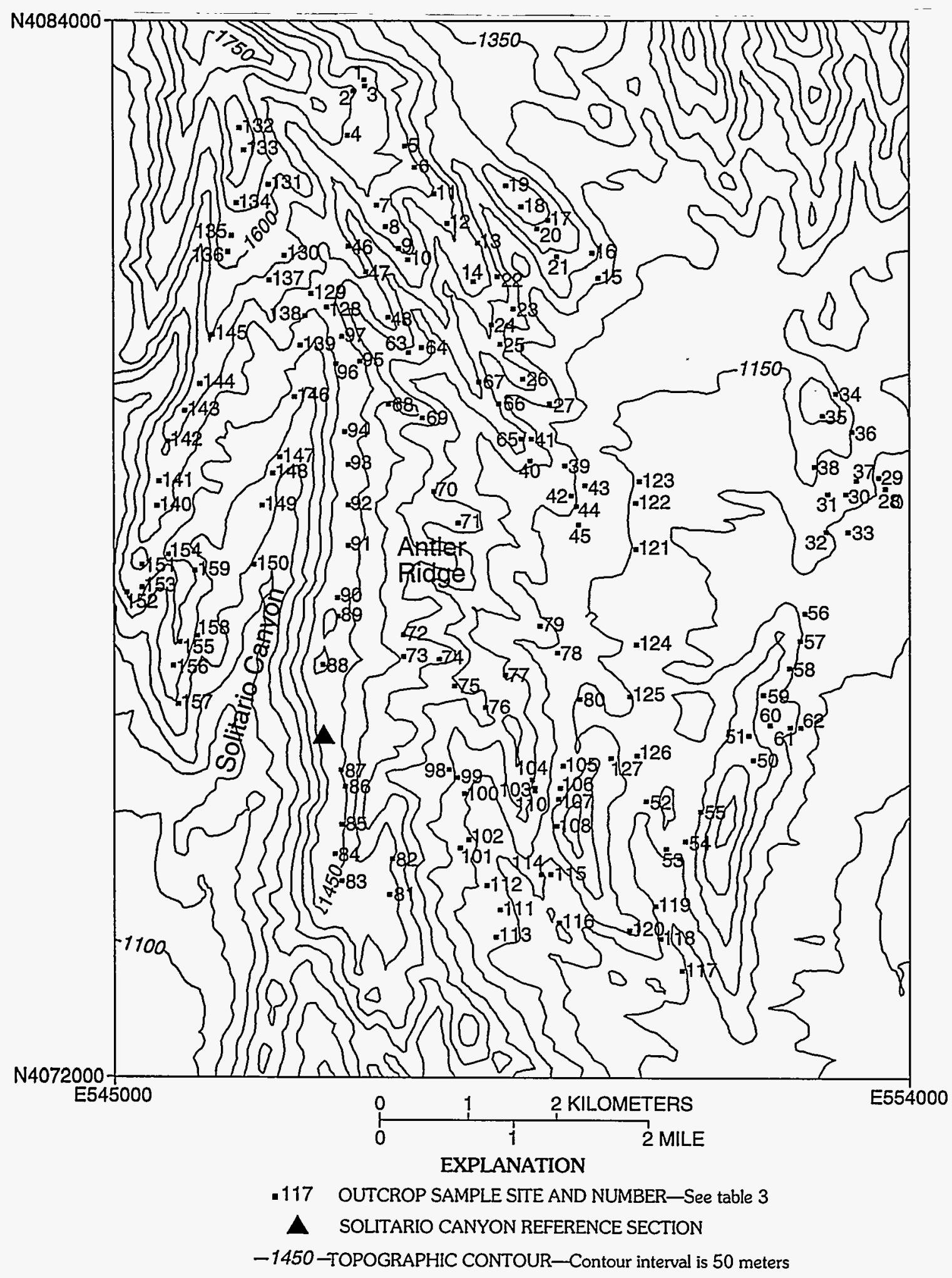

Figure 2. Conceptual controlled area, topographic contours, and sample sites for the upper cliff and caprock samples of the Tiva Canyon Tuff. 
The Tiva Canyon Tuff, the uppermost, densely welded tuff of the Miocene Paintbrush Group, is composed of a compositionally zoned, welded ash-flow tuff (Scott and Bonk, 1984). The lower three-fourths of the unit is composed of high-silica rhyolite that is remarkably uniform in composition regardless of the degree of welding or devitrification; the upper onefourth of the unit is composed of quartz latite that is transitional in composition downward to the highsilica rhyolite (Scott and Bonk, 1984; Flood and others, 1989). The Tiva Canyon Tuff is exposed extensively along ridges and valley walls at Yucca Mountain (Scott and Bonk, 1984). The quartz latite is distinguished from the high-silica rhyolite by the presence of microphenocrysts of biotite, feldspar, and lesser pyroxene, whereas the high-silica rhyolite is generally phenocryst poor (Broxton and others, 1989; Singer and others, 1994).

\section{Approach}

Mineralization of volcanic and sedimentary rocks in the Basin and Range Province was a consequence of ascending hydrothermal solutions that, under suitable conditions, deposited minerals of economic interest along and adjacent to the fluid pathways in concentrations sufficient to attract exploration and exploitation. In addition to the deposition of ore minerals, the compositions of the host rocks were affected by the hydrothermal solutions. For example, in carbonate-hosted precious-metal deposits of the Bare Mountain area west of Yucca Mountain, the strontium isotope compositions $\left(\delta^{87} \mathrm{Sr}\right)$ in regions of the host limestones were substantially increased from their primary marine values near zero to positive values in excess of +3 (Peterman and others, 1994). Strontium isotope compositions were modified by radiogenic ${ }^{87} \mathrm{Sr}$ scavenged from older basement rocks that was introduced by hydrothermal solutions.

The isotopic composition of oxygen in the host rocks also is strongly perturbed in these epithermal systems as shown by the extensive studies of mineralized Tertiary igneous rocks of the Western United States (Criss and Taylor, 1986). These and other milestone investigations documenting this phenomenon are summarized in a stable-isotope review volume edited by Valley and others (1986). Terrestrial igneous rocks commonly have primary bulk-rock oxygen isotope compositions $\left(\delta^{18} \mathrm{O}\right)$ in the range of +5.5 to
+11.0\% (Taylor and Sheppard, 1986), whereas meteoric waters are strongly depleted in ${ }^{18} \mathrm{O}$ relative to most igneous rocks. For example, ground water in the southern Nevada area has $\delta^{18} \mathrm{O}$ values generally between -14 and $-13 \%$ (Benson and McKinley, $1985) ; \delta^{18} \mathrm{O}$ values were probably more negative during past wetter climate periods (Winograd and others, 1988). Where hydrothermal solutions interact with volcanic rocks, oxygen is exchanged between the waters and rocks such that the rock becomes relatively depleted in ${ }^{18} \mathrm{O}$ (lower $\delta^{18} \mathrm{O}$ values) and the water becomes enriched in ${ }^{18} \mathrm{O}$ (higher $\delta^{18} \mathrm{O}$ values). If the water and rock were to completely equilibrate, their respective $\delta^{18} \mathrm{O}$ values would be a function of the temperature-dependent mineral-water fractionation factors and the ratio of the mass of rock to the mass of water; relatively high water/rock ratios, such as those that characterize most hydrothermal systems, can reduce the $\delta^{18} \mathrm{O}$ value of the rocks by several permil (Criss and Taylor, 1986). Estimating the actual water/rock ratios of such a system depends on a number of additional factors including the nature of the porosity and permeability of the rock and whether the system is open or closed (Ohmoto, 1986). This phenomenon has been well documented in hydrothermal systems of the Western United States (Criss and Taylor, 1986) where the spatial variability of wholerock $\delta^{18} \mathrm{O}$ values clearly delineates the locus of hydrothermal activity by concentric zones of ${ }^{18} \mathrm{O}$ depletion. Thus, oxygen isotope compositions of Tertiary volcanic rocks can be used at Yucca Mountain to determine whether or not these rocks have interacted with hydrothermal fluids in the past. At low water/rock ratios, the isotopic effect of such interaction likely will be more easily detected than physical manifestations such as mineralogical alteration. This approach was suggested by Taylor (1974), is cited in the geochemical exploration literature (Levinson, 1980), and has been used in northeastern Australia to assess the potential of terrestrial Paleozoic volcanogenic rocks for economic mineral deposits (Ewers and others, 1994).

In addition to the evaluation of potential mineralization by using oxygen isotopes as described above, samples were also analyzed for precious metals (gold and silver) that could have been introduced by hydrothermal fluids and other pathfinder elements such as antimony, arsenic, and mercury, commonly associated with this type of mineralization (Romberger, 1988). 


\section{Samples}

One-hundred and fifty-seven samples of the upper cliff and caprock zones of the Tiva Canyon Tuff were collected from the conceptual controlled area (fig. 2). Sampling sites were located by superimposing a rectilinear grid with a spacing of $500 \mathrm{~m}$ on the geologic map of Yucca Mountain (Scott and Bonk, 1984), and specific sites were selected as close to the grid nodes as possible within the constraints of outcrops of the upper cliff. Map coordinates for samples were obtained using a portable Global Positioning System (GPS) receiver and are accurate to $\pm 100 \mathrm{~m}$. Additionally, 38 samples from a measured stratigraphic section (Geslin and Moyer, U.S. Geological Survey, written commun., 1993) of the Tiva Canyon Tuff at Solitario Canyon were collected. These samples were processed identically to the upper cliff and caprock zone samples; however, only a limited set of geochemical data were obtained from them.

Approximately 1 to $2 \mathrm{~kg}$ of sample were collected from outcrops using standard steel hammers. Veins and coatings of surficial calcite, large pumice clasts, and lithic clasts were avoided in collecting the samples. In the laboratory, subsamples were obtained from hand-specimen-size pieces using a 0.5 -inchdiameter diamond drill with deionized coolant water. Two cores approximately 2 inches long were taken with emphasis on the rock matrix. The cores were rinsed in deionized water, dried, and pulverized to approximately 200 mesh using a hardened steel ring and puck mill. Splits of the 200-mesh powders were used for oxygen isotope, neutron activation, and $x$-ray fluorescence analyses.

\section{Methods}

Oxygen isotope compositions were measured at the Department of Geological Sciences, University of Saskatchewan, Canada. Oxygen was obtained by decomposition of about $10 \mathrm{mg}$ of a sample powder using bromine pentafluoride. Samples with calcite were leached with 5 percent acetic acid or 10 percent hydrochloric acid prior to analysis. The isotopic composition of oxygen is reported in units of permil deviations ( $\delta^{18} \mathrm{O}$ values) from Standard Mean Ocean Water (SMOW). Replicate analyses of samples and standards indicate that $\delta^{18} \mathrm{O}$ values are reproducible within 0.5 permil. Instrumental neutron activation analysis was performed by Activation Laboratories, Ltd. in Ontario, Canada. Major elements and common trace elements are determined with a precision of 10 percent or better; uncommon trace elements may have precisions approaching 100 percent at their detection limits. $\mathrm{X}$-ray fluorescence analysis was performed at the U.S. Geological Survey using an energy-dispersive detector; these concentrations are precise to \pm 10 percent. Accuracy of all geochemical data was assured by calibration to a suite of internationally accepted standards.

\section{Acknowledgments}

We thank Rick Moscati and Joe Whelan for providing unpublished data on tridymite. The U.S. Geological Survey is conducting geologic studies for the Department of Energy Site Characterization Project under Interagency Agreement No. DE-AI08$92 N V 10874$.

\section{OXYGEN ISOTOPES AND TRACE ELEMENTS IN THE TIVA CANYON TUFF}

The Tiva Canyon Tuff is the uppermost welded unit of the Paintbrush Group and consists of a basal high-silica rhyolite and an overlying unit of quartz latite that were deposited from an eruption of the Timber Mountain-Oasis Valley caldera complex (Lipman and others, 1966) at 12.7 Ma (Sawyer and others, 1994). Where exposed in incised canyons around Yucca Mountain, the crystal-poor high-silica rhyolite is about $100 \mathrm{~m}$ thick, and the overlying crystal-rich quartz latite has a thickness of about $30 \mathrm{~m}$. Both units show varying degrees of welding, vesicularity, devitrification, and lithophysal development that have been used by Singer and others (1994) as a basis for dividing the Tiva Canyon Tuff exposed at Antler Ridge into five zones. Although these zones are also present in the section of the Tiva Canyon Tuff exposed at Solitario Canyon, which is part of the present study, there are some subtle distinctions pertinent to the variations in $\delta^{18} \mathrm{O}$ values and some elemental contents of the samples. 


\section{SOLITARIO CANYON REFERENCE SECTION}

\section{Petrography and Geology}

Samples collected from a measured reference section of the Tiva Canyon Tuff on the east side of Solitario Canyon (Geslin and Moyer, U.S. Geological Survey, written commun., 1993) traverse a series of zones having distinct physical and petrographic characteristics (table 1, fig. 3). The bottom $13.6 \mathrm{~m}$ is a moderately welded tuff consisting predominately of glass shards and 1 to 3 percent phenocrysts of quartz and sanidine. The glass shards are yellow-brown in transmitted light, although a few of the larger fragments have darker cores that may be relict glass less affected by later alteration. Alteration of the shards must be limited to hydration of the glass because alteration minerals are not observed with the petrographic microscope $(400 \times)$. Only samples from this subzone in the Solitario Canyon section contain significant quantities of glass. Spherulitic and axiolitic intergrowths characteristic of devitrification are rare in this subzone, as are lithophysal cavities. This subzone is below the hackly zone of the Antler Ridge section described by Singer and others (1994).

Above the moderately welded subzone of the Solitario Canyon section is $5.1 \mathrm{~m}$ of crystal-poor vitric tuff, which is also below the hackly zone in the Antler Ridge section of Singer and others (1994). The degree of devitrification is high at the base of the zone and increases upsection, culminating in complete devitrification at the contact with the overlying lower nonlithophysal zone (table 1). Both devitrification and the presence of lithophysae will have significant effects on the $\delta^{18} \mathrm{O}$ values of the whole-rock samples, as will be discussed. The lower nonlithophysal zone, the upper part of which is correlative to the hackly zone at the Antler Ridge section, is a $36 \mathrm{~m}$ thick, devitrified welded tuff with shards that are completely microcrystalline to axiolitic. The degree of welding and contents of spherulites and lithophysae increase upsection in this zone grading into the lower lithophysal zone (table 1), a 6.4-m-thick lithology with relatively abundant lithophysae, tridymite-filled microvesicles and granophyric textures. These textures are indicative of relatively slow cooling in this part of the section and crystallization of tridymite and feldspar from a vapor phase (Smith, 1960; Ross and Smith, 1961; Singer and others, 1994).
The next overlying unit exposed at Solitario Canyon is a crystal-poor nonlithophysal zone $(30.6 \mathrm{~m}$ thick) that corresponds to the clinkstone zone at Antler Ridge (Singer and others, 1994). The Tiva Canyon Tuff in this zone is moderately to densely welded, and the edges of the shards are obscured by microcrystallization or microgranophyres. The tuffs are totally devitrified, as they are in most of the other sections, but fibrous devitrification textures are sparse.

The crystal-poor nonlithophysal zone is overlain by the crystal-rich lithophysal zone near the top of the Solitario Canyon section (table 1, fig. 3 ). This zone is $13.5 \mathrm{~m}$ in thickness and is similar to the lower lithophysal zone, but with more variable, although fewer, lithophysae and pumice fragments. Many of the pumice fragments have granophyric textures, and the moderately welded tuff has been completely devitrified. The abundance of phenocrysts increases upward near the top of the section as this unit grades into the quartz latite in the caprock zone. The lower part of this zone (crystal transition subzone) of the Solitario Canyon section is equivalent to the upper cliff zone described by Singer and others (1994) at Antler Ridge.

\section{Oxygen Isotope and Chemical Compositions}

Delta ${ }^{18} \mathrm{O}$ values of whole-rock samples of the Tiva Canyon Tuff from the Solitario Canyon section range from +7.9 to $+11.8 \%$ (table 2 , fig. 3 ). This range is within the range reported for pristine siliceous volcanic rocks (Taylor, 1968), unlike the low values (less than $6 \%$ ) from rhyolites that have been hydrothermally altered or have a genesis involving meteoric waters, brines, or hydrothermally altered crustal rocks (Hildreth and others, 1984; Taylor, 1986). The $\delta^{18} \mathrm{O}$ values of the tuffs do not vary systematically with stratigraphic height (fig. 3), although the lowest values are in nonlithophysal zones and the highest values are from the high-silica rhyolite of the lowest unit, the moderately welded subzone with relict glass. Within other zones of the high-silica rhyolite, the $\delta^{18} \mathrm{O}$ values are lower than in the glass-rich, moderately welded subzone, but samples with more lithophysae or axiolitic textures tend to have higher values. In the uppermost zones, most values are near $+8 \%$, although the highest $\delta^{18} \mathrm{O}$ values are in samples having more pumice fragments with microcrystalline or granophyric intergrowths. 


\section{DISCLAIMER}

Portions of this document may be illegible in electronic image products. Images are produced from the best available original document. 
Table 1. Lithology and nomenclature of the Tiva Canyon Tuff in the vicinity of Yucca Mountain

[From Buesch and others, 1996]

\begin{tabular}{|c|c|c|c|c|c|c|c|}
\hline \multirow{2}{*}{$\begin{array}{l}\text { Map unit } \\
\text { Caprock zone }\end{array}$} & \multirow{2}{*}{$\begin{array}{l}\text { Symbol } \\
\text { ccr }\end{array}$} & \multicolumn{3}{|c|}{ Subzone units } & \multicolumn{3}{|c|}{ Symbols } \\
\hline & & \multirow[t]{8}{*}{ Crystal-rich } & \multirow[t]{3}{*}{ Vitric zone } & Nonwelded zone & \multirow[t]{8}{*}{ Tpcr } & \multirow[t]{3}{*}{ Tpcrv } & Tpcrv3 \\
\hline & & & & Moderately to densely welded subzone & & & Tpcrv2 \\
\hline & & & & Vitrophyre subzone & & & Tpervl \\
\hline & & & \multirow{5}{*}{$\begin{array}{l}\text { Nonlithophysal zone or } \\
\text { lithophysal zone }\end{array}$} & Pumice-rich subzone & & \multirow{5}{*}{$\begin{array}{l}\text { Tpcrn or } \\
\text { Tpcrl }\end{array}$} & Tpcrn (1)4 \\
\hline & & & & Pumice-poor subzone & & & Tpcrn (1)3 \\
\hline & & & & Pumice-rich subzone & & & Tpcrn (1)2 \\
\hline & & & & Transition subzone & & & Tpcrn (1)1 \\
\hline Upper cliff zone & cuc & & & & & & \\
\hline Upper lithophysal zone & cul & \multirow{8}{*}{$\begin{array}{l}\text { Crystal- } \\
\text { poor }\end{array}$} & \multicolumn{2}{|l|}{ Upper lithophysal zone } & \multirow[t]{8}{*}{ Tpcp } & \multicolumn{2}{|l|}{ Tpcpul } \\
\hline Clinkstone zone & cks & & \multicolumn{2}{|l|}{ Middle nonlithophysal zone } & & \multicolumn{2}{|l|}{ Tpcpmn } \\
\hline Lower lithophysal zone & cll & & \multicolumn{2}{|l|}{ Lower lithophysal zone } & & \multicolumn{2}{|l|}{ Tpcpll } \\
\hline Hackly zone & ch & & \multirow[t]{2}{*}{ Lower nonlithophysal zone } & Hackly subzone & & \multirow[t]{2}{*}{ Tpcpln } & Tpcplnh \\
\hline \multirow[t]{4}{*}{ Columnar zone } & \multirow[t]{4}{*}{ cc } & & & Columnar subzone & & & Tpcplnc \\
\hline & & & \multirow[t]{3}{*}{ Crystal-poor vitric zone } & Vitrophyre subzone & & \multirow[t]{3}{*}{ Tpcpv } & Tpcpv3 \\
\hline & & & & Moderately to densely welded subzone & & & Tpcpv2 \\
\hline & & & & Nonwelded to partially welded subzone & & & Tpcpvl \\
\hline
\end{tabular}




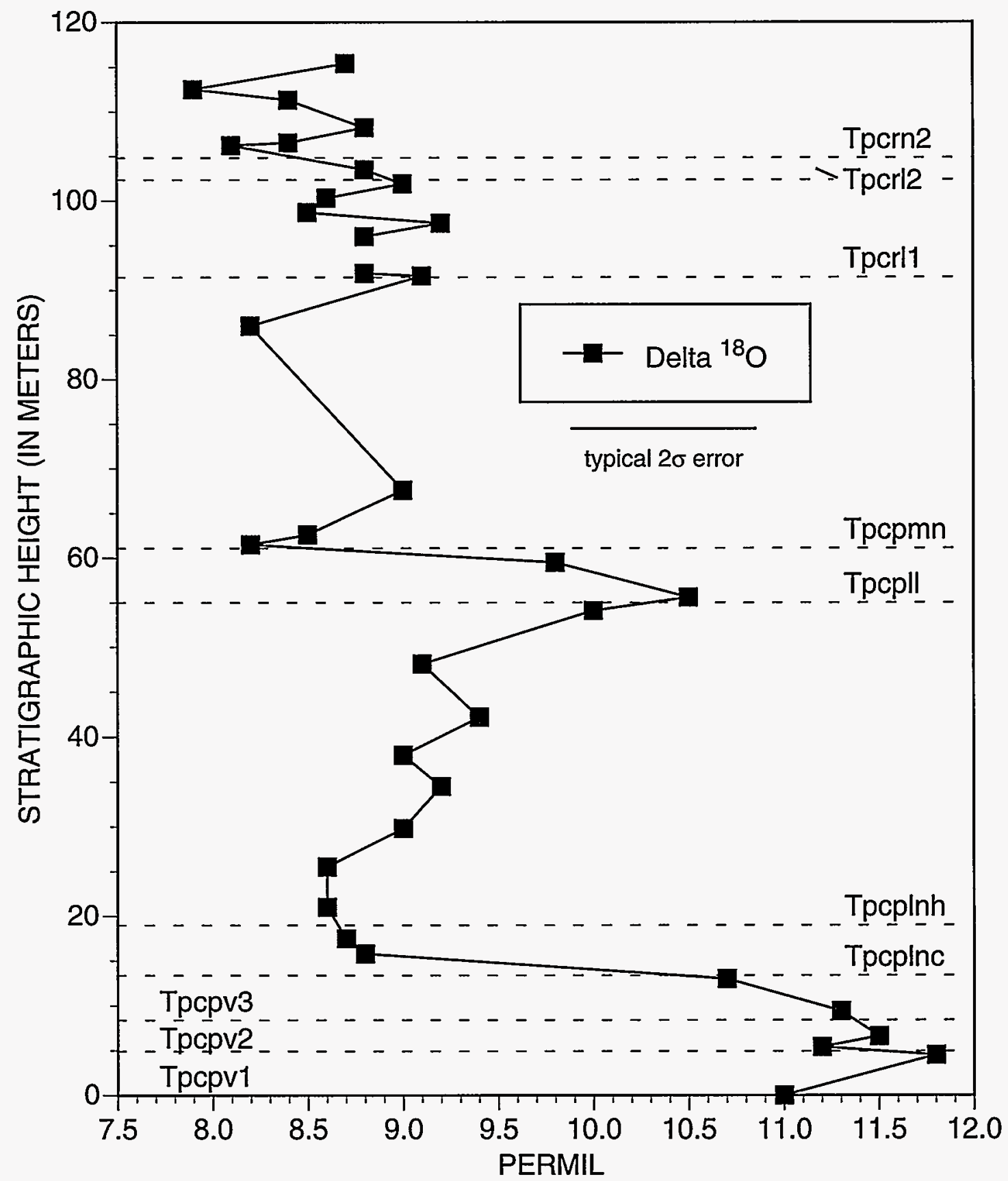

Figure 3. Delta ${ }^{18} \mathrm{O}$ values of whole-rock samples as a function of stratigraphic height in the Tiva Canyon Tuff from the Solitario Canyon reference section. Datum is the base of the Tiva Canyon Tuff. The subunit abbreviations are described in table 1. 
Table 2. Geochemistry of the Solitario Canyon reference section at Yucca Mountain

[\%, percent; $x$-ray fluorescence, in ppm by weight except where noted; position indicates stratigraphic distance above base of Tiva Canyon Tuff in meters]

\begin{tabular}{|c|c|c|c|c|c|c|c|c|c|c|c|c|c|}
\hline $\begin{array}{l}\text { Sample } \\
\text { number }\end{array}$ & Position & $\begin{array}{c}K \\
(\%)\end{array}$ & $\begin{array}{l}\text { Ca } \\
(\%)\end{array}$ & $\pi$ & $\mathbf{R b}$ & $\mathrm{Sr}$ & $\mathbf{Y}$ & $\mathbf{Z r}$ & $\mathbf{N b}$ & $\mathbf{B a}$ & $\mathbf{L a}$ & $\mathrm{Ce}$ & $\begin{array}{l}\delta^{18} 0 \\
(\%)\end{array}$ \\
\hline 3737 & 115.4 & 4.57 & 0.99 & 2,328 & 116 & 96 & 42 & 604 & 19 & 867 & 194 & 289 & 8.7 \\
\hline 3736 & 112.5 & 4.36 & 1.27 & 2,116 & 120 & 84 & 42 & 507 & 18 & 679 & 184 & 281 & 7.9 \\
\hline 3735 & 111.3 & 4.25 & 0.48 & 1,760 & 131 & 64 & 42 & 460 & 21 & 565 & 166 & 251 & 8.4 \\
\hline 3734 & 108.2 & 4.23 & 0.63 & 1,906 & 140 & 65 & 45 & 486 & 20 & 500 & 145 & 230 & 8.8 \\
\hline 3733 & 106.5 & 4.09 & 1.03 & 1,552 & 154 & 76 & 41 & 392 & 22 & 366 & 126 & 196 & 8.4 \\
\hline 3732 & 106.2 & 3.93 & 1.67 & 1,326 & 152 & 50 & 37 & 323 & 26 & 270 & 105 & 154 & 8.1 \\
\hline 3731 & 103.5 & 4.04 & 2.10 & 1,394 & 151 & 71 & 41 & 329 & 25 & 294 & 94 & 147 & 8.8 \\
\hline 3730 & 101.9 & 4.01 & 0.81 & 1,484 & 156 & 48 & 40 & 355 & 25 & 271 & 97 & 164 & 9.0 \\
\hline 3729 & 100.3 & 3.93 & 1.54 & 1,409 & 159 & 54 & 39 & 336 & 26 & 225 & 97 & 142 & 8.6 \\
\hline 3728 & 98.7 & 3.77 & 0.86 & 1,322 & 164 & 48 & 44 & 294 & 26 & 191 & 69 & 118 & 8.5 \\
\hline 3727 & 97.5 & 3.66 & 0.43 & 1,118 & 172 & 42 & 40 & 271 & 31 & 167 & 47 & 81 & 9.2 \\
\hline 3726 & 96.0 & 3.59 & 0.60 & 1,065 & 169 & 45 & 42 & 256 & 30 & 158 & 53 & 90 & 8.8 \\
\hline 4748 & 94.0 & 3.58 & 0.26 & 962 & 180 & 23 & 42 & 226 & 31 & 106 & 53 & 85 & \\
\hline 4747 & 93.3 & 3.53 & 0.51 & 923 & 183 & 23 & 41 & 210 & 30 & 96 & 57 & 82 & \\
\hline 3725 & 91.9 & 3.58 & 0.39 & 840 & 193 & 16 & 41 & 201 & 33 & 67 & 39 & 70 & 8.8 \\
\hline 3724 & 91.6 & 3.50 & 0.67 & 832 & 183 & 24 & 37 & 195 & 32 & 73 & 59 & 80 & 9.1 \\
\hline 3723 & 86.0 & 3.58 & 0.48 & 894 & 194 & 23 & 43 & 209 & 32 & 57 & 54 & 68 & 8.2 \\
\hline 3721 & 67.6 & 3.51 & 0.45 & 865 & 182 & 18 & 38 & 200 & 29 & 65 & 48 & 73 & 9.0 \\
\hline 3720 & 62.6 & 3.52 & 0.35 & 866 & 189 & 14 & 40 & 201 & 33 & 64 & 49 & 85 & 8.5 \\
\hline 3719 & 61.5 & 3.53 & 0.45 & 890 & 188 & 24 & 39 & 203 & 32 & 91 & 43 & 71 & 8.2 \\
\hline 3718 & 59.5 & 3.53 & 0.33 & 873 & 195 & 15 & 41 & 202 & 32 & 70 & 44 & 68 & 9.8 \\
\hline 3717 & 55.6 & 3.54 & 0.37 & 851 & 187 & 17 & 35 & 197 & 31 & 61 & 44 & 72 & 10.5 \\
\hline 3716 & 54.1 & 3.57 & 0.86 & 857 & 186 & 20 & 39 & 195 & 32 & 72 & 45 & 74 & 10.0 \\
\hline 3715 & 48.1 & 3.61 & 0.60 & 891 & 182 & 25 & 38 & 195 & 29 & 84 & 45 & 81 & 9.1 \\
\hline 3714 & 42.2 & 3.60 & 0.49 & 858 & 189 & 18 & 38 & 200 & 32 & 62 & 57 & 82 & 9.4 \\
\hline 3713 & 38.0 & 3.60 & 0.28 & 901 & 194 & 13 & 37 & 217 & 35 & 73 & 50 & 79 & 9.0 \\
\hline 3712 & 34.5 & 3.53 & 0.65 & 869 & 184 & 17 & 41 & 197 & 31 & 58 & 49 & 86 & 9.2 \\
\hline 3711 & 29.8 & 3.52 & 0.19 & 905 & 185 & 13 & 40 & 209 & 32 & 60 & 43 & 79 & 9.0 \\
\hline 3710 & 25.5 & 3.56 & 0.37 & 856 & 180 & 14 & 41 & 195 & 32 & 52 & 47 & 74 & 8.6 \\
\hline 3709 & 21.0 & 3.50 & 0.34 & 882 & 182 & 14 & 39 & 202 & 31 & 64 & 46 & 82 & 8.6 \\
\hline 3708 & 17.5 & 3.56 & 0.30 & 875 & 184 & 14 & 39 & 202 & 33 & 73 & 54 & 80 & 8.7 \\
\hline 3707 & 15.8 & 3.53 & 0.28 & 891 & 186 & 11 & 40 & 202 & 30 & 53 & 56 & 85 & 8.8 \\
\hline 3706 & 13.0 & 4.09 & 0.27 & 833 & 186 & 12 & 39 & 201 & 31 & 40 & 39 & 78 & 10.7 \\
\hline 3705 & 9.4 & 4.12 & 0.30 & 828 & 181 & 15 & 40 & 203 & 31 & 55 & 51 & 80 & 11.3 \\
\hline 3704 & 6.6 & 3.76 & 0.35 & 854 & 174 & 21 & 38 & 198 & 31 & 51 & 46 & 64 & 11.5 \\
\hline 3703 & 5.4 & 3.39 & 0.38 & 867 & 173 & 26 & 39 & 207 & 31 & 50 & 41 & 72 & 11.2 \\
\hline 3702 & 4.5 & 3.24 & 0.79 & 925 & 157 & 52 & 41 & 211 & 32 & 70 & 43 & 67 & 11.8 \\
\hline 3701 & 0.0 & 3.38 & 1.26 & 882 & 147 & 82 & 39 & 204 & 33 & 67 & 49 & 73 & 11.0 \\
\hline
\end{tabular}


In marked contrast to the irregular variation in $\delta^{18} \mathrm{O}$ values with stratigraphic height in samples from the Solitario Canyon section, the titanium, zirconium, barium, niobium, lanthanum and cerium contents of the tuffs vary more regularly (table 2 , figs. $4-6$ ). The concentrations of most of these elements are lowest and constant in the crystal-poor, high-silica rhyolite, but higher and increase regularly upsection in the crystal-rich zones culminating in quartz latite. Niobium contents in the high-silica rhyolite are slightly higher than in the overlying quartz latite. Inasmuch as the high-silica rhyolite was erupted prior to the quartz latite and presumably represents the top of the magma chamber, the increase in both phenocryst content and concentration of these elements in the quartz latite represents a deeper part of the magma chamber. Virtually identical variations in these elements with stratigraphic position have been reported for other sections of the Tiva Canyon Tuff (Broxton and others, 1989; Peterman and Futa, 1996), the underlying Topopah Spring Tuff (Schuraytz and others, 1989; Flood and others, 1989; Neymark and others, 1995), as well as many Quaternary ash-flow tuffs from other areas, including the Bishop Tuff in California (Hildreth, $1979 ; 1981)$ and Los Humeros volcanic center in Mexico (Ferriz and Mahood, 1987). Among the processes that have been proposed to account for these gradients in the chemical composition of silicic magmas are crystal fractionation (Hildreth and Michael, 1983), contamination by roof rocks (Taylor, 1986), selective diffusion (Hildreth, 1979), or combinations of these. Exactly which processes were operating in the magma chamber that produced the apparent gradients in the Tiva Canyon Tuff are as yet unknown and beyond the scope of this study, except to note that the gradients were magmatic in origin and not the result of later alteration.

Concentrations of rubidium, strontium, potassium, and especially calcium in the tuffs from the Solitario Canyon section, vary less regularly with stratigraphic height than most other elements

(table 2, figs. 7 and 8 ). The most significant variation is in the calcium contents of samples from the top of the section. The concentrations of strontium and potassium are higher and the rubidium contents lower in the quartz latite relative to the earlier deposited high-silica rhyolite, but the variation in the contents of these elements within each rock type is greater than that of most other elements. As with most elements, the higher strontium and potassium and lower rubid- ium contents of the quartz latite, which represents a deeper portion of the magma chamber than the highsilica rhyolite, are typical of the chemical gradients observed in many silicic magma chambers (Hildreth, 1981).

\section{Discussion of Results}

Elements such as titanium and zirconium are typically immobile during later alteration events in volcanic rocks (Pearce and Cann, 1973) and, therefore, ratios of their concentrations should refiect magmatic processes. The contents of barium, cerium, zirconium, and niobium not only vary regularly with stratigraphic height, as shown in figures $4-6$, but also vary directly with titanium concentrations, and hence with each other, for all lithologies of the Tiva Canyon Tuff from the Solitario Canyon section (fig. 9). The high-silica rhyolite was the first eruption in the series, representing the top of the magma chamber, and is crystal-poor (less than 2 percent phenocrysts) in part because of the paucity of cumulates. In contrast, the quartz latite presumably represents a higher temperature and deeper portion of the chamber that contained significantly more cumulates as evidenced by 5 to 10 percent modal phenocrysts. Thus, the quartz-latite from the top of the Solitario Canyon section is higher in titanium and other compatible elements than the high-silica rhyolite from the lower portions of the section.

Neither the calcium contents nor $\delta^{18} \mathrm{O}$ values of samples from the Solitario Canyon section vary regularly with titanium contents (fig. 10). To a lesser extent, the strontium, rubidium, and potassium contents do not vary regularly with titanium contents, especially for samples in which the strontium and potassium contents are the lowest (fig. 9). Given that the elements that correlate directly with titanium contents do so because of magmatic processes, those that do not vary with titanium contents most likely reffect nonmagmatic processes, such as post-eruptive alteration.

The lack of correlation between calcium contents and stratigraphic height can be attributed primarily to capricious amounts of secondary carbonate present in the samples from the Solitario Canyon section. Strontium is less affected because strontium to calcium ratios are higher in the tuff than in pedogenic carbonate. This carbonate has high $\delta^{18} \mathrm{O}$ values near +19 , similar to those of vein-filling calcite from the 


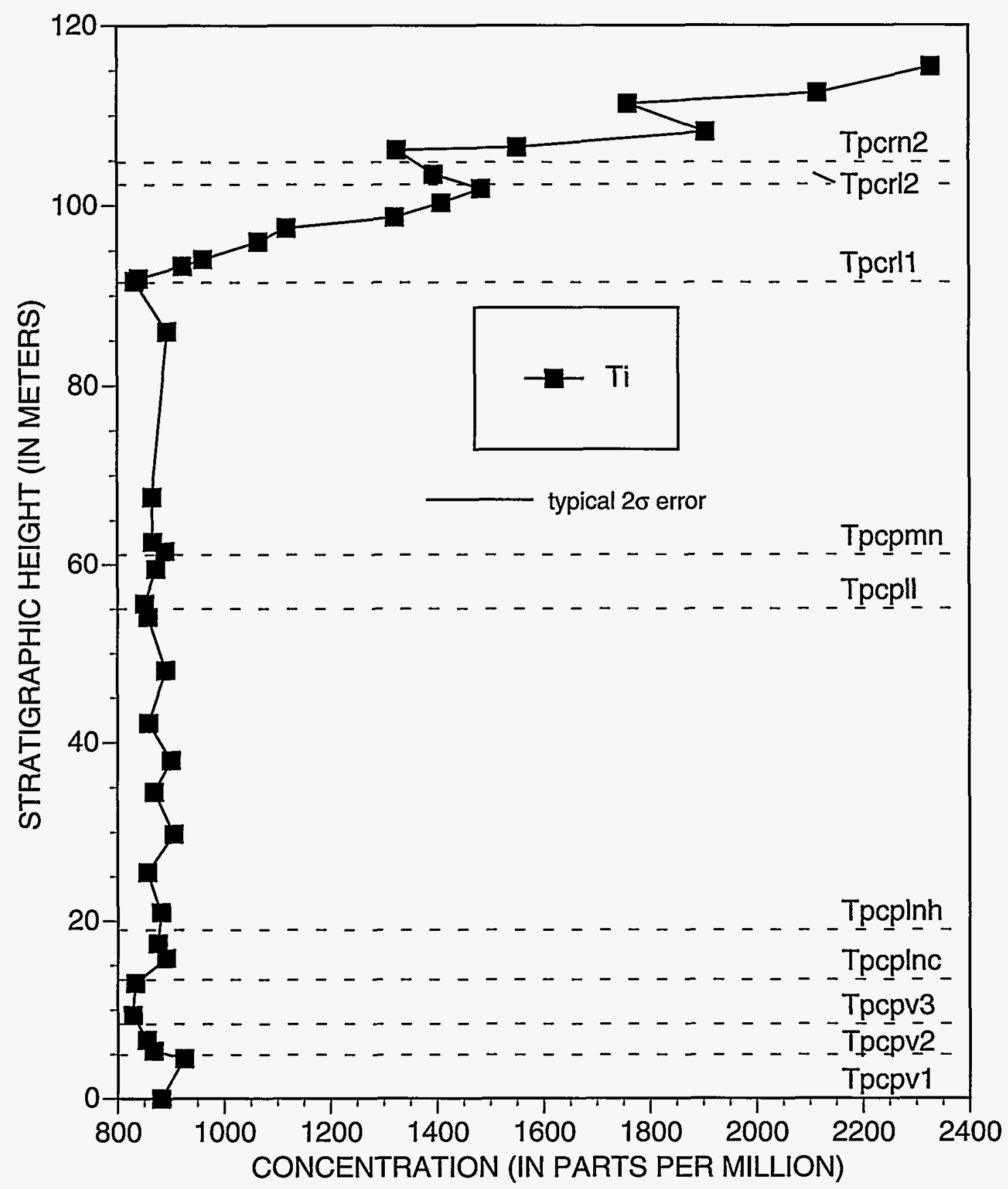

Figure 4. Titanium concentration as a function of stratigraphic height in the Tiva Canyon Tuff from the Solitario Canyon reference section. Datum and abbreviations as in figure 3 . 


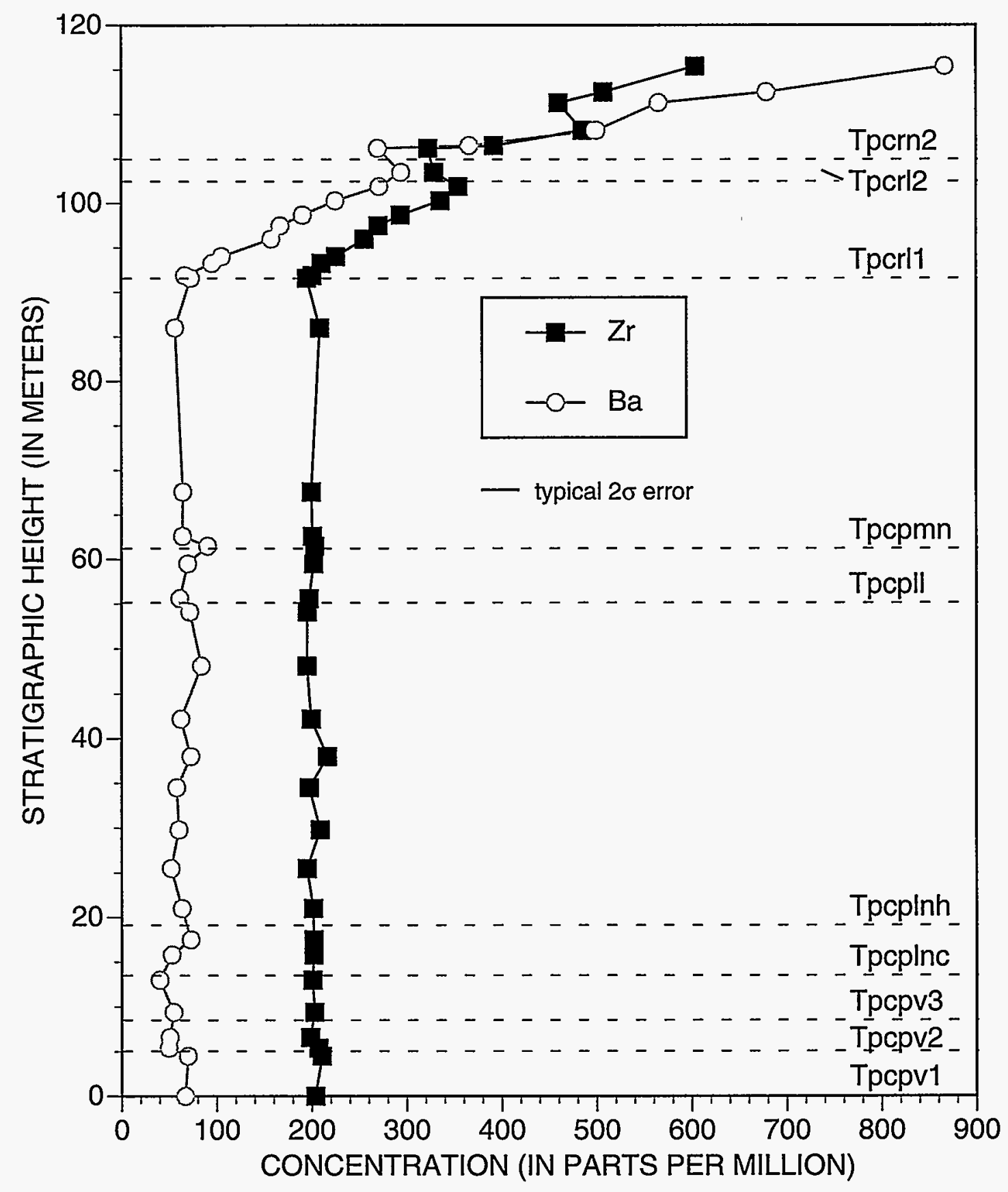

Figure 5. Zirconium and barium concentrations as a function of stratigraphic height in the Tiva Canyon Tuff from the Solitario Canyon reference section. Datum and abbreviations as in figure 3. 


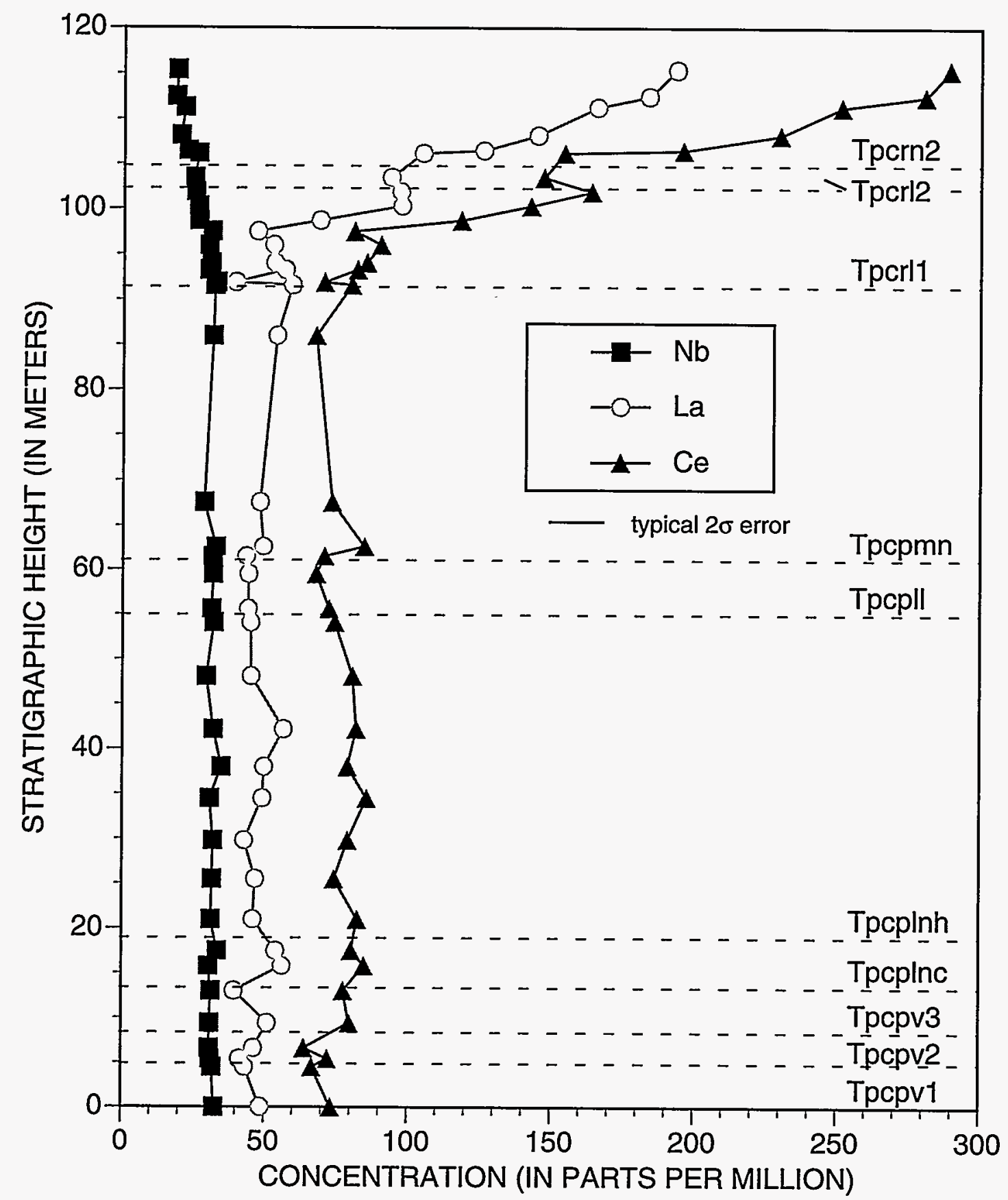

Figure 6. Niobium, lanthanum, and cerium concentrations as a function of stratigraphic height in the Tiva Canyon Tuff from the Solitario Canyon reference section. Datum and abbreviations as in figure 3. 


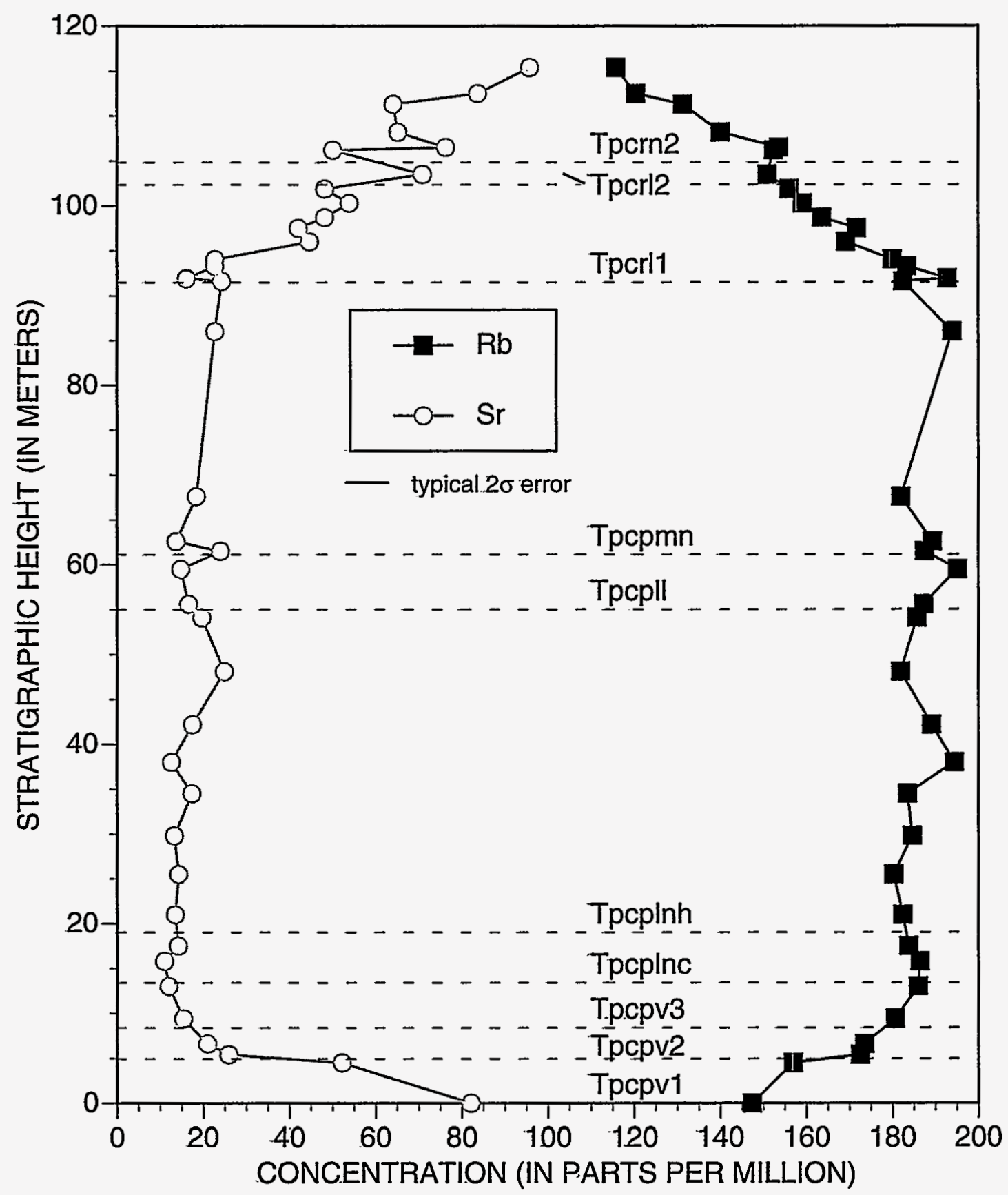

Figure 7. Rubidium and strontium concentrations as a function of stratigraphic height in the Tiva Canyon Tuff from the Solitario Canyon reference section. Note the variations in concentration near the base of the section. Datum and abbreviations as in figure 3. 


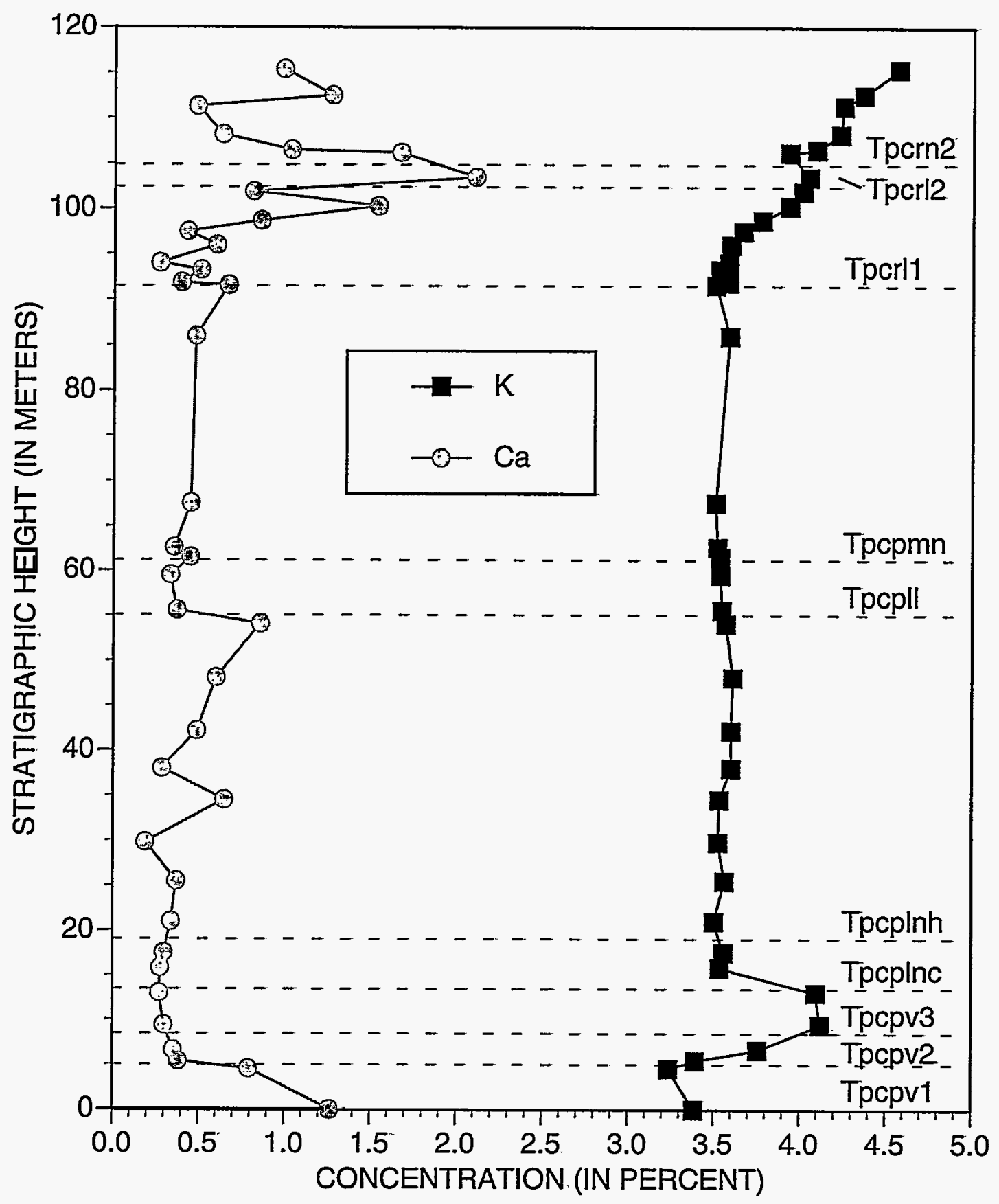

Figure 8. Potassium and calcium concentrations as a function of stratigraphic height in the Tiva Canyon Tuff from the Solitario Canyon reference section. Note the general scatter in calcium and the variations in both elements near the base of the unit. Datum and abbreviations as in figure 3 ; typical $2 \sigma$ errors are within the size of the symbols. 


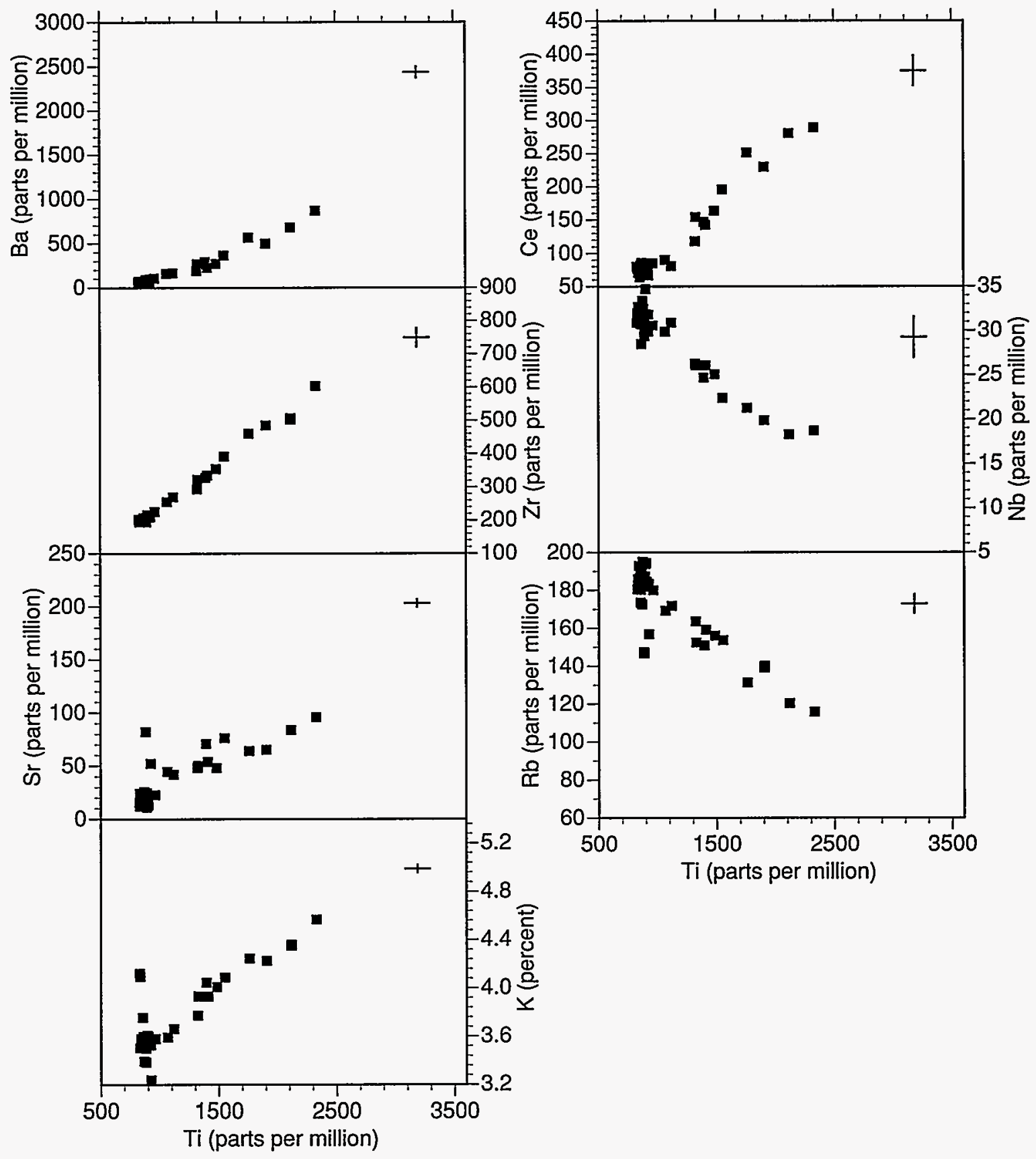

Figure 9. Variations of barium, cerium, zirconium, niobium, strontium, rubidium, and potassium concentrations as a function of titanium concentration in the Solitario Canyon reference section. The trends in these elements are typical of differentiation in magmatic systems. Note the greater scatter in rubidium, strontium, and potassium at low titanium concentrations. Typical $2 \sigma$ errors are shown by the crosses. 

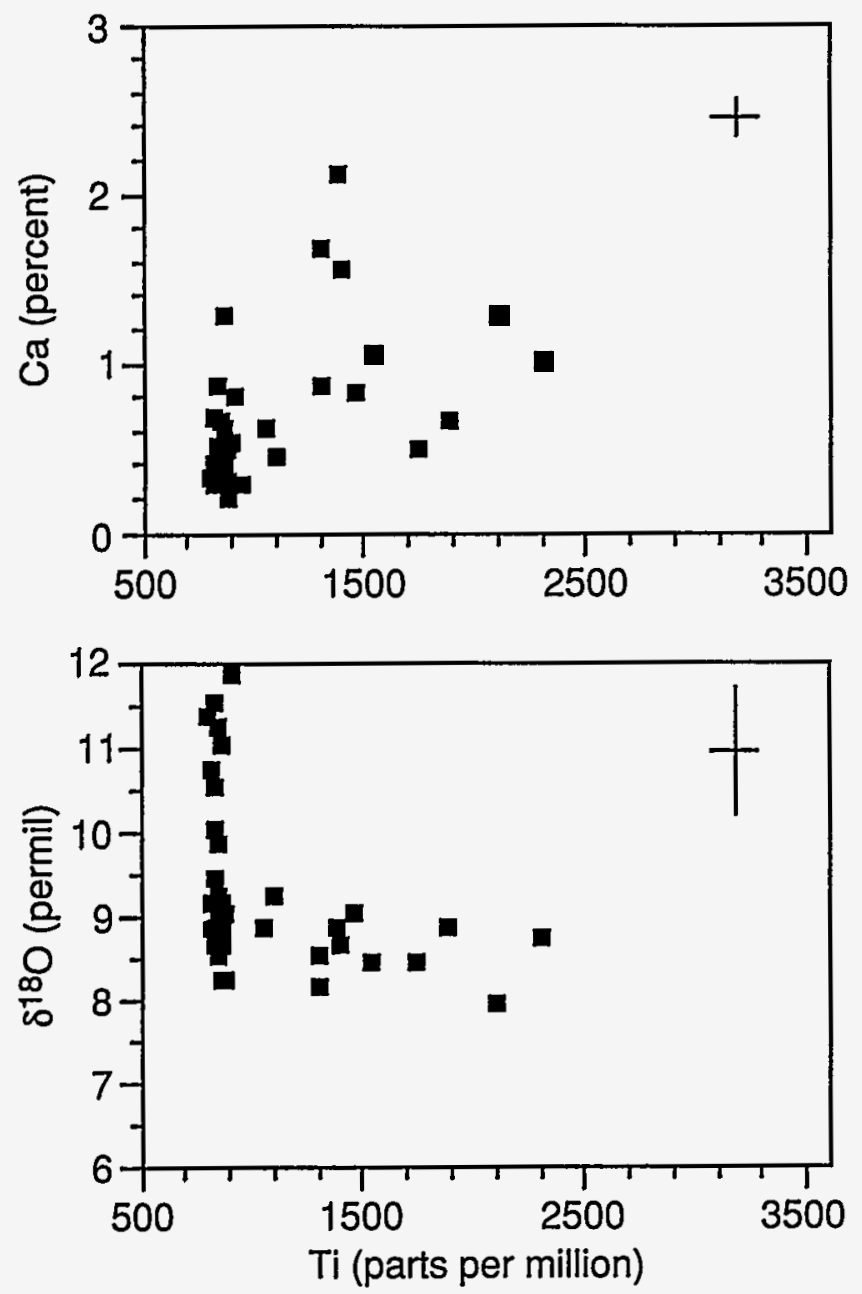

Flgure 10. Variation of calcium and $\delta^{18} \mathrm{O}$ as a function of titanium concentration in the Solitario Canyon reference section. Enrichments in ${ }^{18} \mathrm{O}$ relative to the estimated original magmatic values of +6 to $+8 \%$ are evident as well as significant variation in calcium contents; these trends are atypical of pristine igneous rocks. Typical $2 \sigma$ errors are shown by the crosses.

Yucca Mountain area and was formed via precipitation from meteoric waters at temperatures of about $25^{\circ} \mathrm{C}$ (Szabo and Kyser, 1990). Whole-rock $\delta^{18} \mathrm{O}$ values should not be affected by this process because the maximum amount of secondary carbonate (as estimated from both petrographic observations and the amounts of added calcium) is less than 5 percent, thereby resulting in a maximum increase of about $0.5 \%$. Furthermore, samples were selected to minimize the amount of secondary carbonate, and many samples were treated with acetic or hydrochloric acid to remove any small amount of carbonate present. The only other elements that would be affected by low-temperature fluids would be those that are easily mobilized by meteoric waters, such as rubidium, potassium, and strontium. The lack of correlations between potassium and titanium and between strontium and titanium is most pronounced in samples with the lowest potassium and strontium contents (fig. 9), as would be expected if these elements were affected by low-temperature fluids. On the other hand, rubidium contents are most variable in samples with the highest rubidium concentrations, which may simply indicate samples most affected by alteration because rubidium is so easily mobilized relative to most other elements. The effect of this lowtemperature alteration was both subtle and differential in that those components most likely to have been affected, namely $\delta^{18} \mathrm{O}$ values, calcium, rubidium, potassium, and strontium, do not correlate with each other.

The original $\delta^{18} \mathrm{O}$ values of high-silica rhyolite and quartz latite prior to any post-eruptive alteration can be ascertained from the isotopic composition of phenocrysts and the values reported for other ash-flow tuffs. Lipman and Friedman (1975) and Farmer and others (1991) reported $\delta^{18} \mathrm{O}$ values of +6.4 to +7.0 for sanidine phenocrysts in samples of the Tiva Canyon Tuff, and +6.8 to +8.1 for sanidine phenocrysts from the underlying Topopah Spring Tuff. These data imply magmatic $\delta^{18} \mathrm{O}$ values of about +7 to $+8 \%$ because the fractionation of oxygen isotopes between felsic silicate liquids and feldspar is small (Taylor and Epstein, 1962). Although the oxygen isotopic composition of the Tiva Canyon Tuff magma may have varied because of the irregular distribution of phenocrysts or interaction between the top of the magma and country rocks, other studies of genetically related ash-flow tuffs (Halliday and others, 1984; Taylor, 1991) indicate that such variations are usually less than $1 \%$, thereby constraining the original $\delta^{18} \mathrm{O}$ values of the high-silica rhyolite and quartz latite of the Solitario Canyon section to between +6 and $+8 \%$. In addition, Halliday and others (1984) reported $\delta^{18} \mathrm{O}$ values from +6.7 to +8.0 for sanidine phenocrysts from the Bishop Tuff, and McCulloch and others (1994) measured $\delta^{18} \mathrm{O}$ values from +6.1 to +7.0 for feldspar phenocrysts in rhyolites from the Taupo volcanic zone of New Zealand. A range of +6.3 to +7.3 for the $\delta^{18} \mathrm{O}$ values has been reported for feldspars in rhyolites from the Los Humeros volcanic center in Mexico (Ferriz and Mahood, 1987), and Taylor (1991) suggests values of +6 to +8 for the historic Obsidian Dome rhyolites from 
the Inyo volcanic chain in California. Only the Yellowstone rhyolites, for which $\delta^{18} \mathrm{O}$ values of quartz phenocrysts range from +0.7 to +7.7 (Hildreth and others, 1984), have significant variations in their phenocryst and whole-rock values. Such low $\delta^{18} \mathrm{O}$ values have been attributed to contributions from meteoric waters (Hildreth and others, 1984) or from hydrothermally altered country rocks (Taylor, 1986) added to the magma prior to eruption, processes that are clearly not recorded by the $\delta^{18} \mathrm{O}$ values of the tuffs from the Solitario Canyon section.

Only a few of the samples from the Solitario Canyon section have whole-rock $\delta^{18} \mathrm{O}$ values near those estimated for the original magma, and most are higher. In the few studies that report both phenocryst and whole-rock $\delta^{18} \mathrm{O}$ values of the same sample, the whole-rock values are usually near, but can be significantly higher or lower than, the original magmatic values estimated from the phenocrysts. For example, Stuckless and O'Neil (1973) reported significantly higher $\delta^{18} \mathrm{O}$ values (up to $+20.5 \%$ ) for whole-rock samples relative to phenocrysts of silicic volcanic rocks from the Superstition-Superior area in Arizona. They proposed that the high values resulted from lowtemperature alteration, including hydration of volcanic glass, a process that Taylor (1968) demonstrated could substantially increase the $\delta^{18} \mathrm{O}$ value of glass. In another study, three out of the six samples of the Bishop Tuff examined by Halliday and others (1984) have whole-rock $\delta^{18} \mathrm{O}$ values that are less than 1 permil higher than those of their sanidine phenocrysts. Whole-rock values in two samples are signifcantly higher, but lower in another, relative to their sanidine phenocrysts. Elevation of the whole-rock $\delta^{18} \mathrm{O}$ values was attributed to low-temperature exchange with ground waters, whereas ${ }^{18} \mathrm{O}$ depletions of the whole rock result from post-emplacement, hydrothermal alteration.

The conspicuous lack of any whole-rock $\delta^{18} \mathrm{O}$ values less than those of the original magma in the Solitario Canyon section indicates that these samples have not been affected by hydrothermal alteration. Moreover, the lack of correlation between $\delta^{18} \mathrm{O}$ values and titanium contents, the latter of which appear to faithfully record magmatic processes, indicates that variations in the oxygen isotopic composition of samples from the Solitario Canyon section are not magmatic. The $\delta^{18} \mathrm{O}$ values of samples from the Solitario Canyon section do not vary with the contents of any of the elements measured, including those elements that correlate poorly with titanium, such as calcium. However, $\delta^{18} \mathrm{O}$ values do correlate with certain petrographic features of the samples.

The highest $\delta^{18} \mathrm{O}$ values are in the samples from the base of the section (fig. 3 ) where the glass contents are highest. These glasses have petrographic characteristics typical of oxidation and hydration. Ross and Smith (1955), Friedman and Smith (1960), Taylor (1968), and Taylor (1991) have demonstrated that hydration of silicic volcanic glass by meteoric waters at low temperatures results in high $\delta^{18} \mathrm{O}$ values. This process is analogous to the formation of alteration minerals at low temperatures wherein the alteration product is enriched in ${ }^{18} \mathrm{O}$ by up to $30 \%$ relative to the water. Hydration, and the concomitant increase in $\delta^{18} \mathrm{O}$ value of the glass, is ubiquitous in all volcanic glasses because of their inherent instability in lowtemperature environments and is absent only in young (less than $1 \mathrm{Ma}$ ) volcanic glasses. Hydration of volcanic glass in the basal zone of the Solitario Canyon section via exchange with low-temperature meteoric water with $\delta^{18} \mathrm{O}$ values near $-12 \%$ (Benson and McKinley, 1985) could easily result in glass with $\delta^{18} \mathrm{O}$ values as high as $+11.8 \%$.

The lowest $\delta^{18} \mathrm{O}$ values are in nonlithophysal zones (fig. 3), although most of these are slightly elevated relative to primary magmatic values. These tuffs are totally devitrified and, therefore, were not altered by hydration but could have exsolved volatiles from the glass as it crystallized during cooling. Those samples with higher granophyric, spherulitic, and vapor-phase mineral components tend to be more ${ }^{18} \mathrm{O}$ rich than proximal samples where these components are less abundant (fig. 3). Thus, intervals of the Tiva Canyon Tuff in this section that were more affected by the fluids exsolving from the slowly cooling ash-flow have slightly more elevated $\delta^{18} \mathrm{O}$ values.

Exsolution of fluids and crystallization of the glass shards occur at subsolidus temperatures (less than $600^{\circ} \mathrm{C}$ ), and the fluids released are likely to have $\delta^{18} \mathrm{O}$ values equal to, or in excess of, those of the original glass. Quartz and feldspar precipitated at $600^{\circ} \mathrm{C}$ would be enriched in ${ }^{18} \mathrm{O}$ by 2 and $4 \%$, respectively, relative to the fluid, if the minerals and fluid were in isotopic equilibrium. Thus, recrystallization of slowly cooling tuffs, especially in the presence of deuteric fluids released during devitrification, could result in higher $\delta^{18} \mathrm{O}$ values in some samples. In support of this process, $\delta^{18} \mathrm{O}$ values of +11.1 and +12.5 have been measured in vapor-phase tridymite from the 
underlying Topopah Spring Tuff (Moscati and Whelan, U.S. Geological Survey, written commun., 1995). As with post-emplacement hydrothermal alteration, ground water trapped in the ash-flow and involved with recrystallization of the tuffs would have resulted in lower $\delta^{18} \mathrm{O}$ values of the whole-rock samples, instead of the relatively high values observed in this study. Only deuteric alteration would result in slightly elevated $\delta^{18} \mathrm{O}$ values relative to estimated original magmatic values.

Taylor (1991) reported only small differences in the $\delta^{18} \mathrm{O}$ values of obsidian, vesicular glass, devitrified glass; and pumice from the Obsidian Dome rhyolite in California. However, these rhyolitic tephra and ashflows, which were emplaced only 600 years ago, have hydrogen isotopic compositions and volatile contents that indicate that the hydrous melts had extensively degassed prior to and during eruption so that devitrifcation occurred after degassing. These results contrast with those from the tuffs of the Solitario Canyon section, in that the Tiva Canyon Tuff is significantly older, contains glass that has been hydrated, and was most likely degassed as a result of devitrification. Moreover, a few rhyolitic dike rocks from the Obsidian Dome area have slightly lower $\delta^{18} \mathrm{O}$ values than most of the other samples because of later hydrothermal alteration. The lack of low $\delta^{18} \mathrm{O}$ values from the Solitario Canyon section indicates that hydrothermal alteration has not affected these samples.

\section{UPPER CLIFF AND CAPROCK ZONES}

\section{Geology}

Samples of the upper cliff and caprock zones of the Tiva Canyon Tuff were collected from throughout the conceptual controlled area (fig. 2). The upper cliff zone was sampled preferentially, but limited exposure dictated that the stratigraphically higher caprock zone was sampled in many cases. Samples from the stratigraphically lower portions of the outcrops are equivalent to the uppermost part of the Solitario Canyon reference section (both upper cliff and caprock zones). Lithologically distinct samples within the caprock zone have higher phenocryst contents and are more reddish; they are less welded and therefore tend to have a higher secondary carbonate content. These samples are also characterized by barium contents in excess of 1,500 ppm and represent the quartz latite (Flood and others, 1989) within the caprock zone. For the purposes of the following discussion, we refer to these lithologically distinct samples as the caprock zone. These samples are within the upper portion of the caprock zone as defined by Scott and Bonk (1984).

\section{Oxygen Isotope and Chemical Compositions}

Delta ${ }^{18} \mathrm{O}$ values for samples from the upper cliff and caprock zones range from +6.9 to +11.8 (table 3 ), virtually identical to the range of values from the Solitario Canyon section. Most of these $\delta^{18} \mathrm{O}$ values are higher than estimated original magmatic values of approximately +6 to +8 , and none are less. There is no relation between $\delta^{18} \mathrm{O}$ values and proximity to known faults in the area or other geologic features; there is little spatial regularity to the oxygen isotope compositions in general (fig. 11).

The concentrations of barium, cerium, zirconium, niobium, strontium, rubidium, potassium, and thorium vary regularly with titanium contents in the upper cliff and caprock zone samples (tables 4, 5, and 6; fig. 12), overlapping and exceeding the contents of these elements in samples from the Solitario Canyon section. The trends with titanium contents for barium, cerium, and potassium in the caprock zone samples are distinct from those from the upper cliff zone, whereas the other elemental trends in the upper cliff zone samples overlap and are continuous with those from the caprock zone (fig. 12). The higher titanium contents of samples from the caprock zone relative to those from the upper cliff zone reflect a higher phenocryst content and, by inference, a deeper and less siliceous portion of the magma chamber. The trends in these elements are virtually identical to those in samples of the Tiva Canyon Tuff from the Solitario Canyon section and in ash-flow units in general and are emblematic of the magmatic processes that operate in these systems. The rare earth elements also show typical magmatic trends (figs. 12 and 13), with the upper cliff samples showing a relative depletion in europium, probably resulting from crystal fractionation of plagioclase phenocrysts in the high-silica rhyolite.

Calcium, sodium, iron, and uranium contents and $\delta^{18} \mathrm{O}$ values for samples of the upper cliff and caprock zones do not correlate as well as other 
Table 3. Map coordinates, sample numbers, and oxygen isotope compositions of the Tiva Canyon Tuff

[Sample site number plotted on figure 2; Universal Transverse Mercator coordinates in Zone 11]

\begin{tabular}{|c|c|c|c|c|}
\hline $\begin{array}{l}\text { Sample site } \\
\text { number }\end{array}$ & $\begin{array}{l}\text { Sample } \\
\text { number }\end{array}$ & UTM easting & UTM northing & $\begin{array}{l}\delta^{18} 0 \\
(\%)\end{array}$ \\
\hline 1 & MR-1000 & 547841 & 4083341 & 10.1 \\
\hline 2 & MR-1001 & 547718 & 4083217 & 8.6 \\
\hline 3 & MR-1002 & 547842 & 4083279 & 9.2 \\
\hline 4 & MR-1003 & 547647 & 4082724 & 8.4 \\
\hline 5 & MR-1004 & 548291 & 4082604 & 8.5 \\
\hline 6 & MR-1005 & 548409 & 4087905 & 8.1 \\
\hline 7 & MR-1006 & 547973 & 4081924 & 8.2 \\
\hline 8 & MR-1007 & 548073 & 4081678 & 9.1 \\
\hline 9 & MR-1008 & 548223 & 4081433 & 7.7 \\
\hline 10 & MR-1009 & 548323 & 4081310 & 7.6 \\
\hline 11 & MR-1010 & 548616 & 4082051 & 7.4 \\
\hline 12 & MR-1011 & 548766 & 4081713 & 7.2 \\
\hline 13 & MR-1012 & 549114 & 4081499 & 8.9 \\
\hline 14 & MR-1013 & 549067 & 4081068 & 8.8 \\
\hline 15 & MR-1014 & 550478 & 4081107 & 6.9 \\
\hline 16 & MR-1015 & 550402 & 4081384 & 8.8 \\
\hline 17 & MR-1016 & 549905 & 4081751 & 8.6 \\
\hline 18 & MR-1017 & 549607 & 4081903 & 9.3 \\
\hline 19 & MR-1018 & 549432 & 4082148 & 8.2 \\
\hline 20 & MR-1019 & 549782 & 4081657 & 8.2 \\
\hline 21 & MR-1020 & 550006 & 4081351 & 7.6 \\
\hline 22 & MR-1021 & 549339 & 4081131 & 8.0 \\
\hline 23 & MR-1022 & 549514 & 4080762 & 8.7 \\
\hline 24 & MR-1023 & 549268 & 4080576 & 8.0 \\
\hline 25 & MR-1024 & 549368 & 4080361 & 8.5 \\
\hline 26 & MR-1025 & 549618 & 4079962 & 8.4 \\
\hline 27 & MR-1026 & 549917 & 4079686 & 8.4 \\
\hline 28 & MR-1027 & 553712 & 4078723 & 8.4 \\
\hline 29 & MR-1028 & 553636 & 4078846 & 8.1 \\
\hline 30 & MR-1029 & 553266 & 4078659 & 8.8 \\
\hline 31 & MR-1030 & 553068 & 4078657 & 9.4 \\
\hline 32 & MR-1031 & 553046 & 4078226 & 9.2 \\
\hline 33 & MR-1032 & 553294 & 4078227 & 8.6 \\
\hline 34 & MR-1033 & 553160 & 4079798 & 8.4 \\
\hline 35 & MR-1034 & 553013 & 4079551 & 9.2 \\
\hline 36 & MR-1035 & 553336 & 4079368 & 9.1 \\
\hline 37 & MR-1036 & 553389 & 4078813 & 9.2 \\
\hline 38 & MR-1037 & 552918 & 4078965 & 9.2 \\
\hline 39 & MR-1038 & 550094 & 4078978 & 7.7 \\
\hline 40 & MR-1039 & 549698 & 4079038 & 8.5 \\
\hline 41 & MR-1040 & 549721 & 4079284 & 9.2 \\
\hline 42 & MR-104I & 550171 & 4078640 & 8.2 \\
\hline 43 & MR-1042 & 550319 & 4078764 & 8.6 \\
\hline 44 & MR-1043 & 550221 & 4078517 & 8.7 \\
\hline
\end{tabular}


Table 3. Map coordinates, sample numbers, and oxygen isotope compositions of the Tiva Canyon Tuff-Continued

[Sample site number plotted on figure 2; Universal Transverse Mercator coordinates in Zone 11]

\begin{tabular}{|c|c|c|c|c|}
\hline $\begin{array}{c}\text { Sample site } \\
\text { number }\end{array}$ & $\begin{array}{l}\text { Sample } \\
\text { number }\end{array}$ & UTM easting & UTM northing & $\begin{array}{l}\delta^{18} 0 \\
(\% \circ)\end{array}$ \\
\hline 45 & MR-1044 & 550247 & 4078301 & 8.5 \\
\hline 46 & MR-1045 & 547654 & 4081460 & 9.4 \\
\hline 47 & MR-1046 & 547853 & 4081184 & 8.6 \\
\hline 48 & MR-1047 & 548104 & 4080662 & 9.4 \\
\hline 50 & MR-1049 & 552220 & 4075632 & 10.8 \\
\hline 51 & MR-1050 & 552169 & 4075909 & 10.4 \\
\hline 52 & MR-1051 & 551009 & 4075163 & 9.7 \\
\hline 53 & MR-1052 & 551235 & 4074609 & 9.0 \\
\hline 54 & MR-1053 & 551457 & 4074703 & 10.0 \\
\hline 55 & MR-1054 & 551629 & 4075043 & 9.3 \\
\hline 56 & MR-1055 & 552804 & 4077300 & 9.5 \\
\hline 57 & MR-1056 & 552756 & 4076991 & 11.8 \\
\hline 58 & MR-1057 & 552635 & 4076683 & 10.3 \\
\hline 59 & MR-1058 & 552339 & 4076373 & 9.4 \\
\hline 60 & MR-1059 & 552416 & 4076034 & 8.4 \\
\hline 61 & MR-1060 & 552639 & 4076005 & 9.8 \\
\hline 62 & MR-1061 & 552763 & 4076005 & 8.8 \\
\hline 63 & MR-1062 & 548329 & 4080262 & 9.6 \\
\hline 64 & MR-1063 & 548477 & 4080325 & 7.1 \\
\hline 65 & MR-1064 & 549597 & 4079284 & 7.6 \\
\hline 66 & MR-1065 & 549347 & 4079683 & 7.1 \\
\hline 67 & MR-1066 & 549123 & 4079928 & 8.3 \\
\hline 68 & MR-1067 & 548109 & 4079676 & 7.9 \\
\hline 69 & MR-1068 & 548482 & 4079524 & 8.8 \\
\hline 70 & MR-1069 & 548610 & 4078692 & 8.8 \\
\hline 71 & MR-1070 & 548885 & 4078324 & 9.2 \\
\hline 72 & MR-1071 & 548273 & 4077057 & 9.8 \\
\hline 73 & MR-1072 & 548274 & 4076811 & 8.4 \\
\hline 74 & MR-1073 & 548671 & 4076782 & 9.5 \\
\hline 75 & MR-1074 & 548846 & 4076475 & 8.3 \\
\hline 76 & MR-1075 & 549194 & 4076231 & 9.4 \\
\hline 77 & MR-1076 & 549415 & 4076602 & 9.2 \\
\hline 78 & MR-1077 & 550008 & 4076852 & 10.2 \\
\hline 79 & MR-1078 & 549808 & 4077159 & 9.5 \\
\hline 80 & MR-1079 & 550259 & 4076329 & 8.2 \\
\hline 81 & MR-1200 & 548116 & 4074098 & 9.3 \\
\hline 82 & MR-1201 & 548139 & 4074499 & 8.9 \\
\hline 83 & MR-1202 & 547570 & 4074249 & 9.6 \\
\hline 84 & MR-1203 & 547494 & 4074557 & 9.7 \\
\hline 85 & MR-1204 & 547567 & 4074896 & 9.5 \\
\hline 86 & MR-1205 & 547614 & 4075328 & 9.6 \\
\hline 87 & MR-1206 & 547563 & 4075513 & 10.7 \\
\hline 88 & MR-1207 & 547358 & 4076713 & 9.2 \\
\hline 89 & MR-1208 & 547529 & 4077269 & 8.1 \\
\hline
\end{tabular}


Table 3. Map coordinates, sample numbers, and oxygen isotope compositions of the Tiva Canyon Tuff-Continued

[Sample site number plotted on figure 2; Universal Transverse Mercator coordinates in Zone 11]

\begin{tabular}{|c|c|c|c|c|}
\hline $\begin{array}{c}\text { Samplesite } \\
\text { number }\end{array}$ & $\begin{array}{l}\text { Sample } \\
\text { number }\end{array}$ & UTM easting & UTM northing & $\begin{array}{c}\delta^{18} 0 \\
(\% \circ)\end{array}$ \\
\hline 90 & MR-1209 & 547527 & 4077485 & 9.3 \\
\hline 91 & MR- 1210 & 547648 & 4078071 & 8.9 \\
\hline 92 & MR-1211 & 547645 & 4078533 & 7.5 \\
\hline 93 & MR-1212 & 547643 & 4078995 & 9.5 \\
\hline 94 & MR-1213 & 547616 & 4079365 & 7.7 \\
\hline 95 & MR-1214 & 547785 & 4080167 & 8.1 \\
\hline 96 & MR-1215 & 547513 & 4080135 & 8.2 \\
\hline 97 & MR-1216 & 547585 & 4080443 & 8.1 \\
\hline 98 & MR-1217 & 548777 & 4075519 & 9.3 \\
\hline 99 & MR-1218 & 548877 & 4075428 & 8.8 \\
\hline 100 & MR-1219 & 548952 & 4075243 & 9.0 \\
\hline 101 & MR-1220 & 548906 & 4074627 & 9.7 \\
\hline 102 & MR-1221 & 549005 & 4074720 & 8.9 \\
\hline 103 & MR-1222 & 549745 & 4075279 & 9.2 \\
\hline 104 & MR-1223 & 549719 & 4075402 & 9.7 \\
\hline 105 & MR-1224 & 550065 & 4075558 & 10.0 \\
\hline 106 & MR-1225 & 550042 & 4075311 & 10.6 \\
\hline 107 & MR-1226 & 550018 & 4075188 & 8.8 \\
\hline 108 & MR-1227 & 549995 & 4074879 & 9.4 \\
\hline 110 & MR-1229 & 549744 & 4075309 & 10.2 \\
\hline 111 & MR-1230 & 549356 & 4073920 & 10.9 \\
\hline 112 & MR-1231 & 549206 & 4074197 & 8.5 \\
\hline 113 & MR-1232 & 549308 & 4073612 & 8.8 \\
\hline 114 & MR-1233 & 549824 & 4074324 & 10.6 \\
\hline 115 & MR-1234 & 549924 & 4074324 & 9.9 \\
\hline 116 & MR-1235 & 550026 & 4073770 & 8.5 \\
\hline 117 & MR-1236 & 551417 & 4073224 & 9.8 \\
\hline 118 & MR-1237 & 551167 & 4073592 & 9.7 \\
\hline 119 & MR-1238 & 551115 & 4073962 & 8.6 \\
\hline 120 & MR-1239 & 550819 & 4073683 & 8.3 \\
\hline 121 & MR-1240 & 550893 & 4078028 & 7.7 \\
\hline 122 & MR-1241 & 550889 & 4078552 & 8.6 \\
\hline 123 & MR-1242 & 550937 & 4078798 & 8.3 \\
\hline 124 & MR-1243 & 550899 & 4076949 & 9.0 \\
\hline 125 & MR-1244 & 550828 & 4076363 & 10.4 \\
\hline 126 & MR-1245 & 550907 & 4075686 & 9.3 \\
\hline 127 & MR-1246 & 550609 & 4075653 & 7.5 \\
\hline 128 & MR-1300 & 547410 & 4080781 & 9.2 \\
\hline 129 & MR-1301 & 547236 & 4080934 & 8.7 \\
\hline 130 & MR-1302 & 546936 & 4081364 & 8.1 \\
\hline 131 & MR-1303 & 546759 & 4082164 & 7.8 \\
\hline 132 & MR-1304 & 546433 & 4082809 & 8.7 \\
\hline 133 & MR-1305 & 546484 & 4082563 & 8.6 \\
\hline 134 & MR-1306 & 546389 & 4081946 & 8.9 \\
\hline
\end{tabular}


Table 3. Map coordinates, sample numbers, and oxygen isotope compositions of the Tiva Canyon Tuff-Continued

[Sample site number plotted on figure 2; Universal Transverse Mercator coordinates in Zone 11]

\begin{tabular}{ccccc}
\hline $\begin{array}{c}\text { Samplesite } \\
\text { number }\end{array}$ & $\begin{array}{c}\text { Sample } \\
\text { number }\end{array}$ & UTM easting & UTM northing & $\begin{array}{c}\delta^{18} \mathrm{O} \\
(\%)\end{array}$ \\
\hline 135 & MR-1307 & 546341 & 4081576 & 8.8 \\
136 & MR-1308 & 546293 & 4081391 & 9.0 \\
137 & MR-1309 & 546765 & 4081086 & 9.0 \\
138 & MR-1310 & 547163 & 4080687 & 7.8 \\
139 & MR-1311 & 547115 & 4080348 & 8.7 \\
140 & MR-1312 & 545491 & 4078521 & 9.1 \\
141 & MR-1313 & 545514 & 4078799 & 9.7 \\
142 & MR-1314 & 545611 & 4079261 & 9.5 \\
143 & MR-1315 & 545807 & 4079601 & 9.1 \\
144 & MR-1316 & 545979 & 4079910 & 8.8 \\
145 & MR-1317 & 546124 & 4080466 & 9.0 \\
146 & MR-1318 & 547044 & 4079762 & 9.2 \\
147 & MR-1319 & 546875 & 4079083 & 9.7 \\
148 & MR-1320 & 546801 & 4078898 & 9.2 \\
149 & MR-1321 & 546680 & 4078528 & 8.2 \\
150 & MR-1322 & 546584 & 4077849 & 7.7 \\
151 & MR-1323 & 545321 & 4077842 & 9.8 \\
152 & MR-1324 & 545149 & 4077533 & 10.0 \\
153 & MR-1325 & 545322 & 4077596 & 8.7 \\
154 & MR-1326 & 545618 & 4077967 & 10.4 \\
155 & MR-1327 & 545747 & 4076982 & 9.3 \\
156 & MR-1328 & 545674 & 4076704 & 9.4 \\
157 & MR-1329 & 545726 & 4076273 & 10.3 \\
158 & MR-1330 & 545945 & 4077044 & 8.3 \\
159 & MR-1331 & 545916 & 4077784 & 7.8 \\
\hline & & & &
\end{tabular}




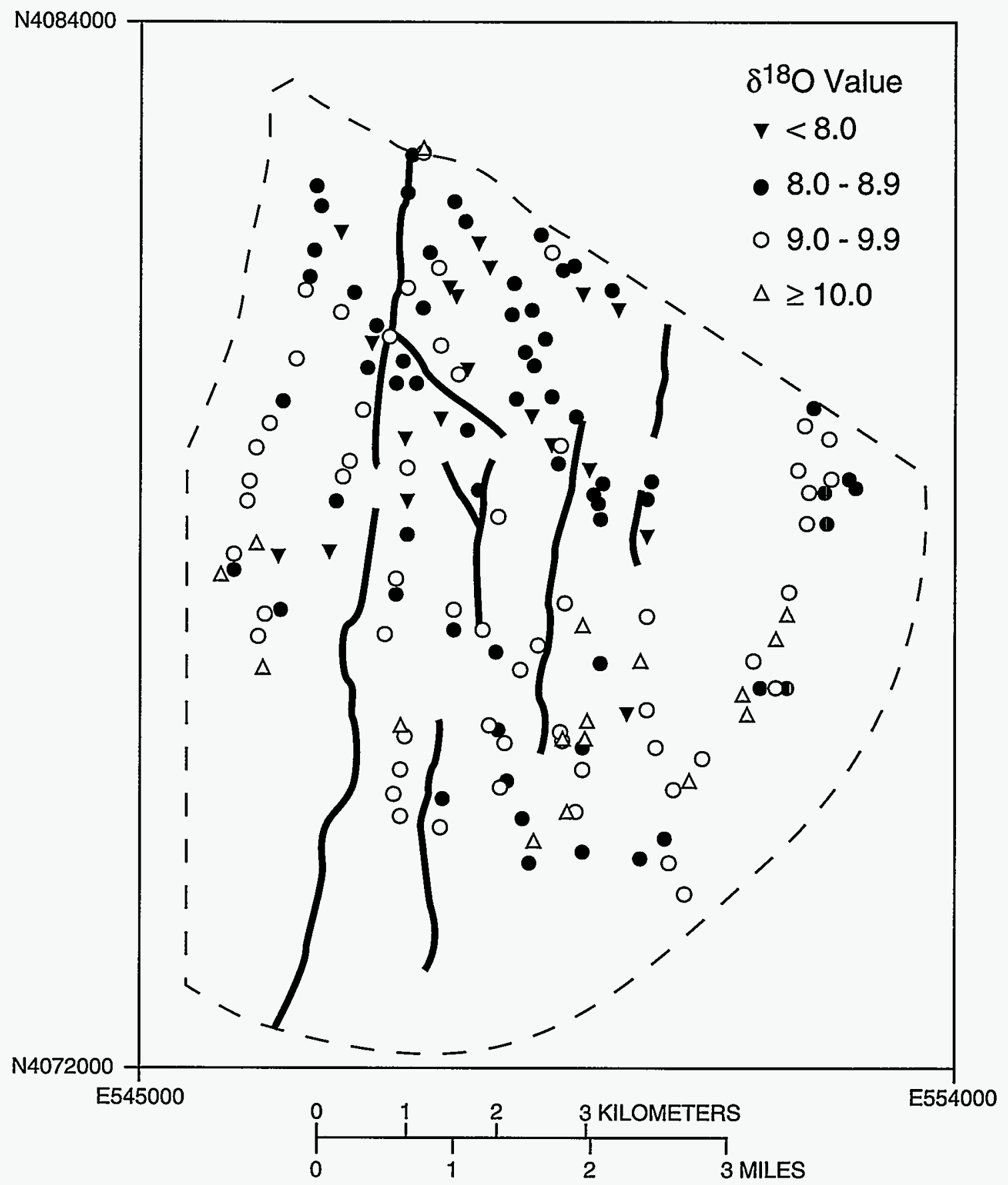

Figure 11. Conceptual controlled area and $\delta^{18} \mathrm{O}$ values for the upper cliff and caprock zones. Areas of high $\delta^{18} \mathrm{O}$ indicate more post-eruptive low-temperature alteration and lithophysal crystallization of silica. Fault traces generalized from O'Neill and others (1992). 
Table 4. Chemistry of major elements

[In percent by weight]

\begin{tabular}{|c|c|c|c|c|c|}
\hline $\begin{array}{c}\text { Sample site } \\
\text { number }\end{array}$ & $\mathrm{Na}^{1}$ & $\mathrm{~K}^{2}$ & $\mathrm{Ca}^{2}$ & $\pi^{2}$ & $\mathrm{Fe}^{1}$ \\
\hline 1 & 3.06 & 4.22 & 0.53 & 0.23 & 1.23 \\
\hline 2 & 3.04 & 4.31 & 0.89 & 0.28 & 1.33 \\
\hline 3 & 3.06 & 4.25 & 1.26 & 0.24 & 1.28 \\
\hline 4 & 3.07 & 4.22 & 1.09 & 0.25 & 1.33 \\
\hline 5 & 3.16 & 4.29 & 0.71 & 0.24 & 1.26 \\
\hline 6 & 3.01 & 4.41 & 0.69 & 0.26 & 1.24 \\
\hline 7 & 3.00 & 4.56 & 1.15 & 0.26 & 1.28 \\
\hline 8 & 2.93 & 4.35 & 1.05 & 0.26 & 1.22 \\
\hline 9 & 3.08 & 4.36 & 0.72 & 0.26 & 1.33 \\
\hline 10 & 3.08 & 4.30 & 0.87 & 0.23 & 1.30 \\
\hline 11 & 3.00 & 4.48 & 1.21 & 0.28 & 1.29 \\
\hline 12 & 2.88 & 4.20 & 0.80 & 0.26 & 1.27 \\
\hline 13 & 2.94 & 4.93 & 2.17 & 0.33 & 1.50 \\
\hline 14 & 3.02 & 4.32 & 1.29 & 0.24 & 1.21 \\
\hline 15 & 3.15 & 4.57 & 1.23 & 0.21 & 1.28 \\
\hline 16 & 3.04 & 4.23 & 0.79 & 0.23 & 1.36 \\
\hline 17 & 2.80 & 4.18 & 0.94 & 0.21 & 1.15 \\
\hline 18 & 2.93 & 4.19 & 0.72 & 0.23 & 1.22 \\
\hline 19 & 3.00 & 4.97 & 1.57 & 0.30 & 1.40 \\
\hline 20 & 3.13 & 4.31 & 0.85 & 0.25 & 1.28 \\
\hline 21 & 3.22 & 5.16 & 0.95 & 0.32 & 1.58 \\
\hline 22 & 3.14 & 4.31 & 0.92 & 0.25 & 1.33 \\
\hline 23 & 3.39 & 4.75 & 1.15 & 0.24 & 1.44 \\
\hline 24 & 3.38 & 5.00 & 1.17 & 0.30 & 1.65 \\
\hline 25 & 3.18 & 4.98 & 2.57 & 0.28 & 1.41 \\
\hline 26 & 3.15 & 4.85 & 1.37 & 0.25 & 1.34 \\
\hline 27 & 3.36 & 4.68 & 0.73 & 0.23 & 1.47 \\
\hline 28 & 3.17 & 4.72 & 0.63 & 0.24 & 1.37 \\
\hline 29 & 3.32 & 4.84 & 1.10 & 0.27 & 1.55 \\
\hline 30 & 3.19 & 4.41 & 0.78 & 0.20 & 1.17 \\
\hline 31 & 3.13 & 4.46 & 1.77 & 0.21 & 1.31 \\
\hline 32 & 3.36 & 4.72 & 0.54 & 0.22 & 1.40 \\
\hline 33 & 3.48 & 4.68 & 1.19 & 0.24 & 1.49 \\
\hline 34 & 3.56 & 4.53 & 0.57 & 0.21 & 1.41 \\
\hline 35 & 3.29 & 4.69 & 3.32 & 0.23 & 1.45 \\
\hline 36 & 3.54 & 4.38 & 0.49 & 0.19 & 1.28 \\
\hline 37 & 3.42 & 4.36 & 0.72 & 0.19 & 1.26 \\
\hline 38 & 3.37 & 4.58 & 0.96 & 0.23 & 1.45 \\
\hline 39 & 3.28 & 4.10 & 0.42 & 0.17 & 1.07 \\
\hline 40 & 3.53 & 4.81 & 0.63 & 0.24 & 1.56 \\
\hline 41 & 3.43 & 4.60 & 0.86 & 0.22 & 1.45 \\
\hline 42 & 3.66 & 4.81 & 0.66 & 0.25 & 1.60 \\
\hline 43 & 3.49 & 4.84 & 1.19 & 0.23 & 1.51 \\
\hline 44 & 3.27 & 4.51 & 1.77 & 0.19 & 1.24 \\
\hline
\end{tabular}


Table 4. Chemistry of major elements-Continued [In percent by weight]

\begin{tabular}{cccccc}
\hline $\begin{array}{c}\text { Sample slte } \\
\text { number }\end{array}$ & $\mathrm{Na}^{1}$ & $\mathrm{~K}^{2}$ & $\mathrm{Ca}^{2}$ & $\mathrm{~T}^{2}$ & $\mathrm{Fe}^{\mathbf{1}}$ \\
\hline 45 & 3.33 & 4.33 & 0.53 & 0.19 & 1.24 \\
46 & 3.47 & 4.66 & 0.69 & 0.23 & 1.37 \\
47 & 3.45 & 4.35 & 0.51 & 0.20 & 1.32 \\
48 & 3.82 & 4.93 & 0.76 & 0.30 & 1.78 \\
50 & 3.57 & 4.49 & 0.50 & 0.20 & 1.28 \\
51 & 3.05 & 3.71 & 1.12 & 0.08 & 0.70 \\
52 & 3.35 & 4.52 & 0.91 & 0.21 & 1.34 \\
53 & 3.27 & 4.56 & 1.33 & 0.21 & 1.34 \\
54 & 2.96 & 3.72 & 1.99 & 0.09 & 0.74 \\
55 & 3.24 & 4.63 & 2.47 & 0.22 & 1.27 \\
56 & 3.43 & 3.99 & 0.49 & 0.15 & 1.16 \\
57 & 3.34 & 4.28 & 0.90 & 0.18 & 1.27 \\
58 & 3.58 & 4.31 & 0.46 & 0.18 & 1.25 \\
59 & 3.70 & 4.60 & 0.58 & 0.21 & 1.42 \\
60 & 3.64 & 4.80 & 0.56 & 0.23 & 1.41 \\
61 & 3.44 & 4.41 & 0.57 & 0.20 & 1.34 \\
62 & 3.46 & 4.24 & 0.41 & 0.18 & 1.22 \\
63 & 3.25 & 3.82 & 0.35 & 0.12 & 0.99 \\
64 & 3.66 & 4.65 & 0.56 & 0.22 & 1.55 \\
65 & 3.47 & 4.63 & 1.62 & 0.22 & 1.36 \\
66 & 3.70 & 4.76 & 0.69 & 0.25 & 1.52 \\
67 & 3.41 & 4.65 & 0.60 & 0.22 & 1.43 \\
68 & 3.16 & 4.65 & 0.80 & 0.24 & 1.36 \\
69 & 3.36 & 4.36 & 0.54 & 0.20 & 1.23 \\
70 & 3.33 & 4.29 & 0.48 & 0.17 & 1.16 \\
71 & 3.26 & 4.06 & 0.86 & 0.16 & 1.07 \\
72 & 3.22 & 3.58 & 0.24 & 0.09 & 0.77 \\
73 & 3.49 & 4.23 & 0.44 & 0.18 & 1.32 \\
74 & 3.36 & 4.55 & 0.72 & 0.22 & 1.38 \\
75 & 3.14 & 3.92 & 1.33 & 0.13 & 1.01 \\
76 & 3.66 & 4.41 & 0.50 & 0.19 & 1.29 \\
77 & 3.36 & 4.45 & 0.52 & 0.20 & 1.30 \\
78 & 3.28 & 4.34 & 0.71 & 0.19 & 1.25 \\
79 & 3.34 & 4.33 & 0.43 & 0.19 & 1.31 \\
80 & 3.33 & 4.21 & 0.63 & 0.18 & 1.28 \\
81 & 3.36 & 4.28 & 0.78 & 0.19 & 1.31 \\
82 & 3.59 & 4.36 & 0.49 & 0.19 & 1.37 \\
83 & 3.17 & 3.99 & 1.68 & 0.14 & 0.99 \\
84 & 3.37 & 4.31 & 1.11 & 0.18 & 1.20 \\
85 & 3.10 & 4.50 & 2.17 & 0.20 & 1.15 \\
86 & 3.07 & 3.73 & 0.53 & 0.13 & 0.89 \\
87 & 3.16 & 4.06 & 1.73 & 0.15 & 1.11 \\
88 & 3.14 & 3.97 & 1.86 & 0.13 & 1.01 \\
89 & 3.31 & 3.92 & 0.42 & 0.15 & 1.06 \\
90 & 3.59 & 4.23 & 0.53 & 0.18 & 1.28 \\
& & & & &
\end{tabular}


Table 4. Chemistry of major elements-Continued [In percent by weight]

\begin{tabular}{|c|c|c|c|c|c|}
\hline $\begin{array}{c}\text { Sample site } \\
\text { number }\end{array}$ & $\mathrm{Na}^{1}$ & $\mathrm{k}^{2}$ & $\mathrm{Ca}^{2}$ & $\pi^{2}$ & $\mathrm{Fe}^{1}$ \\
\hline 91 & 3.29 & 4.08 & 1.06 & 0.16 & 1.23 \\
\hline 92 & 3.47 & 4.23 & 0.59 & 0.17 & 1.28 \\
\hline 93 & 3.44 & 4.48 & 1.74 & 0.22 & 1.42 \\
\hline 94 & 3.54 & 4.71 & 0.59 & 0.24 & 1.50 \\
\hline 95 & 3.58 & 4.60 & 0.84 & 0.23 & 1.56 \\
\hline 96 & 3.59 & 4.62 & 0.87 & 0.24 & 1.62 \\
\hline 97 & 3.66 & 4.63 & 0.84 & 0.23 & 1.55 \\
\hline 98 & 3.01 & 3.69 & 0.87 & 0.10 & 0.88 \\
\hline 99 & 3.31 & 4.32 & 0.66 & 0.17 & 1.18 \\
\hline 100 & 3.46 & 4.49 & 0.57 & 0.20 & 1.27 \\
\hline 101 & 3.41 & 4.19 & 0.49 & 0.18 & 1.28 \\
\hline 102 & 3.22 & 4.16 & 1.28 & 0.17 & 1.20 \\
\hline 103 & 3.19 & 3.54 & 0.32 & 0.11 & 0.87 \\
\hline 104 & 3.02 & 3.61 & 1.00 & 0.10 & 0.84 \\
\hline 105 & 3.18 & 3.75 & 0.27 & 0.12 & 0.95 \\
\hline 106 & 3.06 & 3.76 & 1.07 & 0.12 & 0.85 \\
\hline 107 & 3.19 & 3.85 & 2.55 & 0.13 & 0.96 \\
\hline 108 & 3.34 & 3.73 & 0.34 & 0.11 & 0.96 \\
\hline 110 & 3.08 & 3.83 & 0.66 & 0.12 & 0.85 \\
\hline 111 & 3.41 & 4.27 & 0.48 & 0.19 & 1.23 \\
\hline 112 & 3.29 & 4.34 & 1.00 & 0.19 & 1.26 \\
\hline 113 & 3.29 & 4.06 & 0.50 & 0.18 & 1.23 \\
\hline 114 & 3.16 & 4.44 & 1.37 & 0.13 & 0.98 \\
\hline 115 & 3.34 & 3.97 & 1.36 & 0.14 & 1.10 \\
\hline 116 & 3.48 & 4.54 & 0.85 & 0.20 & 1.26 \\
\hline 117 & 3.21 & 3.81 & 0.31 & 0.13 & 0.95 \\
\hline 118 & 3.35 & 4.52 & 2.18 & 0.19 & 1.19 \\
\hline 119 & 3.14 & 3.74 & 0.29 & 0.12 & 0.92 \\
\hline 120 & 3.50 & 4.37 & 0.77 & 0.18 & 1.22 \\
\hline 121 & 3.46 & 4.45 & 0.48 & 0.19 & 1.33 \\
\hline 122 & 3.50 & 3.97 & 0.32 & 0.13 & 1.09 \\
\hline 123 & 3.58 & 4.41 & 0.57 & 0.22 & 1.42 \\
\hline 124 & 2.94 & 3.64 & 0.55 & 0.11 & 0.89 \\
\hline 125 & 3.06 & 3.72 & 0.51 & 0.12 & 0.84 \\
\hline 126 & 2.98 & 3.59 & 0.42 & 0.11 & 0.81 \\
\hline 127 & 2.92 & 4.12 & 2.85 & 0.14 & 0.97 \\
\hline 128 & 3.16 & 3.99 & 0.42 & 0.15 & 1.12 \\
\hline 129 & 3.15 & 4.16 & 0.38 & 0.17 & 1.12 \\
\hline 130 & 3.23 & 4.36 & 0.48 & 0.19 & 1.21 \\
\hline 131 & 3.10 & 4.16 & 0.54 & 0.18 & 1.11 \\
\hline 132 & 3.28 & 4.86 & 1.50 & 0.35 & 1.58 \\
\hline 133 & 3.34 & 4.87 & 1.23 & 0.33 & 1.55 \\
\hline 134 & 3.33 & 4.48 & 0.79 & 0.22 & 1.61 \\
\hline 135 & 3.21 & 4.50 & 0.74 & 0.21 & 1.24 \\
\hline 136 & 3.17 & 4.34 & 0.63 & 0.18 & 1.12 \\
\hline
\end{tabular}


Table 4. Chemistry of major elements - Continued [In percent by weight]

\begin{tabular}{|c|c|c|c|c|c|}
\hline $\begin{array}{c}\text { Sample site } \\
\text { number }\end{array}$ & $\mathrm{Na}^{1}$ & $\mathrm{~K}^{2}$ & $\mathrm{Ca}^{2}$ & $\pi^{2}$ & $\mathrm{Fe}^{1}$ \\
\hline 137 & 3.12 & 4.14 & 0.50 & 0.17 & 1.08 \\
\hline 138 & 3.20 & 4.58 & 0.71 & 0.22 & 1.27 \\
\hline 139 & 3.13 & 4.10 & 0.96 & 0.16 & 0.98 \\
\hline 140 & 3.24 & 4.29 & 0.84 & 0.19 & 1.12 \\
\hline 141 & 3.17 & 4.17 & 1.11 & 0.16 & 1.11 \\
\hline 142 & 3.12 & 3.98 & 0.40 & 0.15 & 1.01 \\
\hline 143 & 3.00 & 4.12 & 1.27 & 0.16 & 1.00 \\
\hline 144 & 3.01 & 3.62 & 0.34 & 0.11 & 0.85 \\
\hline 145 & 3.03 & 3.99 & 0.62 & 0.15 & 1.01 \\
\hline 146 & 3.37 & 4.18 & 0.51 & 0.16 & 1.12 \\
\hline 147 & 3.30 & 4.21 & 0.42 & 0.16 & 1.17 \\
\hline 148 & 3.06 & 3.81 & 0.41 & 0.12 & 0.94 \\
\hline 149 & 3.15 & 4.21 & 0.72 & 0.17 & 1.11 \\
\hline 150 & 3.01 & 3.92 & 0.99 & 0.14 & 0.94 \\
\hline 151 & 3.10 & 4.08 & 0.71 & 0.16 & 1.05 \\
\hline 152 & 3.00 & 4.14 & 0.91 & 0.15 & 0.97 \\
\hline 153 & 3.25 & 4.07 & 0.40 & 0.14 & 1.03 \\
\hline 154 & 3.04 & 4.06 & 1.77 & 0.16 & 1.05 \\
\hline 155 & 3.04 & 4.00 & 1.08 & 0.15 & 1.04 \\
\hline 156 & 3.08 & 4.12 & 0.90 & 0.16 & 1.04 \\
\hline 157 & 3.46 & 3.95 & 0.76 & 0.15 & 1.22 \\
\hline 158 & 3.40 & 3.97 & 0.84 & 0.14 & 1.18 \\
\hline 159 & 3.65 & 3.99 & 0.92 & 0.15 & 1.29 \\
\hline
\end{tabular}


Table 5. Chemistry of common trace elements in the Tiva Canyon Tuff [In ppm by weight; <, less than]

\begin{tabular}{|c|c|c|c|c|c|c|c|c|c|c|c|c|c|}
\hline $\begin{array}{l}\text { Sample site } \\
\text { number }\end{array}$ & $S c^{1}$ & $\mathbf{R} \mathbf{b}^{1}$ & $\mathbf{R b ^ { 2 }}$ & $\mathrm{Sr}^{2}$ & $Y^{2}$ & $Z r^{2}$ & $\mathrm{Nb}^{2}$ & $\mathrm{Cs}^{1}$ & $\mathrm{Ba}^{1}$ & $\mathrm{Ba}^{2}$ & $H^{1}{ }^{1}$ & $T^{1}$ & $u^{1}$ \\
\hline 1 & 4.7 & 110 & 126 & 150 & 45 & 582 & 19 & 2 & 1,700 & 1,801 & 13 & 20 & 3.7 \\
\hline 2 & 5.0 & 100 & 107 & 215 & 38 & 640 & 17 & 2 & 2,100 & 2,484 & 13 & 17 & 2.5 \\
\hline 3 & 5.0 & 120 & 121 & 167 & 42 & 588 & 17 & 2 & 1,700 & 1,887 & 13 & 18 & 4.2 \\
\hline 4 & 4.8 & 120 & 127 & 150 & 41 & 547 & 17 & 2 & 1,800 & 1,798 & 12 & 18 & 4.9 \\
\hline 5 & 4.7 & 120 & 129 & 158 & 41 & 578 & 20 & 2 & 1,800 & 1,818 & 12 & 20 & 3.5 \\
\hline 6 & 5.0 & 100 & 118 & 181 & 45 & 616 & 17 & 2 & 2,000 & 2,162 & 13 & 18 & 3.7 \\
\hline 7 & 5.0 & 98 & 114 & 184 & 44 & 642 & 20 & 3 & 1,900 & 2,066 & 12 & 18 & 2.6 \\
\hline 8 & 4.6 & 100 & 110 & 178 & 40 & 619 & 18 & 2 & 1,700 & 2,021 & 12 & 17 & 3.1 \\
\hline 9 & 4.8 & 120 & 113 & 178 & 39 & 609 & 17 & 1 & 2,000 & 2,133 & 13 & 18 & 3.5 \\
\hline 10 & 4.7 & 100 & 120 & 161 & 40 & 560 & 18 & 2 & 1,600 & 1,776 & 12 & 19 & 3.9 \\
\hline 11 & 5.1 & 110 & 111 & 170 & 39 & 634 & 17 & 2 & 1,800 & 2,012 & 13 & 18 & 3.3 \\
\hline 12 & 4.6 & 95 & 112 & 179 & 39 & 580 & 18 & 2 & 1,700 & 2,057 & 12 & 18 & 3.2 \\
\hline 13 & 6.4 & 66 & 77 & 236 & 37 & 787 & 9 & $<1$ & 2,400 & 2,703 & 14 & 14 & $<0.5$ \\
\hline 14 & 4.6 & 110 & 124 & 158 & 39 & 566 & 19 & 2 & 1,600 & 1,822 & 13 & 19 & 4.1 \\
\hline 15 & 5.0 & 78 & 119 & 86 & 42 & 601 & 19 & 1 & 700 & 695 & 13 & 19 & 4.2 \\
\hline 16 & 4.6 & 95 & 122 & 158 & 37 & 554 & 17 & 1 & 1,700 & 1,805 & 12 & 20 & 4.1 \\
\hline 17 & 4.1 & 81 & 128 & 123 & 40 & 507 & 19 & $<1$ & 1,200 & 1,363 & 12 & 20 & 3.9 \\
\hline 18 & 4.3 & 100 & 121 & 147 & 39 & 517 & 19 & 2 & 1,600 & 1,756 & 12 & 19 & 3.4 \\
\hline 19 & 6.3 & 60 & 87 & 195 & 38 & 755 & 13 & $<1$ & 1,900 & 2,154 & 14 & 16 & 2.8 \\
\hline 20 & 5.0 & 110 & 115 & 169 & 37 & 594 & 20 & 2 & 1,800 & 1,995 & 13 & 18 & 3.1 \\
\hline 21 & 6.7 & 110 & 96 & 194 & 39 & 820 & 12 & $<1$ & 2,200 & 2,377 & 15 & 18 & 2.6 \\
\hline 22 & 5.1 & 95 & 117 & 160 & 38 & 575 & 19 & 2 & 1,800 & 1,959 & 13 & 18 & 3.7 \\
\hline 23 & 6.0 & 100 & 104 & 111 & 40 & 620 & 17 & 1 & 1,000 & 1,048 & 14 & 19 & 3.3 \\
\hline 24 & 7.4 & 75 & 94 & 188 & 40 & 779 & 12 & $<1$ & 2,100 & 2,202 & 15 & 16 & 2.4 \\
\hline 25 & 6.5 & 70 & 83 & 200 & 35 & 646 & 10 & 3 & 1,700 & 1,796 & 13 & 15 & 3.3 \\
\hline 26 & 5.3 & 92 & 103 & 113 & 38 & 613 & 16 & 2 & 1,100 & 1,146 & 13 & 19 & 2.8 \\
\hline 27 & 6.1 & 92 & 106 & 94 & 42 & 612 & 18 & 2 & 1,100 & 1,038 & 13 & 17 & 1.7 \\
\hline 28 & 5.4 & 79 & 113 & 102 & 40 & 602 & 20 & 2 & 1,100 & 1,081 & 13 & 19 & 3.9 \\
\hline 29 & 5.8 & 75 & 98 & 143 & 36 & 659 & 15 & $<1$ & 1,700 & 1,507 & 15 & 20 & 3.4 \\
\hline 30 & 4.6 & 95 & 119 & 75 & 43 & 528 & 18 & 2 & 690 & 696 & 13 & 21 & 3.9 \\
\hline 31 & 4.9 & 130 & 121 & 76 & 40 & 517 & 18 & 3 & 670 & 612 & 13 & 22 & 3.9 \\
\hline 32 & 5.0 & 83 & 129 & 75 & 43 & 588 & 21 & 2 & 700 & 733 & 14 & 22 & 3.7 \\
\hline
\end{tabular}


\& Table 5. Chemistry of common trace elements in the Tiva Canyon Tuff-Continued [In ppm by weight; <, less than]

\begin{tabular}{|c|c|c|c|c|c|c|c|c|c|c|c|c|c|}
\hline $\begin{array}{l}\text { Sample site } \\
\text { number }\end{array}$ & $\operatorname{Sc}^{1}$ & $\mathbf{A b} \mathbf{b}^{1}$ & $\mathbf{R} \mathbf{b}^{2}$ & $S r^{2}$ & $\mathbf{Y}^{2}$ & $2 r^{2}$ & $\mathrm{Nb}^{2}$ & $\mathrm{Cs}^{1}$ & $\mathbf{B a}^{1}$ & $\mathrm{Ba}^{2}$ & $H^{\prime}{ }^{1}$ & $T^{1}$ & $U^{t}$ \\
\hline 33 & 6.3 & 120 & 110 & 100 & 38 & 591 & 16 & 1 & 1,000 & 1,050 & 14 & 20 & 3.9 \\
\hline 34 & 5.5 & 130 & 122 & 70 & 44 & 532 & 21 & 2 & 640 & 672 & 14 & 22 & 3.7 \\
\hline 35 & 5.9 & 89 & 103 & 140 & 34 & 545 & 15 & 2 & 850 & 872 & 14 & 19 & 3.5 \\
\hline 36 & 5.2 & 150 & 143 & 61 & 44 & 503 & 22 & 3 & 540 & 509 & 13 & 22 & 4.5 \\
\hline 37 & 5.1 & 130 & 131 & 62 & 43 & 502 & 22 & 2 & 560 & 564 & 13 & 22 & 4.4 \\
\hline 38 & 5.7 & 130 & 108 & 91 & 41 & 595 & 17 & 2 & 960 & 885 & 13 & 21 & 3.7 \\
\hline 39 & 3.9 & 140 & 142 & 53 & 43 & 455 & 23 & 3 & 530 & 415 & 12 & 22 & 3.9 \\
\hline 40 & 6.3 & 110 & 132 & 101 & 45 & 644 & 18 & 2 & 1,000 & 1,035 & 15 & 20 & 3.7 \\
\hline 41 & 5.8 & 100 & 115 & 100 & 41 & 578 & 16 & 2 & 890 & 950 & 15 & 20 & 3.1 \\
\hline 42 & 6.7 & 110 & 110 & 103 & 44 & 637 & 17 & 2 & 1,100 & 1,049 & 15 & 20 & 4.0 \\
\hline 43 & 6.2 & 110 & 112 & 110 & 41 & 624 & 17 & 2 & 1,000 & 997 & 14 & 20 & 3.1 \\
\hline 44 & 5.0 & 130 & 119 & 83 & 38 & 502 & 19 & 2 & $\cdot 660$ & 591 & 13 & 21 & 3.7 \\
\hline 45 & 4.5 & 110 & 131 & 61 & 43 & 489 & 23 & $<1$ & 460 & 500 & 12 & 22 & 3.4 \\
\hline 46 & 6.0 & 120 & 118 & 104 & 48 & 620 & 18 & 3 & 820 & 934 & 14 & 19 & 3.3 \\
\hline 47 & 5.0 & 110 & 139 & 63 & 44 & 513 & 22 & 3 & 530 & 545 & 13 & 22 & 3.9 \\
\hline 48 & 8.4 & 68 & 97 & 166 & 42 & 790 & 14 & $<1$ & 2,200 & 2,013 & 17 & 19 & 2.5 \\
\hline 50 & 5.2 & 140 & 135 & 63 & 43 & 529 & 21 & 3 & 600 & 605 & 14 & 24 & 4.1 \\
\hline 51 & 1.6 & 170 & 181 & 23 & 36 & 199 & 30 & 2 & 180 & 76 & 9 & 26 & 6.2 \\
\hline 52 & 5.3 & 110 & 116 & 85 & 41 & 538 & 19 & 2 & 850 & 750 & 14 & 20 & 3.3 \\
\hline 53 & 5.0 & 120 & 133 & 89 & 43 & 535 & 22 & 3 & 780 & 684 & 13 & 21 & 3.1 \\
\hline 54 & 1.7 & 170 & 186 & 22 & 39 & 200 & 31 & 3 & 170 & 72 & 9 & 27 & 5.3 \\
\hline 55 & 5.2 & 120 & 110 & 97 & 36 & 529 & 17 & 2 & 770 & 717 & 14 & 20 & 3.5 \\
\hline 56 & 4.0 & 160 & 151 & 50 & 44 & 366 & 25 & 3 & 410 & 316 & 12 & 25 & 5.0 \\
\hline 57 & 4.8 & 120 & 137 & 72 & 44 & 462 & 21 & 2 & 590 & 545 & 12 & 22 & 5.0 \\
\hline 58 & 4.9 & 130 & 144 & 58 & 43 & 475 & 24 & 3 & 550 & 513 & 14 & 25 & 5.5 \\
\hline 59 & 5.8 & 120 & 128 & 73 & 44 & 547 & 22 & 2 & 770 & 703 & 14 & 22 & 4.2 \\
\hline 60 & 6.0 & 110 & 127 & 99 & 40 & 613 & 18 & 1 & 990 & 1,005 & 14 & 23 & 3.9 \\
\hline 61 & 4.9 & 120 & 127 & 70 & 44 & 511 & 21 & 2 & 710 & 625 & 13 & 23 & 5.0 \\
\hline 62 & 4.0 & 120 & 140 & 51 & 43 & 444 & 23 & 3 & 580 & 453 & 13 & 24 & 4.4 \\
\hline 63 & 2.8 & 150 & 163 & 44 & 44 & 341 & 28 & 3 & 240 & 243 & 11 & 25 & 4.4 \\
\hline 64 & 6.2 & 120 & 116 & 93 & 42 & 603 & 18 & 2 & 890 & 897 & 15 & 21 & 3.0 \\
\hline 65 & 5.5 & 110 & 117 & 82 & 41 & 551 & 19 & 2 & 720 & 675 & 13 & 21 & 3.5 \\
\hline 66 & 6.6 & 100 & 107 & 100 & 42 & 629 & 18 & 1 & 890 & 1,040 & 15 & 20 & 3.8 \\
\hline 67 & 5.5 & 120 & 117 & 95 & 44 & 595 & 20 & 2 & 890 & 897 & 14 & 21 & 3.9 \\
\hline
\end{tabular}


Table 5. Chemistry of common trace elements in the Tiva Canyon Tuff-Continued [In ppm by weight; < less than]

\begin{tabular}{|c|c|c|c|c|c|c|c|c|c|c|c|c|c|}
\hline $\begin{array}{c}\text { Sample site } \\
\text { number }\end{array}$ & $S c^{1}$ & $\mathbf{R} \mathbf{b}^{\mathbf{1}}$ & $R b^{2}$ & $S r^{2}$ & $Y^{2}$ & $Z r^{2}$ & $\mathrm{Nb}^{2}$ & $\mathrm{Cs}^{1}$ & $8 a^{1}$ & $\mathrm{Ba}^{2}$ & $H f^{1}$ & $T^{1}$ & $u^{1}$ \\
\hline 68 & 5.6 & 77 & 103 & 120 & 39 & 647 & 16 & 1 & 1,200 & 1,168 & 13 & 17 & 3.1 \\
\hline 69 & 4.7 & 91 & 126 & 64 & 43 & 519 & 20 & 2 & 620 & 589 & 13 & 22 & 4.1 \\
\hline 70 & 4.2 & 110 & 131 & 55 & 41 & 463 & 22 & 2 & 530 & 484 & 12 & 23 & 4.4 \\
\hline 71 & 3.4 & 140 & 147 & 52 & 40 & 388 & 22 & 3 & 390 & 339 & 11 & 23 & 4.5 \\
\hline 72 & 1.8 & 170 & 189 & 14 & 43 & 209 & 31 & 3 & 110 & 72 & 9 & 28 & 4.7 \\
\hline 73 & 4.7 & 150 & 142 & 57 & 43 & 452 & 23 & 3 & 420 & 466 & 13 & 24 & 4.9 \\
\hline 74 & 5.3 & 120 & 121 & 72 & 45 & 577 & 19 & 2 & 730 & 678 & 14 & 22 & 4.5 \\
\hline 75 & 2.8 & 160 & 160 & 51 & 38 & 315 & 26 & 3 & 300 & 212 & 11 & 25 & 4.9 \\
\hline 76 & 5.1 & 130 & 138 & 61 & 45 & 506 & 20 & 2 & 730 & 555 & 14 & 24 & 4.5 \\
\hline 77 & 4.4 & 120 & 139 & 62 & 44 & 480 & 22 & 2 & 490 & 500 & 12 & 23 & 4.6 \\
\hline 78 & 4.5 & 110 & 127 & 71 & 42 & 520 & 21 & 2 & 650 & 601 & 13 & 22 & 3.7 \\
\hline 79 & 4.5 & 96 & 138 & 59 & 40 & 506 & 21 & 2 & 560 & 547 & 13 & 23 & 4.1 \\
\hline 80 & 4.7 & 150 & 136 & 59 & 42 & 476 & 23 & 2 & 430 & 484 & 12 & 23 & 4.0 \\
\hline 81 & 4.3 & 110 & 131 & 65 & 42 & 477 & 22 & 2 & 520 & 540 & 13 & 23 & 4.5 \\
\hline 82 & 4.9 & 140 & 135 & 68 & 43 & 499 & 24 & 3 & 660 & 566 & 14 & 24 & 4.2 \\
\hline 83 & 3.1 & 150 & 153 & 53 & 38 & 332 & 26 & 3 & 290 & 245 & 11 & 25 & 6.0 \\
\hline 84 & 4.4 & 130 & 135 & 71 & 47 & 470 & 23 & 3 & 580 & 485 & 13 & 23 & 5.0 \\
\hline 85 & 4.4 & 76 & 122 & 84 & 40 & 491 & 20 & 2 & 660 & 634 & 12 & 20 & 3.7 \\
\hline 86 & 2.4 & 130 & 165 & 38 & 41 & 313 & 28 & 2 & 260 & 179 & 11 & 25 & 5.4 \\
\hline 87 & 3.5 & 140 & 146 & 59 & 39 & 380 & 25 & 3 & 390 & 329 & 11 & 22 & 3.9 \\
\hline 88 & 2.9 & 150 & 149 & 64 & 41 & 325 & 25 & 3 & 270 & 229 & 11 & 25 & 4.8 \\
\hline 89 & 3.6 & 130 & 151 & 47 & 43 & 391 & 23 & 3 & 350 & 336 & 12 & 24 & 4.9 \\
\hline 90 & 4.8 & 110 & 140 & 61 & 47 & 476 & 22 & 3 & 700 & 499 & 14 & 23 & 3.8 \\
\hline 91 & 3.7 & 120 & 141 & 58 & 40 & 420 & 22 & 2 & 460 & 416 & 12 & 23 & 5.2 \\
\hline 92 & 5.2 & 120 & 134 & 61 & 42 & 475 & 23 & 3 & 580 & 510 & 13 & 23 & 4.1 \\
\hline 93 & 5.9 & 100 & 102 & 103 & 40 & 550 & 15 & 2 & 910 & 846 & 14 & 20 & 2.9 \\
\hline 94 & 6.5 & 79 & 101 & 112 & 42 & 660 & 17 & 2 & 1,200 & 1,140 & 15 & 20 & 4.5 \\
\hline 95 & 6.0 & 96 & 104 & 104 & 43 & 620 & 18 & 2 & 960 & 945 & 15 & 19 & 4.1 \\
\hline 96 & 6.4 & 90 & 99 & 103 & 41 & 625 & 18 & 2 & 1,100 & 1,022 & 15 & 20 & 3.2 \\
\hline 97 & 6.5 & 110 & 114 & 103 & 42 & 631 & 20 & 2 & 990 & 952 & 15 & 20 & 2.7 \\
\hline 98 & 1.9 & 160 & 172 & 46 & 41 & 246 & 30 & 3 & 240 & 226 & 10 & 26 & 5.0 \\
\hline 99 & 4.1 & 110 & 144 & 57 & 44 & 442 & 26 & 3 & 370 & 419 & 13 & 23 & 3.9 \\
\hline 100 & 5.0 & 130 & 133 & 67 & 43 & 536 & 23 & 3 & 560 & 587 & 14 & 22 & 2.8 \\
\hline 101 & 4.9 & 130 & 134 & 61 & 47 & 496 & 22 & 2 & 520 & 503 & 12 & 22 & 3.8 \\
\hline
\end{tabular}


w Table 5. Chemistry of common trace elements in the Tiva Canyon Tuff-Continued [In ppm by weight: $<$, less than]

\begin{tabular}{|c|c|c|c|c|c|c|c|c|c|c|c|c|c|}
\hline $\begin{array}{c}\text { Sample slte } \\
\text { number }\end{array}$ & $S c^{1}$ & $\mathbf{R} \mathbf{b}^{1}$ & $\mathbf{R b}^{2}$ & $S r^{2}$ & $y^{2}$ & $\mathrm{zr}^{2}$ & $\mathrm{Nb}^{2}$ & $\mathrm{Cs}^{1}$ & $\mathrm{Ba}^{1}$ & $\mathrm{Ba}^{2}$ & $H f^{1}$ & $T^{1}$ & $u^{1}$ \\
\hline 102 & 4.1 & 140 & 145 & 60 & 44 & 445 & 25 & 2 & 430 & 386 & 12 & 23 & 4.6 \\
\hline 103 & 2.1 & 160 & 176 & 36 & 43 & 260 & 31 & 2 & 220 & 153 & 10 & 26 & 4.9 \\
\hline 104 & 1.9 & 150 & 177 & 36 & 39 & 239 & 32 & 2 & 150 & 131 & 9 & 24 & 4.5 \\
\hline 105 & 2.5 & 150 & 176 & 32 & 45 & 295 & 29 & 3 & 180 & 164 & 10 & 26 & 5.3 \\
\hline 106 & 2.3 & 140 & 166 & 43 & 41 & 297 & 30 & 2 & 190 & 173 & 10 & 24 & 4.3 \\
\hline 107 & 3.0 & 130 & 144 & 70 & 39 & 327 & 25 & 3 & 220 & 206 & 10 & 23 & 6.1 \\
\hline 108 & 2.3 & 170 & 172 & 45 & 43 & 285 & 27 & 3 & 250 & 193 & 11 & 25 & 5.1 \\
\hline 110 & 2.3 & 140 & 168 & 41 & 40 & 280 & 29 & 3 & 300 & 163 & 10 & 24 & 4.9 \\
\hline 111 & 4.8 & 130 & 130 & 74 & 43 & 493 & 20 & 2 & 630 & 614 & 12 & 23 & 2.8 \\
\hline 112 & 4.8 & 120 & 131 & 74 & 40 & 500 & 22 & 2 & 560 & 590 & 12 & 22 & 4.0 \\
\hline 113 & 4.5 & 120 & 137 & 63 & 40 & 471 & 22 & 2 & 470 & 480 & 12 & 22 & 4.8 \\
\hline 114 & 2.9 & 160 & 162 & 53 & 40 & 310 & 27 & 3 & 240 & 225 & 11 & 23 & 5.0 \\
\hline 115 & 3.3 & 150 & 160 & 60 & 41 & 340 & 25 & 3 & 300 & 223 & 11 & 25 & 5.5 \\
\hline 116 & 5.1 & 110 & 138 & 83 & 41 & 541 & 21 & 2 & 700 & 691 & 13 & 23 & 4.0 \\
\hline 117 & 2.7 & 170 & 165 & 35 & 40 & 328 & 29 & 2 & 520 & 223 & 10 & 26 & 5.2 \\
\hline 118 & 4.9 & 130 & 135 & 77 & 41 & 465 & 22 & 2 & 560 & 535 & 13 & 22 & 4.2 \\
\hline 119 & 2.6 & 160 & 169 & 30 & 39 & 303 & 29 & 3 & 220 & 174 & 10 & 25 & 4.9 \\
\hline 120 & 4.4 & 140 & 139 & 62 & 42 & 475 & 23 & 3 & 570 & 502 & 13 & 23 & 4.6 \\
\hline 121 & 5.3 & 130 & 136 & 65 & 44 & 530 & 20 & 2 & 650 & 582 & 14 & 22 & 3.6 \\
\hline 122 & 3.4 & 170 & 170 & 42 & 42 & 360 & 26 & 2 & 430 & 265 & 12 & 27 & 5.6 \\
\hline 123 & 5.9 & 130 & 124 & 73 & 41 & 532 & 19 & 2 & 750 & 676 & 14 & 22 & 4.6 \\
\hline 124 & 2.1 & 160 & 171 & 52 & 42 & 248 & 30 & 3 & 230 & 210 & 10 & 26 & 4.3 \\
\hline 125 & 2.1 & 150 & 174 & 38 & 39 & 292 & 31 & 3 & 150 & 163 & 9 & 24 & 5.2 \\
\hline 126 & 1.9 & 160 & 169 & 49 & 41 & 268 & 30 & 3 & 220 & 177 & 9 & 23 & 4.0 \\
\hline 127 & 2.5 & 140 & 155 & 77 & 40 & 343 & 26 & 3 & 260 & 242 & 9 & 22 & 4.5 \\
\hline 128 & 3.3 & 140 & 152 & 47 & 45 & 374 & 25 & 3 & 450 & 316 & 11 & 23 & 4.2 \\
\hline 129 & 3.7 & 130 & 148 & 50 & 34 & 427 & 24 & 3 & 450 & 386 & 11 & 23 & 4.0 \\
\hline 130 & 4.0 & 110 & 137 & 59 & 47 & 490 & 23 & 2 & 430 & 465 & 12 & 21 & 3.4 \\
\hline 131 & 3.8 & 120 & 139 & 57 & 43 & 453 & 25 & 3 & 470 & 462 & 11 & 20 & 4.3 \\
\hline 132 & 7.0 & 80 & 82 & 230 & 38 & 821 & 12 & 2 & 2,400 & 2,836 & 14 & 14 & 2.6 \\
\hline 133 & 6.8 & 88 & 86 & 227 & 37 & 831 & 10 & $<1$ & 2,300 & 2,738 & 15 & 15 & 1.7 \\
\hline 134 & 6.3 & 110 & 124 & 67 & 39 & 538 & 20 & 3 & 730 & 589 & 16 & 24 & 3.8 \\
\hline 135 & 4.8 & 94 & 112 & 76 & 38 & 533 & 18 & 2 & 640 & 681 & 12 & 18 & 2.9 \\
\hline 136 & 4.0 & 100 & 138 & 65 & 42 & 469 & 23 & 2 & 490 & 494 & 12 & 21 & 3.4 \\
\hline
\end{tabular}


Table 5. Chemistry of common trace elements in the Tiva Canyon Tuff-Continued

[In ppm by weights $<$ less than]

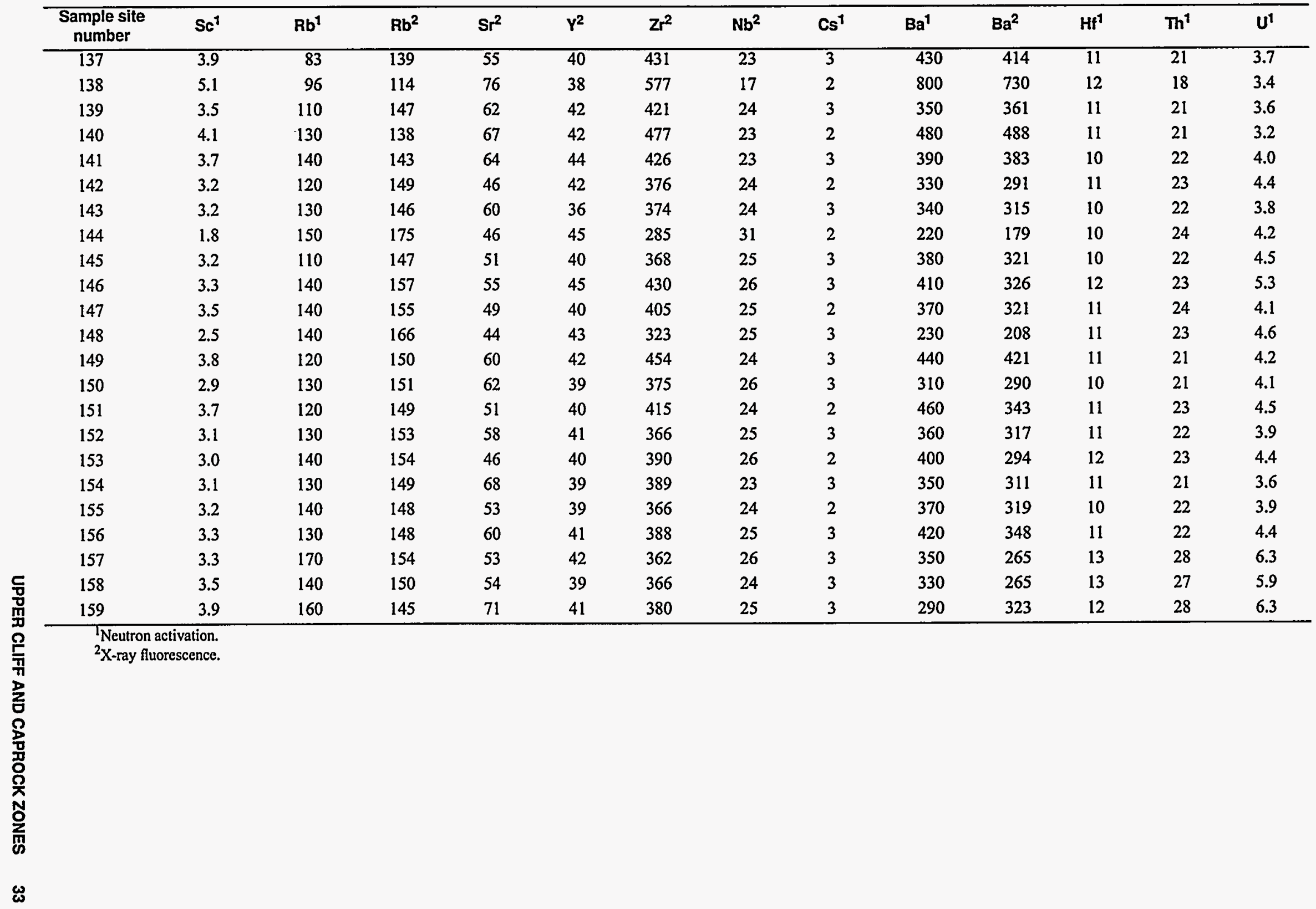


Table 6. Chemistry of rare earth elements in the Tiva Canyon Tuff [In ppm by weight; <, less than]

\begin{tabular}{|c|c|c|c|c|c|c|c|c|c|c|}
\hline $\begin{array}{l}\text { Samplesite } \\
\text { number }\end{array}$ & $\mathrm{La}^{1}$ & $\mathrm{La}^{2}$ & $\mathrm{Ce}^{1}$ & $\mathrm{Ce}^{2}$ & $N d^{1}$ & $\mathrm{Sm}^{1}$ & $\mathrm{Eu}^{1}$ & $\mathrm{~Tb}^{1}$ & $\mathbf{Y b}^{1}$ & $\operatorname{Lu}^{1}$ \\
\hline 1 & 150 & 152 & 250 & 251 & 82 & 11 & 2.8 & 1.1 & 3.4 & 0.50 \\
\hline 2 & 160 & 139 & 270 & 282 & 88 & 11 & 3.2 & 0.9 & 3.0 & 0.38 \\
\hline 3 & 140 & 148 & 250 & 258 & 75 & 11 & 2.9 & 1.4 & 3.4 & 0.46 \\
\hline 4 & 150 & 151 & 260 & 261 & 81 & 11 & 2.9 & 1.3 & 3.5 & 0.48 \\
\hline 5 & 150 & 146 & 250 & 249 & 91 & 11 & 3.0 & 1.0 & 3.5 & 0.46 \\
\hline 6 & 150 & 171 & 260 & 279 & 91 & 11 & 3.1 & 1.4 & 3.7 & 0.51 \\
\hline 7 & 160 & 165 & 270 & 279 & 87 & 11 & 3.1 & 1.3 & 3.5 & 0.51 \\
\hline 8 & 160 & 169 & 260 & 277 & 83 & 11 & 3.0 & 1.0 & 3.2 & 0.44 \\
\hline 9 & 160 & 153 & 270 & 275 & 90 & 11 & 3.2 & 1.0 & 3.3 & 0.47 \\
\hline 10 & 140 & 144 & 250 & 238 & 82 & 11 & 2.8 & 1.0 & 3.1 & 0.46 \\
\hline 11 & 160 & 180 & 280 & 292 & 93 & 11 & 3.0 & 1.0 & 3.4 & 0.42 \\
\hline 12 & 140 & 151 & 250 & 263 & 80 & 10 & 2.8 & 1.2 & 3.0 & 0.43 \\
\hline 13 & 210 & 229 & 360 & 383 & 120 & 13 & 4.2 & 1.4 & 2.7 & 0.42 \\
\hline 14 & 140 & 156 & 260 & 252 & 85 & 10 & 2.9 & 1.1 & 3.2 & 0.46 \\
\hline 15 & 170 & 192 & 300 & 302 & 98 & 13 & 2.4 & 1.4 & 3.5 & 0.51 \\
\hline 16 & 150 & 149 & 250 & 254 & 80 & 10 & 2.8 & 1.4 & 3.4 & 0.46 \\
\hline 17 & 120 & 134 & 210 & 224 & 75 & 9 & 2.2 & 1.4 & 3.2 & 0.43 \\
\hline 18 & 140 & 138 & 240 & 240 & 78 & 10 & 2.6 & 1.0 & $\cdot 3.4$ & 0.43 \\
\hline 19 & 210 & 228 & 360 & 372 & 120 & 13 & 3.8 & 0.9 & 3.1 & 0.47 \\
\hline 20 & 160 & 156 & 270 & 267 & 91 & 13 & 3.1 & 1.2 & 2.7 & 0.46 \\
\hline 21 & 230 & 251 & 410 & 406 & 130 & 15 & 4.3 & 1.2 & 3.2 & 0.44 \\
\hline 22 & 160 & 153 & 270 & 272 & 91 & 11 & 3.1 & 1.2 & 3.3 & 0.46 \\
\hline 23 & 190 & 207 & 340 & 314 & 110 & 16 & 3.0 & 1.2 & 3.2 & 0.56 \\
\hline 24 & 240 & 231 & 420 & 386 & 140 & 18 & 4.6 & 1.2 & 3.1 & 0.58 \\
\hline 25 & 210 & 209 & 360 & 334 & 130 & 16 & 3.8 & 1.2 & 3.0 & 0.47 \\
\hline 26 & 180 & 212 & 310 & 329 & 110 & 13 & 3.0 & 1.5 & 3.3 & 0.48 \\
\hline 27 & 200 & 206 & 330 & 331 & 120 & 17 & 3.3 & 1.1 & 3.0 & 0.48 \\
\hline 28 & 180 & 220 & 320 & 330 & 95 & 13 & 2.8 & 1.4 & 3.7 & 0.48 \\
\hline 29 & 200 & 217 & 360 & 340 & 120 & 14 & 3.4 & 1.2 & 3.4 & 0.49 \\
\hline 30 & 150 & 178 & 280 & 277 & 94 & 12 & 2.2 & 1.5 & 3.7 & 0.48 \\
\hline 31 & 160 & 187 & 290 & 284 & 100 & 13 & 2.2 & 1.5 & 3.9 & 0.50 \\
\hline 32 & 170 & 195 & 310 & 306 & 110 & 13 & 2.5 & 1.5 & 3.8 & 0.52 \\
\hline 33 & 200 & 198 & 360 & 317 & 130 & 17 & 3.3 & 1.1 & 3.3 & 0.58 \\
\hline 34 & 180 & 189 & 330 & 285 & 120 & 17 & 2.7 & 1.4 & 3.8 & 0.57 \\
\hline 35 & 200 & 199 & 360 & 301 & 120 & 16 & 3.0 & 1.1 & 3.4 & 0.60 \\
\hline 36 & 150 & 158 & 290 & 264 & 100 & 16 & $2.3^{\circ}$ & 1.2 & 4.1 & 0.58 \\
\hline 37 & 160 & 160 & 290 & 245 & 100 & 15 & 2.3 & 1.5 & 3.8 & 0.61 \\
\hline 38 & 190 & 202 & 350 & 317 & 110 & 17 & 3.0 & 1.5 & 3.9 & 0.56 \\
\hline 39 & 120 & 131 & 230 & 212 & 85 & 13 & 1.8 & 1.1 & 3.9 & 0.58 \\
\hline 40 & 210 & 234 & 380 & 346 & 130 & 18 & 3.5 & 1.2 & 3.8 & 0.61 \\
\hline 41 & 180. & 198 & 330 & 290 & 120 & 16 & 2.9 & 1.3 & 3.5 & 0.56 \\
\hline 42 & 220 & 215 & 400 & 341 & 120 & 18 & 3.5 & 1.6 & 3.9 & 0.59 \\
\hline 43 & 200 & 205 & 360 & 314 & 120 & 18 & 2.9 & 1.0 & 3.7 & 0.61 \\
\hline 44 & 160 & 173 & 290 & 271 & 100 & 15 & 2.2 & 1.1 & 3.6 & 0.61 \\
\hline 45 & 140 & 176 & 260 & 270 & 96 & 15 & 2.2 & 1.4 & 3.6 & 0.59 \\
\hline
\end{tabular}


Table 6. Chemistry of rare earth elements in the Tiva Canyon Tuff-Continued

[In ppm by weight; <, less than]

\begin{tabular}{|c|c|c|c|c|c|c|c|c|c|c|}
\hline $\begin{array}{c}\text { Samplesite } \\
\text { number }\end{array}$ & $\mathrm{La}^{1}$ & $\mathrm{La}^{2}$ & $\mathrm{Ce}^{1}$ & $\mathrm{Ce}^{2}$ & $N d^{1}$ & $S m^{1}$ & $\mathrm{Eu}^{1}$ & $\mathrm{~Tb}^{1}$ & $\mathrm{Yb}^{1}$ & $L u^{1}$ \\
\hline 46 & 180 & 208 & 330 & 318 & 110 & 17 & 3.0 & 1.5 & 3.4 & 0.57 \\
\hline 47 & 150 & 173 & 280 & 259 & 96 & 15 & 2.2 & 1.3 & 3.6 & 0.57 \\
\hline 48 & 260 & 223 & 460 & 368 & 160 & 20 & 4.7 & 1.2 & 3.6 & 0.59 \\
\hline 50 & 160 & 172 & 300 & 279 & 110 & 16 & 2.5 & 1.5 & 3.9 & 0.58 \\
\hline 51 & 33 & 53 & 74 & 83 & 30 & 7 & 0.3 & 1.3 & 3.8 & 0.51 \\
\hline 52 & 170 & 177 & 310 & 281 & 100 & 16 & 2.6 & 1.4 & 3.7 & 0.62 \\
\hline 53 & 160 & 177 & 290 & 269 & 99 & 15 & .2 .4 & 1.2 & 3.6 & 0.59 \\
\hline 54 & 35 & 57 & 80 & 70 & 30 & 8 & 0.5 & 1.0 & 4.0 & 0.57 \\
\hline 55 & 180 & 178 & 320 & 276 & 120 & 16 & 2.7 & 1.2 & 3.3 & 0.59 \\
\hline 56 & 100 & 106 & 210 & 172 & 76 & 13 & 1.6 & 1.2 & 4.3 & 0.68 \\
\hline 57 & 150 & 152 & 280 & 238 & 100 & 15 & 2.2 & 1.5 & 3.7 & 0.64 \\
\hline 58 & 150 & 158 & 290 & 253 & 98 & 15 & 2.4 & 1.7 & 4.5 & 0.65 \\
\hline 59 & 190 & 198 & 350 & 296 & 130 & 17 & 2.9 & 1.2 & 4.3 & 0.65 \\
\hline 60 & 210 & 192 & 370 & 314 & 130 & 18 & 3.3 & 1.7 & 3.9 & 0.64 \\
\hline 61 & 160 & 184 & 300 & 271 & 97 & 13 & 2.2 & 1.7 & 4.1 & 0.56 \\
\hline 62 & 130 & 151 & 250 & 238 & 77 & 12 & 1.9 & 1.5 & 4.1 & 0.55 \\
\hline 63 & 71 & 88 & 140 & 144 & 53 & 9 & 1.0 & 1.4 & -4.1 & 0.53 \\
\hline 64 & 200 & 195 & 350 & 307 & 130 & 18 & 3.1 & 0.8 & 4.0 & 0.57 \\
\hline 65 & 190 & 217 & 340 & 326 & 110 & 14 & 2.6 & 1.5 & 3.8 & 0.52 \\
\hline 66 & 210 & 234 & 400 & 342 & 140 & 19 & 3.6 & 1.4 & 3.8 & 0.59 \\
\hline 67 & 180 & 187 & 320 & 306 & 110 & 14 & 2.7 & 1.7 & 4.0 & 0.60 \\
\hline 68 & 180 & 210 & 310 & 329 & 94 & 13 & 2.9 & 1.2 & 3.6 & 0.47 \\
\hline 69 & 150 & 178 & 280 & 257 & 97 & 13 & 2.2 & 1.3 & 4.2 & 0.57 \\
\hline 70 & 130 & 154 & 240 & 241 & 86 & 12 & 1.9 & 1.4 & 4.1 & 0.55 \\
\hline 71 & 100 & 133 & 190 & 198 & 68 & 10 & 1.3 & 1.1 & 3.9 & 0.54 \\
\hline 72 & 35 & 46 & 81 & 78 & 31 & 8 & 0.4 & 0.9 & 4.3 & 0.62 \\
\hline 73 & 140 & 155 & 250 & 225 & 94 & 15 & 2.0 & 1.3 & 4.4 & 0.63 \\
\hline 74 & 170 & 185 & 310 & 275 & 110 & 14 & 2.5 & 1.4 & 4.2 & 0.58 \\
\hline 75 & 74 & 104 & 150 & 152 & 51 & 9 & 0.9 & 1.2 & 4.2 & 0.54 \\
\hline 76 & 160 & 171 & 300 & 266 & 110 & 16 & 2.4 & 1.6 & 4.1 & 0.62 \\
\hline 77 & 130 & 150 & 250 & 230 & 85 & 12 & 1.9 & 1.5 & 4.0 & 0.56 \\
\hline 78 & 150 & 171 & 270 & 272 & 90 & 12 & 2.2 & 1.0 & 4.0 & 0.55 \\
\hline 79 & 150 & 169 & 280 & 266 & 94 & 12 & 2.1 & 1.3 & 4.1 & 0.54 \\
\hline 80 & 140 & 164 & 260 & 240 & 93 & 14 & 2.0 & 1.6 & 3.7 & 0.58 \\
\hline 81 & 140 & 160 & 260 & 240 & 87 & 12 & 2.0 & 1.4 & 4.1 & 0.56 \\
\hline 82 & 150 & 154 & 280 & 251 & 97 & 13 & 2.1 & 1.7 & 4.4 & 0.56 \\
\hline 83 & 82 & 101 & 170 & 163 & 61 & 10 & 1.0 & 1.4 & 4.1 & 0.55 \\
\hline 84 & 140 & 153 & 270 & 233 & 100 & 16 & 2.2 & 1.5 & 4.3 & 0.69 \\
\hline 85 & 140 & 164 & 260 & 246 & 89 & 14 & 2.1 & 1.1 & 3.3 & 0.54 \\
\hline 86 & 63 & 87 & 130 & 134 & 46 & 8 & 0.7 & 1.4 & 4.1 & 0.53 \\
\hline 87 & 100 & 113 & 200 & 178 & 70 & 12 & 1.5 & 1.2 & 3.9 & 0.55 \\
\hline 88 & 78 & 96 & 150 & 151 & 53 & 9 & 1.0 & 1.2 & 4.0 & 0.52 \\
\hline 89 & 100 & 131 & 190 & 186 & 72 & 10 & 1.4 & 1.3 & 4.2 & 0.56 \\
\hline 90 & 150 & 158 & 270 & 246 & 97 & 16 & 2.2 & 1.4 & 4.2 & 0.67 \\
\hline 91 & 120 & 134 & 220 & 204 & 74 & 11 & 1.7 & 1.2 & 4.1 & 0.57 \\
\hline
\end{tabular}


Table 6. Chemistry of rare earth elements in the Tiva Canyon Tuff-Continued [In ppm by weight; <, less than]

\begin{tabular}{|c|c|c|c|c|c|c|c|c|c|c|}
\hline $\begin{array}{l}\text { Samplesite } \\
\text { number }\end{array}$ & $\mathrm{La}^{1}$ & $\mathrm{La}^{2}$ & $\mathrm{Ce}^{1}$ & $C e^{2}$ & $\mathrm{Nd}^{1}$ & $\mathrm{Sm}^{1}$ & $\mathrm{Eu}^{1}$ & $\mathrm{~Tb}^{1}$ & $\mathrm{Yb}^{1}$ & $L^{1}$ \\
\hline 92 & 160 & 173 & 300 & 263 & 110 & 16 & 2.3 & 1.2 & 4.0 & 0.62 \\
\hline 93 & 180 & 189 & 330 & 279 & 120 & 17 & 3.0 & 1.1 & 3.8 & 0.61 \\
\hline 94 & 200 & 216 & 370 & 328 & 130 & 18 & 3.3 & 1.5 & 3.4 & 0.56 \\
\hline 95 & 200 & 193 & 360 & 320 & 120 & 18 & 3.2 & 1.6 & 3.5 & 0.60 \\
\hline 96 & 210 & 225 & 370 & 351 & 130 & 18 & 3.4 & 1.7 & 3.3 & 0.55 \\
\hline 97 & 200 & 207 & 370 & 325 & 130 & 18 & 3.1 & $<0.5$ & 3.6 & 0.62 \\
\hline 98 & 41 & 45 & 91 & 84 & 42 & 9 & 0.5 & 1.1 & 4.2 & 0.60 \\
\hline 99 & 130 & 146 & 240 & 217 & 80 & 14 & 1.6 & 1.3 & 4.0 & 0.61 \\
\hline 100 & 160 & 190 & 300 & 283 & 110 & 16 & 2.3 & $<0.5$ & 3.8 & 0.61 \\
\hline 101 & 150 & 158 & 270 & 230 & 100 & 15 & 2.1 & 1.5 & 4.0 & 0.63 \\
\hline 102 & 120 & 134 & 230 & 214 & 87 & 13 & 1.6 & 1.5 & 3.9 & 0.59 \\
\hline 103 & 46 & 59 & 100 & 105 & 39 & 9 & 0.6 & 1.4 & 3.9 & 0.57 \\
\hline 104 & 37 & 55 & 81 & 67 & 31 & 8 & 0.5 & $<0.5$ & 3.6 & 0.49 \\
\hline 105 & 54 & 69 & 120 & 101 & 51 & 10 & 0.7 & 1.5 & 4.4 & 0.65 \\
\hline 106 & 56 & 69 & 120 & 114 & 45 & 10 & 0.8 & 1.3 & 4.0 & 0.61 \\
\hline 107 & 75 & 85 & 150 & 135 & 54 & 11 & 1.1 & 1.2 & 3.9 & 0.56 \\
\hline 108 & 56 & 69 & 120 & 112 & 49 & 10 & 0.8 & 1.1 & 4.0 & 0.61 \\
\hline 110 & 54 & 63 & 120 & 105 & 38 & 10 & 0.6 & 1.4 & 4.0 & 0.57 \\
\hline 111 & 150 & 168 & 290 & 256 & 100 & 16 & 2.3 & 1.5 & 3.9 & 0.64 \\
\hline 112 & 150 & 162 & 280 & 276 & 90 & 15 & 2.4 & 1.3 & 3.8 & 0.54 \\
\hline 113 & 140 & 157 & 270 & 241 & 97 & 14 & 2.0 & $<0.5$ & 4.2 & 0.66 \\
\hline 114 & 77 & 91 & 160 & 140 & 63 & 11 & 1.1 & $<0.5$ & 4.1 & 0.56 \\
\hline 115 & 88 & 89 & 180 & 150 & 66 & 12 & 1.1 & 1.5 & 4.3 & 0.64 \\
\hline 116 & 160 & 170 & 310 & 262 & 110 & 16 & 2.5 & $<0.5$ & 4.0 & 0.63 \\
\hline 117 & 75 & 99 & 150 & 152 & 57 & 11 & 1.0 & 1.3 & 4.1 & 0.62 \\
\hline 118 & 150 & 152 & 280 & 253 & 98 & 15 & 2.2 & 1.5 & 4.0 & 0.59 \\
\hline 119 & 68 & 85 & 140 & 143 & 48 & 10 & 0.8 & 1.0 & 4.3 & 0.58 \\
\hline 120 & 140 & 157 & 270 & 245 & 100 & 15 & 2.0 & 1.2 & 4.2 & 0.61 \\
\hline 121 & 170 & 177 & 320 & 271 & 120 & 16 & 2.6 & 1.5 & 4.1 & 0.63 \\
\hline 122 & 91 & 106 & 190 & 177 & 67 & 12 & 1.3 & $<0.5$ & 4.5 & 0.68 \\
\hline 123 & 180 & 185 & 340 & 289 & 110 & 17 & 2.6 & $<0.5$ & 4.1 & 0.61 \\
\hline 124 & 42 & 53 & 100 & 92 & 39 & 9 & 0.5 & 1.0 & 4.2 & 0.54 \\
\hline 125 & 52 & 70 & 110 & 109 & 40 & 8 & 0.7 & 1.1 & 3.4 & 0.49 \\
\hline 126 & 42 & 63 & 88 & 108 & 34 & 7 & 0.5 & 1.1 & 3.6 & 0.50 \\
\hline 127 & 69 & 93 & 130 & 147 & 47 & 9 & 0.9 & 1.0 & 3.6 & 0.46 \\
\hline 128 & 93 & 113 & 170 & 177 & 64 & 10 & 1.3 & 1.3 & 3.6 & 0.51 \\
\hline 129 & 91 & 100 & 220 & 234 & 54 & 8 & 1.4 & 1.0 & 3.0 & 0.44 \\
\hline 130 & 130 & 170 & 240 & 251 & 82 & 12 & 1.8 & 1.4 & 3.5 & 0.52 \\
\hline 131 & 120 & 150 & 220 & 235 & 76 & 11 & 1.6 & 1.1 & 3.6 & 0.46 \\
\hline 132 & 240 & 230 & 400 & 389 & 130 & 15 & 4.5 & 1.3 & 2.7 & 0.42 \\
\hline 133 & 240 & 240 & 400 & 388 & 120 & 15 & 4.5 & 1.2 & 2.8 & 0.37 \\
\hline 134 & 200 & 196 & 340 & 295 & 120 & 15 & 2.7 & 1.2 & 4.2 & 0.60 \\
\hline 135 & 160 & 199 & 290 & 297 & 88 & 13 & 2.3 & 1.2 & 3.2 & 0.43 \\
\hline 136 & 130 & 158 & 230 & 232 & 74 & 11 & 1.7 & 1.2 & 3.5 & 0.48 \\
\hline 137 & 120 & 144 & 210 & 226 & 71 & 11 & 1.5 & 1.4 & 3.6 & 0.47 \\
\hline
\end{tabular}


Table 6. Chemistry of rare earth elements in the Tiva Canyon Tuff-Continued

[In ppm by weight; <, less than]

\begin{tabular}{lrrrrrrrrrr}
\hline $\begin{array}{c}\text { Sampleslte } \\
\text { number }\end{array}$ & $\mathrm{La}^{1}$ & $\mathrm{La}^{2}$ & $\mathrm{Ce}^{1}$ & $\mathrm{Ce}^{2}$ & $\mathrm{Nd}^{1}$ & $\mathrm{Sm}^{1}$ & $\mathrm{Eu}^{1}$ & $\mathrm{~Tb}^{1}$ & $\mathbf{Y b}^{1}$ & $\mathrm{Lu}^{1}$ \\
\hline 138 & 170 & 200 & 280 & 313 & 93 & 12 & 2.2 & 1.3 & 3.1 & 0.47 \\
139 & 110 & 138 & 190 & 220 & 60 & 10 & 1.4 & 1.3 & 3.5 & 0.48 \\
140 & 130 & 162 & 230 & 238 & 74 & 12 & 1.9 & 1.2 & 3.6 & 0.48 \\
141 & 110 & 140 & 200 & 220 & 66 & 11 & 1.5 & 1.0 & 3.9 & 0.49 \\
142 & 88 & 113 & 170 & 183 & 52 & 10 & 1.1 & 1.4 & 3.7 & 0.49 \\
143 & 90 & 121 & 170 & 193 & 53 & 9 & 1.2 & 1.4 & 3.5 & 0.44 \\
144 & 41 & 54 & 90 & 95 & 30 & 8 & 0.5 & 1.4 & 3.6 & 0.47 \\
145 & 89 & 111 & 170 & 165 & 60 & 9 & 1.0 & 1.0 & 3.3 & 0.44 \\
146 & 98 & 135 & 180 & 191 & 66 & 11 & 1.3 & 1.3 & 4.0 & 0.53 \\
147 & 100 & 112 & 180 & 178 & 65 & 10 & 1.4 & 1.3 & 3.9 & 0.51 \\
148 & 64 & 90 & 130 & 140 & 47 & 10 & 0.8 & 1.3 & 3.7 & 0.54 \\
149 & 120 & 159 & 210 & 247 & 73 & 11 & 1.5 & 1.1 & 3.8 & 0.49 \\
150 & 85 & 107 & 150 & 171 & 54 & 9 & 1.0 & 1.3 & 3.7 & 0.47 \\
151 & 100 & 133 & 190 & 192 & 62 & 10 & 1.3 & 1.1 & 3.7 & 0.50 \\
152 & 91 & 125 & 160 & 197 & 50 & 9 & 1.1 & 1.2 & 3.6 & 0.46 \\
153 & 93 & 110 & 170 & 175 & 61 & 10 & 1.2 & 1.3 & 3.8 & 0.50 \\
154 & 92 & 110 & 170 & 182 & 61 & 10 & 1.1 & 1.2 & 3.7 & 0.49 \\
155 & 92 & 107 & 170 & 175 & 57 & 10 & 1.1 & 1.3 & 3.5 & 0.49 \\
156 & 97 & 115 & 180 & 183 & 58 & 10 & 1.3 & 1.3 & 4.0 & 0.50 \\
157 & 93 & 108 & 190 & 167 & 67 & 11 & 1.3 & 1.3 & 4.3 & 0.59 \\
158 & 93 & 106 & 190 & 170 & 67 & 11 & 1.5 & 1.5 & 4.2 & 0.54 \\
159 & 110 & 120 & 230 & 177 & 72 & 12 & 1.6 & 1.7 & 4.7 & 0.62 \\
\hline 1
\end{tabular}

${ }^{i}$ Neutron activation.

${ }^{2} \mathrm{X}$-ray fluorescence. 

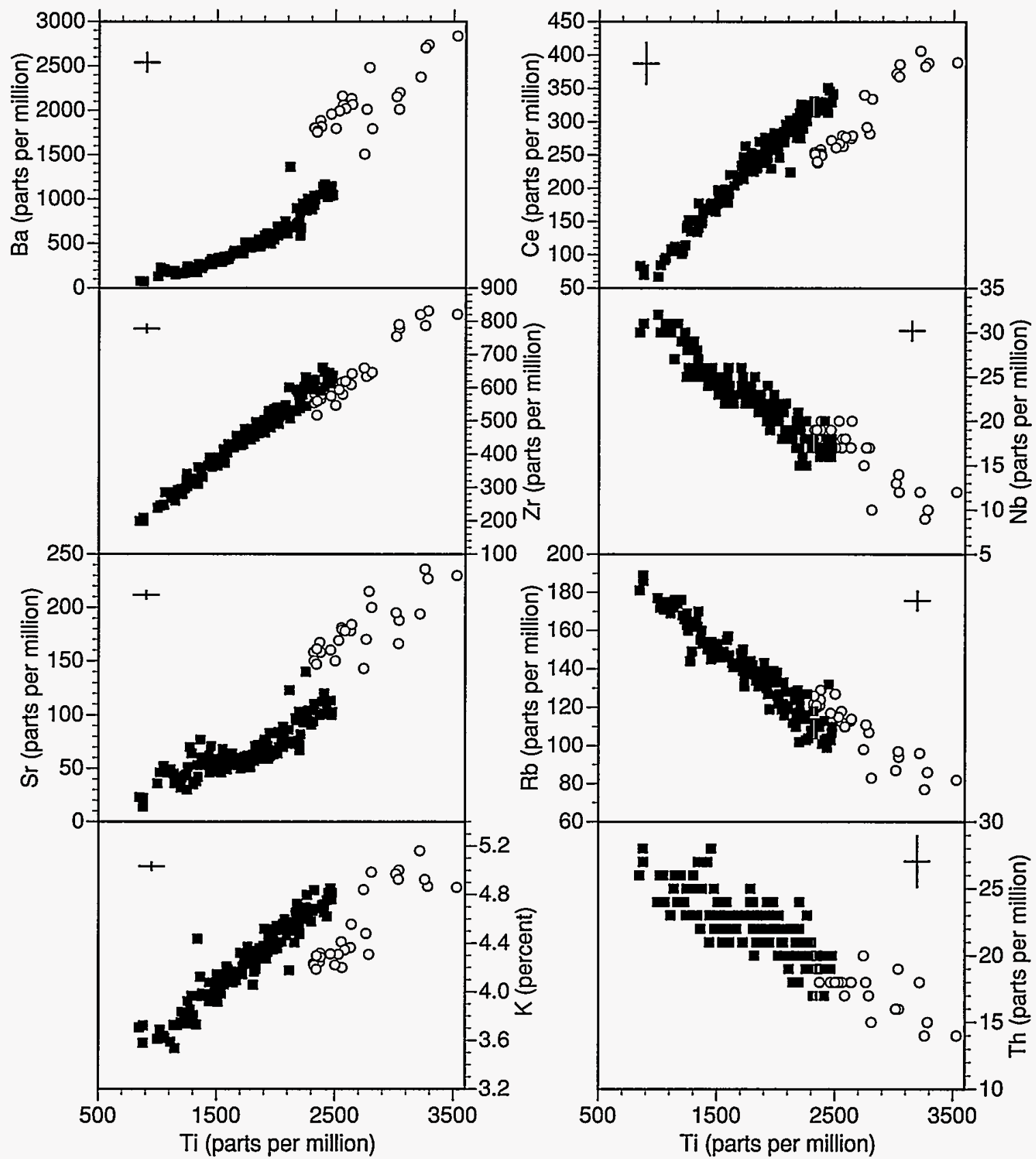

Figure 12. Variations of barium, cerium, zirconium, niobium, strontium, rubidium, potassium, and thorium concentrations as a function of titanium concentration in the Tiva Canyon Tuff upper cliff and caprock samples. The open symbols are caprock samples; the filled symbols are samples of upper cliff. The trends in these elements are typical of differentiation in magmatic systems, although the caprock trends are more diffuse. Typical $2 \sigma$ errors are shown by the crosses. 


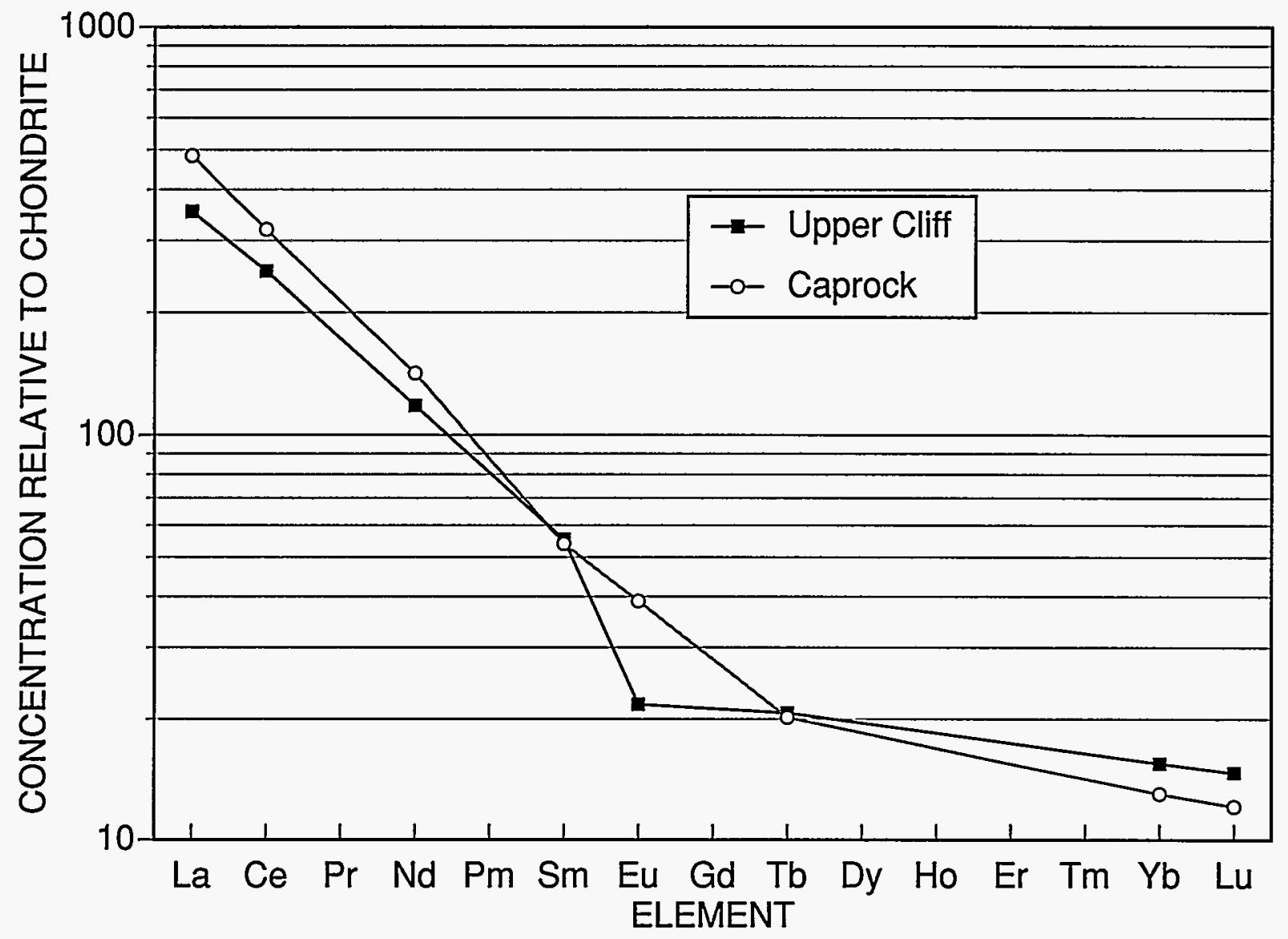

Figure 13. Average rare earth element concentrations (normalized to chondritic [Taylor and McClennan, 1985]) of the upper cliff (filled symbols) and caprock (open symbols) samples. The enrichment in light rare earth elements is typical of felsic igneous rocks. The only element showing a significant difference between upper cliff and caprock is europium, presumably because of plagioclase fractionation. Although the average values for europium are different for upper cliff and caprock, the ranges of the individual analyses overlap.

elements do with titanium contents (fig. 14), indicating that these components do not solely reflect magmatic values. In particular, calcium and $\delta^{18} \mathrm{O}$ values in samples from both zones vary the least systematically with titanium contents, similar to what was observed in samples from the Solitario Canyon section. The trend between calcium and titanium clearly shows the effect of the addition of secondary calcite. Unlike titanium, elements such as sodium, uranium and iron are easily mobilized by post-emplacement, water-rock interactions that could result in the variations shown in figure 14.

Certain elements such as arsenic, selenium, mercury, silver, gold, and copper have been used as pathfinder elements for epithermal precious-metal deposits (Levinson, 1980). For example, the epithermal gold deposit in Fluorspar Canyon near Beatty,
Nevada, has elevated arsenic, silver, and mercury contents that correlate directly with gold concentrations (Greybeck and Wallace, 1991). With few exceptions, however, both the concentrations of typical pathfinder elements and the precious metals themselves are characteristically low in the upper cliff and caprock zone samples (table 7). Selenium, silver, and mercury are below detection limits, and both arsenic and gold are only marginally higher than typical magmatic levels in siliceous igneous rocks (Connors and others, 1993).

\section{Discussion of Results}

The correlations of barium, cerium, zirconium, niobium, strontium, rubidium, potassium, and thorium with titanium in the upper cliff and caprock samples 


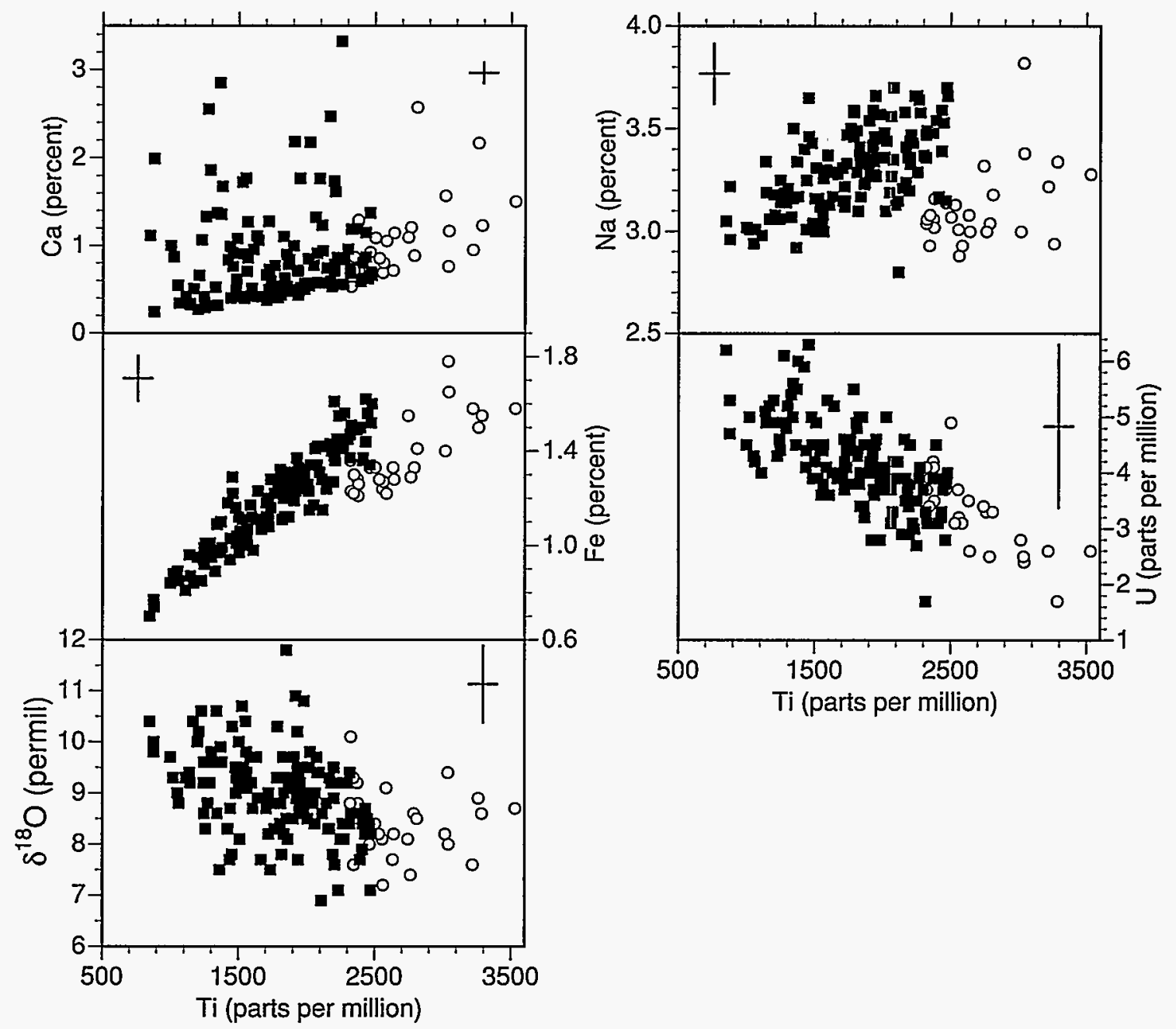

Figure 14. Variation of calcium, sodium, iron, and uranium concentrations and $\delta^{18} \mathrm{O}$ as a function of titanium concentration in the upper cliff (filled symbols) and caprock (open symbols) zones. Note the large amount of scatter, especially in calcium and $\delta^{18} 0$. This scatter is owing to post-eruptive processes. Typical $2 \sigma$ errors are shown by the crosses.

result primarily from magmatic processes. Most of these correlations are also present in rocks of the Solitario Canyon reference section where the variations in each element can also be correlated with stratigraphic position. By analogy, the more extreme variations and poorer correlations with titanium contents for relatively mobile elements (calcium, sodium, iron, and uranium) imply that these elements do not record magmatic effects only, but vary because of secondary processes, such as low-temperature or deuteric alteration, in the same way that they did in samples from the Solitario Canyon reference section. The lack of high concentrations of pathfinder elements or significant variations in elements such as potassium, rubidium, and strontium that are typically mobilized by high-temperature fluids, make hydrothermal alteration or epithermal mineralization of these samples highly unlikely.

As with the tuffs from the Solitario Canyon section, the $\delta^{18} \mathrm{O}$ values of most samples from the upper cliff and caprock zones are higher than estimated original magmatic values and do not correlate with any of the elements measured in this study. Postemplacement processes that can lead to ${ }^{18} \mathrm{O}$ enrichments in siliceous volcanic rocks include lowtemperature hydration of glass, crystallization of quartz and feldspar from deuteric fluids, and addition of pedogenic carbonate and silica. The upper zones of 
Table 7. Chemistry of uncommon trace elements

[All analyses by neutron activation in ppm by weight; < less than; $\mathrm{Au}$ as ppb by weight; $\mathrm{Se}<3 \mathrm{ppm}, \mathrm{Ag}<5 \mathrm{ppm}, \mathrm{Sn}<100 \mathrm{ppm}$, Ir $<5 \mathrm{ppb}$, and $\mathrm{Hg}<1 \mathrm{ppm}$ ]

\begin{tabular}{|c|c|c|c|c|c|c|c|c|c|c|c|}
\hline $\begin{array}{c}\text { Sample site } \\
\text { number }\end{array}$ & $\mathrm{Cr}$ & Co & $\mathrm{NI}$ & $\mathrm{Zn}$ & As & $\mathrm{Br}$ & Mo & Sb & $\mathrm{Ta}$ & $\mathbf{w}$ & $\mathrm{Au}$ \\
\hline 1 & 12 & 1 & $<22$ & 79 & 2.5 & $<0.5$ & $<1$ & 0.4 & 1.1 & $<1$ & $<2$ \\
\hline 2 & $<5$ & $<1$ & $<20$ & 60 & 3.0 & 1.0 & 2 & $<0.1$ & $<0.5$ & $<1$ & 4 \\
\hline 3 & 7 & 3 & $<22$ & 86 & 1.7 & $<0.5$ & $<1$ & 0.2 & $<0.5$ & $<1$ & 3 \\
\hline 4 & $<5$ & $<1$ & $<21$ & 84 & 1.0 & $<0.5$ & $<1$ & 0.3 & $<0.5$ & $<1$ & $<2$ \\
\hline 5 & $<5$ & $<1$ & $<22$ & 100 & 1.4 & $<0.5$ & 3 & 0.3 & $<0.5$ & $<1$ & $<2$ \\
\hline 6 & $<5$ & 2 & $<23$ & $<50$ & 1.4 & $<0.5$ & $<1$ & $<0.1$ & $<0.5$ & $<1$ & $<2$ \\
\hline 7 & $<5$ & $<1$ & $<22$ & 80 & 1.4 & $<0.5$ & 5 & $<0.1$ & $<0.5$ & $<1$ & $<2$ \\
\hline 8 & 5 & $<1$ & $<20$ & 61 & 0.7 & $<0.5$ & $<1$ & 0.2 & 1.1 & $<1$ & $<2$ \\
\hline 9 & 8 & $<1$ & $<22$ & $<50$ & $<0.5$ & $<0.5$ & $<1$ & 0.3 & 1.5 & $<1$ & 3 \\
\hline 10 & $<5$ & $<1$ & $<21$ & 91 & 2.0 & $<0.5$ & $<1$ & 0.3 & $<0.5$ & $<1$ & 2 \\
\hline 11 & $<5$ & 2 & $<21$ & 78 & 2.5 & $<0.5$ & $<1$ & 0.3 & $<0.5$ & $<1$ & 2 \\
\hline 12 & $<5$ & $<1$ & $<20$ & $<50$ & 3.0 & $<0.5$ & $<1$ & 0.1 & 1.2 & $<1$ & $<2$ \\
\hline 13 & $<5$ & 3 & $<24$ & 64 & $<0.5$ & $<0.5$ & $<1$ & $<0.1$ & $<0.5$ & $<1$ & 4 \\
\hline 14 & 13 & $<1$ & $<21$ & 84 & 2.1 & $<0.5$ & 5 & 0.4 & $<0.5$ & $<1$ & $<2$ \\
\hline 15 & 16 & $<1$ & $<23$ & 92 & 1.1 & $<0.5$ & $<1$ & 0.4 & 1.5 & $<1$ & $<2$ \\
\hline 16 & 6 & $<1$ & $<20$ & 81 & 2.2 & $<0.5$ & 4 & 0.2 & 1.1 & $<1$ & 3 \\
\hline 17 & 7 & $<1$ & $<20$ & $<50$ & 1.8 & $<0.5$ & $<1$ & 0.2 & 1.6 & $<1$ & $<2$ \\
\hline 18 & $<5$ & $<1$ & $<20$ & $<50$ & 2.2 & $<0.5$ & 4 & 0.3 & $<0.5$ & $<1$ & $<2$ \\
\hline 19 & $<5$ & $<1$ & $<24$ & $<50$ & 2.1 & $<0.5$ & $<1$ & $<0.1$ & $<0.5$ & $<1$ & $<2$ \\
\hline 20 & 11 & 1 & $<43$ & 67 & 2.4 & $<0.5$ & $<1$ & 0.1 & 0.8 & $<1$ & $<2$ \\
\hline 21 & $<5$ & $<1$ & $<27$ & $<50$ & $<0.5$ & $<0.5$ & $<1$ & $<0.1$ & $<0.5$ & $<1$ & $<2$ \\
\hline 22 & $<5$ & $<1$ & $<20$ & 120 & 2.2 & $<0.5$ & 4 & $<0.1$ & $<0.5$ & $<1$ & $<2$ \\
\hline 23 & 11 & 2 & $<50$ & 89 & 1.7 & $<0.5$ & $<1$ & 0.4 & $<0.5$ & $<1$ & $<2$ \\
\hline 24 & $<5$ & $<1$ & $<51$ & $<50$ & 2.4 & $<0.5$ & $<1$ & $<0.1$ & 0.6 & $<1$ & $<2$ \\
\hline 25 & $<5$ & 1 & $<48$ & 65 & 2.8 & $<0.5$ & $<1$ & 0.4 & $<0.5$ & $<1$ & $<2$ \\
\hline 26 & 7 & 2 & $<22$ & 95 & $<0.5$ & $<0.5$ & 3 & $<0.1$ & 1.2 & $<1$ & 7 \\
\hline 27 & 6 & 2 & $<46$ & 87 & 2.4 & $<0.5$ & $<1$ & $<0.1$ & 1.7 & $<1$ & $<2$ \\
\hline 28 & 7 & $<1$ & 220 & 110 & 1.6 & $<0.5$ & $<1$ & $<0.1$ & $<0.5$ & $<1$ & 2 \\
\hline 29 & 21 & 3 & $<24$ & 100 & 2.3 & $<0.5$ & $<1$ & 0.3 & $<0.5$ & $<1$ & 3 \\
\hline 30 & 11 & $<1$ & $<21$ & 86 & 2.4 & $<0.5$ & $<1$ & 0.3 & $<0.5$ & $<1$ & $<2$ \\
\hline 31 & 15 & $<1$ & $<22$ & $<50$ & 2.1 & $<0.5$ & $<1$ & 0.2 & 1.4 & $<1$ & $<2$ \\
\hline 32 & 13 & 3 & $<23$ & $<50$ & 3.2 & $<0.5$ & $<1$ & $<0.1$ & $<0.5$ & $<1$ & $<2$ \\
\hline
\end{tabular}


N Table 7. Chemistry of uncommon trace elements-Continued

[All analyses by neutron activation in ppm by weight; $<$, less than; $\mathrm{Au}$ as ppb by weight; $\mathrm{Se}<\mathrm{ppm}, \mathrm{Ag}<5 \mathrm{ppm}, \mathrm{Sn}<100 \mathrm{ppm}, \mathrm{I}<5 \mathrm{ppb}$, and $\mathrm{Hg}<1 \mathrm{ppm}$ ]

\begin{tabular}{|c|c|c|c|c|c|c|c|c|c|c|c|}
\hline $\begin{array}{l}\text { Sample site } \\
\text { number }\end{array}$ & $\mathrm{Cr}$ & Co & $\mathrm{Ni}$ & $2 n$ & As & $\mathrm{Br}$ & Mo & Sb & Ta & $w$ & $\mathrm{Au}$ \\
\hline 33 & 6 & $<1$ & $<28$ & 80 & 2.9 & $<0.5$ & $<1$ & 0.6 & $<0.5$ & $<1$ & $<2$ \\
\hline 34 & 6 & $<1$ & $<27$ & 71 & 5.4 & $<0.5$ & 4 & $<0.1$ & $<0.5$ & $<1$ & $<2$ \\
\hline 35 & 8 & 3 & $<28$ & $<50$ & 3.1 & $<0.5$ & $<1$ & 0.5 & $<0.5$ & $<1$ & $<2$ \\
\hline 36 & $<5$ & $<1$ & $<26$ & 100 & 2.6 & $<0.5$ & $<1$ & 0.4 & $<0.5$ & $<1$ & $<2$ \\
\hline 37 & $<5$ & 3 & $<26$ & 69 & 2.1 & $<0.5$ & $<1$ & 0.3 & $<0.5$ & $<1$ & $<2$ \\
\hline 38 & $<5$ & 2 & $<28$ & $<50$ & 0.9 & $<0.5$ & $<1$ & 0.4 & 1.6 & $<1$ & $<2$ \\
\hline 39 & 10 & 2 & $<24$ & 90 & 1.4 & $<0.5$ & 5 & $<0.1$ & $<0.5$ & 14 & $<2$ \\
\hline 40 & 8 & $<1$ & $<29$ & 87 & 1.2 & $<0.5$ & $<1$ & 0.6 & 1.6 & $<1$ & 3 \\
\hline 41 & 9 & 2 & $<29$ & $<50$ & $<0.5$ & $<0.5$ & $<1$ & $<0.1$ & $<0.5$ & $<1$ & $<2$ \\
\hline 42 & $<5$ & $<1$ & $<30$ & $<50$ & 1.5 & $<0.5$ & $<1$ & 0.3 & $<0.5$ & $<1$ & $<2$ \\
\hline 43 & $<5$ & 3 & $<28$ & 93 & 2.1 & $<0.5$ & 3 & 0.3 & 1.4 & $<1$ & 3 \\
\hline 44 & 6 & $<1$ & $<26$ & 67 & 2.7 & $<0.5$ & $<1$ & $<0.1$ & $<0.5$ & $<1$ & $<2$ \\
\hline 45 & 7 & 3 & $<38$ & $<50$ & 2.5 & $<0.5$ & $<1$ & 0.3 & $<0.5$ & $<1$ & $<2$ \\
\hline 46 & $<5$ & $<1$ & $<39$ & 83 & $<0.5$ & $<0.5$ & $<1$ & $<0.1$ & $<0.5$ & $<1$ & $<2$ \\
\hline 47 & 7 & 4 & $<37$ & $<50$ & 2.1 & $<0.5$ & $<1$ & $<0.1$ & 1.8 & $<1$ & $<2$ \\
\hline 48 & $<5$ & 3 & $<33$ & 120 & 2.2 & $<0.5$ & $<1$ & 0.3 & 1.9 & $<1$ & $<2$ \\
\hline 50 & 10 & $<1$ & $<39$ & $<50$ & 1.6 & $<0.5$ & $<1$ & $<0.1$ & $<0.5$ & $<1$ & $<2$ \\
\hline 51 & 12 & 2 & $<27$ & 110 & 5.6 & $<0.5$ & $<1$ & 0.4 & $<0.5$ & $<1$ & $<2$ \\
\hline 52 & 8 & $<1$ & $<39$ & $<50$ & 2.8 & $<0.5$ & $<1$ & 0.2 & $<0.5$ & $<1$ & $<2$ \\
\hline 53 & $<5$ & $<1$ & $<40$ & $<50$ & 2.7 & $<0.5$ & $<1$ & $<0.1$ & $<0.5$ & $<1$ & $<2$ \\
\hline 54 & 8 & 1 & $<21$ & 61 & 5.8 & $<0.5$ & $<1$ & 0.2 & 1.9 & $<1$ & 3 \\
\hline 55 & 5 & 3 & $<28$ & $<50$ & 3.3 & $<0.5$ & $<1$ & 0.4 & $<0.5$ & $<1$ & 6 \\
\hline 56 & 9 & 3 & $<27$ & $<50$ & 2.7 & $<0.5$ & 4 & 0.5 & 1.7 & $<1$ & $<2$ \\
\hline 57 & 7 & 3 & $<38$ & $<50$ & 3.4 & $<0.5$ & $<1$ & 0.3 & $<0.5$ & $<1$ & 16 \\
\hline 58 & 9 & $<1$ & $<29$ & $<50$ & 2.8 & $<0.5$ & $<1$ & 0.3 & $<0.5$ & $<1$ & $<2$ \\
\hline 59 & $<5$ & 3 & $<30$ & 130 & 1.9 & $<0.5$ & $<1$ & 1.9 & 1.9 & $<1$ & $<2$ \\
\hline 60 & $<5$ & 2 & $<30$ & 77 & 1.3 & $<0.5$ & $<1$ & $<0.1$ & $<0.5$ & $<1$ & $<2$ \\
\hline 61 & 13 & 2 & $<21$ & 100 & 1.4 & $<0.5$ & $<1$ & 0.2 & 1.2 & $<1$ & 3 \\
\hline 62 & $<5$ & $<1$ & $<20$ & 89 & 0.9 & $<0.5$ & 7 & 0.3 & 1.2 & $<1$ & $<2$ \\
\hline 63 & 12 & 2 & $<20$ & 81 & 1.7 & $<0.5$ & 3 & 0.3 & 1.6 & $<1$ & $<2$ \\
\hline 64 & 6 & $<1$ & $<38$ & 130 & $<0.5$ & $<0.5$ & $<1$ & 0.5 & $<0.5$ & $<1$ & 5 \\
\hline 65 & $<5$ & $<1$ & $<21$ & $<50$ & 2.4 & $<0.5$ & $<1$ & 0.3 & 1.6 & $<1$ & 2 \\
\hline 66 & 5 & $<1$ & $<39$ & $<50$ & 1.1 & $<0.5$ & $<1$ & $<0.1$ & $<0.5$ & $<1$ & $<2$ \\
\hline 67 & 11 & 2 & $<22$ & 68 & 1.4 & $<0.5$ & $<1$ & $<0.1$ & $<0.5$ & $<1$ & 3 \\
\hline
\end{tabular}


Table 7. Chemistry of uncommon trace elements - Continued

[All analyses by neutron activation in ppm by weight; $<$, less than; Au as ppb by weight; $\mathrm{Se}<\mathrm{ppm}, \mathrm{Ag}<5 \mathrm{ppm}, \mathrm{Sn}<100 \mathrm{ppm}$, Ir $<5 \mathrm{ppb}$, and $\mathrm{Hg}<1 \mathrm{ppm}$ ]

\begin{tabular}{|c|c|c|c|c|c|c|c|c|c|c|c|}
\hline $\begin{array}{c}\text { Sample site } \\
\text { number }\end{array}$ & $\mathrm{Cr}$ & Co & $\mathbf{N I}$ & $\mathrm{Zn}$ & As & $\mathrm{Br}$ & Mo & Sb & $\mathrm{Ta}$ & w & $\mathrm{Au}$ \\
\hline 68 & 5 & $<1$ & $<22$ & $<50$ & 0.9 & $<0.5$ & $<1$ & 0.3 & $<0.5$ & $<1$ & 2 \\
\hline 69 & 8 & $<1$ & $<21$ & $<50$ & $<0.5$ & $<0.5$ & $<1$ & 0.3 & $<0.5$ & $<1$ & $<2$ \\
\hline 70 & 6 & 2 & $<20$ & 87 & $<0.5$ & $<0.5$ & 2 & 0.2 & $<0.5$ & $<1$ & 2 \\
\hline 71 & $<5$ & 2 & $<20$ & 78 & $<0.5$ & $<0.5$ & $<1$ & 0.3 & 1.1 & $<1$ & $<2$ \\
\hline 72 & $<5$ & $<1$ & $<26$ & $<50$ & 4.5 & $<0.5$ & 4 & 0.5 & $<0.5$ & $<1$ & $<2$ \\
\hline 73 & $<5$ & 4 & $<33$ & 93 & $<0.5$ & $<0.5$ & $<1$ & $<0.1$ & $<0.5$ & $<1$ & 3 \\
\hline 74 & 8 & $<1$ & 160 & 60 & 3.5 & $<0.5$ & 2 & 0.3 & $<0.5$ & $<1$ & $<2$ \\
\hline 75 & 9 & 1 & $<20$ & 99 & 1.2 & $<0.5$ & $<1$ & 0.3 & $<0.5$ & $<1$ & 3 \\
\hline 76 & 8 & $<1$ & $<35$ & $<50$ & $<0.5$ & $<0.5$ & $<1$ & 0.3 & 1.8 & $<1$ & 3 \\
\hline 77 & 14 & $<1$ & $<20$ & 98 & $<0.5$ & $<0.5$ & 4 & 0.4 & 1.8 & $<1$ & $<2$ \\
\hline 78 & 7 & 2 & $<20$ & 82 & $<0.5$ & $<0.5$ & 3 & $<0.1$ & $<0.5$ & $<1$ & $<2$ \\
\hline 79 & 19 & 2 & $<20$ & 62 & 1.4 & $<0.5$ & 5 & $<0.1$ & $<0.5$ & $<1$ & 6 \\
\hline 80 & 5 & $<1$ & $<32$ & $<50$ & $<0.5$ & $<0.5$ & $<1$ & 0.3 & $<0.5$ & $<1$ & $<2$ \\
\hline 81 & 6 & 2 & 120 & $<50$ & $<0.5$ & $<0.5$ & $<1$ & 0.4 & $<0.5$ & $<1$ & $<2$ \\
\hline 82 & 16 & $<1$ & 180 & 86 & $<0.5$ & $<0.5$ & 2 & $<0.1$ & $<0.5$ & $<1$ & 5 \\
\hline 83 & $<5$ & $<1$ & $<20$ & 96 & 3.7 & $<0.5$ & 5 & 0.4 & 1.2 & 2 & 4 \\
\hline 84 & 6 & $<1$ & $<32$ & $<50$ & 2.4 & $<0.5$ & $<1$ & $<0.1$ & $<0.5$ & $<1$ & $<2$ \\
\hline 85 & $<5$ & $<1$ & $<29$ & $<50$ & 2.2 & $<0.5$ & $<1$ & 0.3 & 2.7 & $<1$ & 2 \\
\hline 86 & 11 & $<1$ & $<20$ & 80 & 3.1 & 0.7 & $<1$ & 0.4 & 0.8 & $<1$ & $<2$ \\
\hline 87 & 7 & $<1$ & $<28$ & $<50$ & $<0.5$ & $<0.5$ & $<1$ & $<0.1$ & $<0.5$ & 3 & $<2$ \\
\hline 88 & $<5$ & 1 & $<20$ & 58 & 6.5 & $<0.5$ & $<1$ & 0.7 & 1.0 & $<1$ & $<2$ \\
\hline 89 & 7 & 1 & $<20$ & 100 & 0.9 & $<0.5$ & $<1$ & $<0.1$ & 1.1 & 110 & $<2$ \\
\hline 90 & 7 & $<1$ & $<35$ & 91 & $<0.5$ & $<0.5$ & 2 & $<0.1$ & $<0.5$ & $<1$ & $<2$ \\
\hline 91 & 11 & 2 & $<20$ & 63 & $<0.5$ & $<0.5$ & $<1$ & 0.3 & $<0.5$ & $<1$ & $<2$ \\
\hline 92 & $<5$ & 3 & $<30$ & 99 & 2.5 & $<0.5$ & $<1$ & $<0.1$ & $<0.5$ & $<1$ & $<2$ \\
\hline 93 & $<5$ & $<1$ & $<33$ & 120 & 2.4 & $<0.5$ & $<1$ & 0.4 & 1.7 & $<1$ & $<2$ \\
\hline 94 & $<5$ & $<1$ & $<32$ & 99 & 2.2 & $<0.5$ & 9 & 0.3 & $<0.5$ & $<1$ & $<2$ \\
\hline 95 & 7 & $<1$ & $<30$ & 90 & 2.8 & $<0.5$ & $<1$ & $<0.1$ & $<0.5$ & $<1$ & $<2$ \\
\hline 96 & $<5$ & $<1$ & $<31$ & $<50$ & 2.1 & $<0.5$ & $<1$ & 0.3 & $<0.5$ & $<1$ & $<2$ \\
\hline 97 & 9 & $<1$ & $<32$ & $<50$ & 2.7 & $<0.5$ & $<1$ & 0.9 & $<0.5$ & $<1$ & $<2$ \\
\hline 98 & 7 & $<1$ & $<22$ & 63 & 7.3 & 1.8 & $<1$ & 0.7 & $<0.5$ & $<1$ & $<2$ \\
\hline 99 & 8 & 2 & $<26$ & $<50$ & 1.9 & $<0.5$ & 6 & $<0.1$ & 2.4 & $<1$ & $<2$ \\
\hline 100 & 6 & 3 & $<31$ & 110 & $<0.5$ & $<0.5$ & 3 & 0.4 & $<0.5$ & $<1$ & $<2$ \\
\hline 101 & 10 & $<1$ & $<27$ & 51 & $<0.5$ & $<0.5$ & $<1$ & 0.4 & $<0.5$ & $<1$ & $<2$ \\
\hline
\end{tabular}


\$ Table 7. Chemistry of uncommon trace elements-Continued

[All analyses by neutron activation in ppm by weight; $<$, less than; Au as ppb by weight; $\mathrm{Se}<3 \mathrm{ppm}, \mathrm{Ag}<5 \mathrm{ppm}, \mathrm{Sn}<100 \mathrm{ppm}$, Ir $<5 \mathrm{ppb}$, and $\mathrm{Hg}<1 \mathrm{ppm}$ ]

\begin{tabular}{|c|c|c|c|c|c|c|c|c|c|c|c|}
\hline $\begin{array}{l}\text { Sample site } \\
\text { number }\end{array}$ & $\mathrm{Cr}$ & Co & NI & $\mathbf{Z n}$ & As & $\mathrm{Br}$ & Mo & $\mathbf{S b}$ & Ta & $w$ & Au \\
\hline 102 & 12 & $<1$ & $<24$ & 80 & 3.9 & $<0.5$ & $<1$ & 0.3 & 1.7 & $<1$ & $<2$ \\
\hline 103 & 10 & $<1$ & 120 & $<50$ & 3.5 & $<0.5$ & $<1$ & 0.3 & 1.2 & $<1$ & $<2$ \\
\hline 104 & 15 & $<1$ & $<21$ & $<50$ & 3.4 & $<0.5$ & $<1$ & 0.5 & $<0.5$ & $<1$ & $<2$ \\
\hline 105 & 6 & $<1$ & $<23$ & 52 & 3.0 & $<0.5$ & $<1$ & 0.3 & $<0.5$ & $<1$ & $<2$ \\
\hline 106 & 7 & $<1$ & $<21$ & 64 & 3.7 & $<0.5$ & 2 & 0.3 & 1.9 & $<1$ & $<2$ \\
\hline 107 & 10 & $<1$ & $<23$ & 70 & 3.4 & 1.4 & $<1$ & 0.3 & 1.6 & $<1$ & $<2$ \\
\hline 108 & 7 & $<1$ & $<22$ & $<50$ & 3.9 & $<0.5$ & $<1$ & 0.3 & 1.5 & $<1$ & $<2$ \\
\hline 110 & 6 & $<1$ & $<21$ & 73 & 7.3 & $<0.5$ & 5 & 0.3 & 1.4 & $<1$ & $<2$ \\
\hline 111 & 7 & $<1$ & $<27$ & 100 & 2.5 & $<0.5$ & $<1$ & 0.3 & 1.1 & $<1$ & $<2$ \\
\hline 112 & 9 & $<1$ & $<27$ & 79 & 2.9 & $<0.5$ & $<1$ & 0.3 & $<0.5$ & $<1$ & $<2$ \\
\hline 113 & $<5$ & 2 & $<27$ & 67 & 1.9 & $<0.5$ & $<1$ & $<0.1$ & $<0.5$ & $<1$ & $<2$ \\
\hline 114 & 7 & $<1$ & $<22$ & 65 & 1.9 & $<0.5$ & $<1$ & 0.4 & 1.2 & $<1$ & $<2$ \\
\hline 115 & 13 & 2 & $<24$ & 80 & 3.5 & $<0.5$ & $<1$ & $<0.1$ & $<0.5$ & $<1$ & $<2$ \\
\hline 116 & 11 & $<1$ & 120 & $<50$ & 2.4 & $<0.5$ & $<1$ & $<0.1$ & $<0.5$ & $<1$ & $<2$ \\
\hline 117 & 11 & $<1$ & $<22$ & $<50$ & 2.4 & $<0.5$ & $<1$ & 0.2 & 1.7 & 3 & $<2$ \\
\hline 118 & $<5$ & 3 & $<25$ & $<50$ & 3.4 & $<0.5$ & $<1$ & $<0.1$ & $<0.5$ & $<1$ & $<2$ \\
\hline 119 & $<5$ & 1 & $<22$ & 90 & 4.9 & $<0.5$ & $<1$ & 0.4 & 1.4 & $<1$ & $<2$ \\
\hline 120 & 10 & $<1$ & $<26$ & 68 & 3.4 & $<0.5$ & $<1$ & 0.3 & $<0.5$ & $<1$ & $<2$ \\
\hline 121 & $<5$ & $<1$ & $<27$ & $<50$ & $<0.5$ & $<0.5$ & $<1$ & 0.5 & $<0.5$ & $<1$ & $<2$ \\
\hline 122 & 5 & $<1$ & $<25$ & $<50$ & 2.6 & $<0.5$ & $<1$ & $<0.1$ & 1.6 & $<1$ & 3 \\
\hline 123 & 9 & $<1$ & $<28$ & 110 & 3.4 & $<0.5$ & $<1$ & 0.4 & $<0.5$ & $<1$ & $<2$ \\
\hline 124 & 7 & 2 & $<20$ & 76 & 7.5 & 2.1 & 4 & 0.6 & 1.2 & $<1$ & $<2$ \\
\hline 125 & 10 & $<1$ & $<20$ & 90 & 2.7 & $<0.5$ & $<1$ & 0.2 & 1.5 & $<1$ & $<2$ \\
\hline 126 & $<5$ & $<1$ & $<20$ & 120 & 10.0 & 1.5 & $<1$ & 0.4 & $<0.5$ & 29 & $<2$ \\
\hline 127 & 14 & $<1$ & $<20$ & $<50$ & 3.1 & $<0.5$ & $<1$ & 0.2 & $<0.5$ & $<1$ & $<2$ \\
\hline 128 & 10 & 1 & $<21$ & 57 & 1.8 & $<0.5$ & $<1$ & 0.3 & 0.7 & $<1$ & $<2$ \\
\hline 129 & 5 & 1 & $<20$ & 94 & $<0.5$ & $<0.5$ & 3 & 0.2 & 1.5 & $<1$ & $<2$ \\
\hline 130 & 7 & 1 & $<23$ & 97 & $<0.5$ & $<0.5$ & 3 & $<0.1$ & 1.0 & $<1$ & $<2$ \\
\hline 131 & 7 & 3 & $<22$ & 58 & 1.9 & $<0.5$ & 3 & 0.2 & $<0.5$ & $<1$ & 2 \\
\hline 132 & 5 & 2 & $<27$ & 110 & $<0.5$ & $<0.5$ & 3 & $<0.1$ & 1.3 & $<1$ & $<2$ \\
\hline 133 & $<5$ & $<1$ & $<26$ & 67 & 1.4 & $<0.5$ & $<1$ & 0.2 & $<0.5$ & $<1$ & $<2$ \\
\hline 134 & 9 & $<1$ & $<33$ & 100 & $<0.5$ & $<0.5$ & $<1$ & $<0.1$ & 1.8 & $<1$ & 5 \\
\hline 135 & 10 & $<1$ & $<24$ & 67 & 1.4 & $<0.5$ & $<1$ & $<0.1$ & $<0.5$ & $<1$ & $<2$ \\
\hline 136 & 6 & $<1$ & $<22$ & 94 & 1.4 & $<0.5$ & 4 & $<0.1$ & $<0.5$ & $<1$ & 4 \\
\hline
\end{tabular}


Table 7. Chemistry of uncommon trace elements - Continued

[All analyses by neutron activation in ppm by weight, $<$ less than; Au as ppb by weight; Se $<\mathrm{ppm}, \mathrm{Ag}<5 \mathrm{ppm}, \mathrm{Sn}<100 \mathrm{ppm}$, Ir $<\mathrm{ppb}$, and $\mathrm{Hg}<1 \mathrm{ppm}$ ]

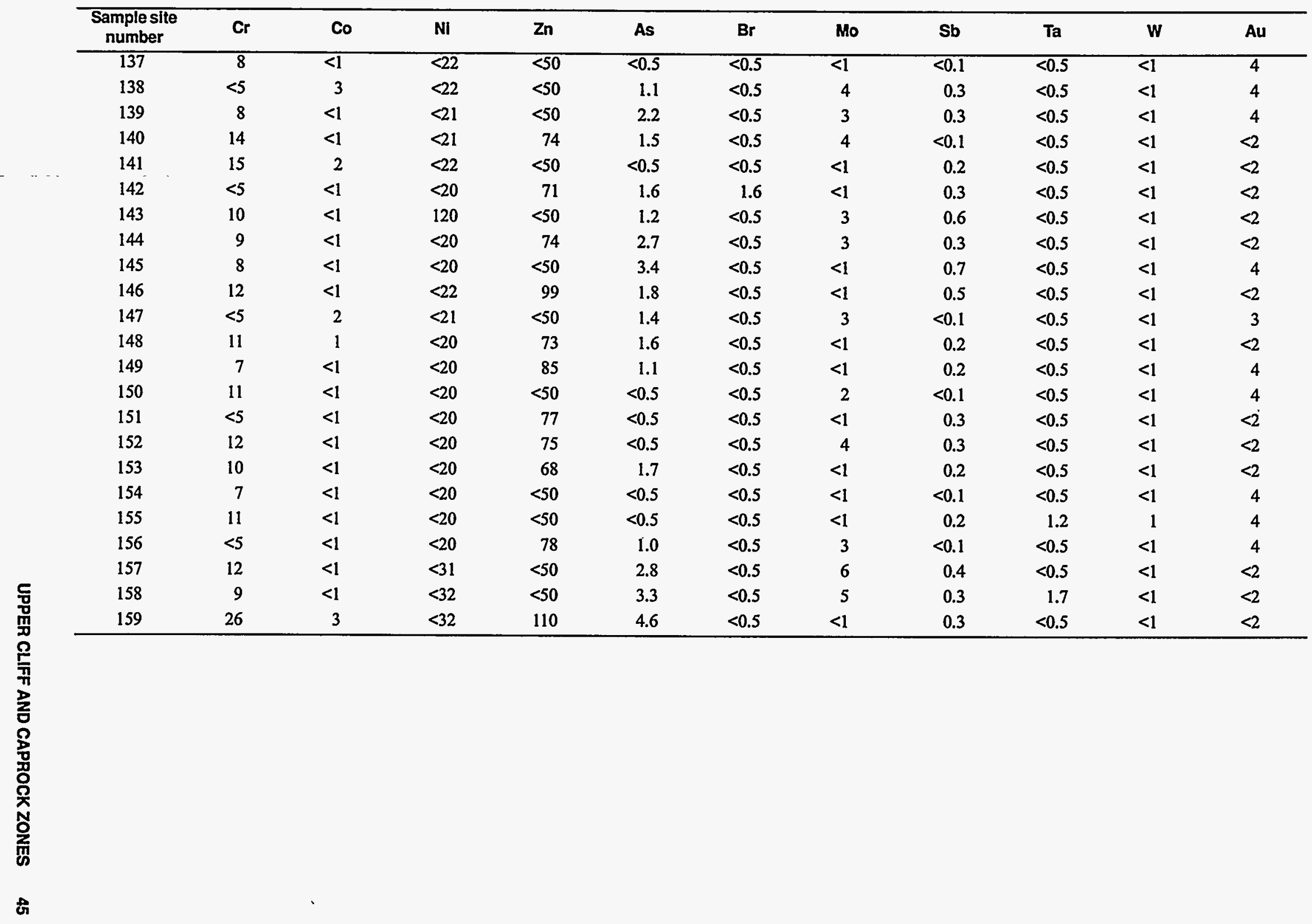


the Tiva Canyon Tuff are devitrified, contain biotite phenocrysts, and have vapor-phase minerals lining the pumice cavities (Singer and others, 1994). Hightemperature devitrification of glass shards prevented subsequent low-temperature glass hydration. However, post-emplacement recrystallization of the tuffs and alteration by deuteric fluids would have resulted in slight and variable enrichments in ${ }^{18} \mathrm{O}$, as proposed for some of the samples from the Solitario Canyon section. Deuteric alteration would have little effect on the distribution of most other elements and would be enhanced in zones that cooled slowly. The lack of correlations between $\delta^{18} \mathrm{O}$ values and other elements, fault zones; or specific areas are further evidence that increases in ${ }^{18} \mathrm{O}$ in the upper cliff and caprock samples are unrelated to specific fluid events other than those associated with emplacement of the unit. The absence of any low $\delta^{18} \mathrm{O}$ values indicates that hydrothermal alteration by meteoric waters, either during or after emplacement, was minimal (Taylor, 1974).

The addition of small quantities of lowtemperature carbonate and silica, which have high $\delta^{18} \mathrm{O}$ values in excess of $+19 \%$ (Vaniman and Whelan, 1994), to the upper cliff and caprock samples cannot be totally discounted as a process that elevates the whole-rock $\delta^{18} \mathrm{O}$ values. However, there is no correlation between $\delta^{18} \mathrm{O}$ values and calcium contents as would be expected if pedogenic calcite were the source of the high $\delta^{18} \mathrm{O}$ values. Small quantities of pedogenic carbonate may have resulted in elevation of the original calcium contents, but the effect on wholerock $\delta^{18} \mathrm{O}$ values is minimal as discussed above for the samples from the Solitario Canyon section. The addition of low-temperature silica is more difficult to assess, although none was observed during petrographic examination. Late-stage fracture coatings of chalcedony are present in areas of the upper cliff zone, but these areas were avoided during sampling. The $\delta^{18} \mathrm{O}$ value of one such coating from the sample at map location 108 (fig. 2) is $+28 \%$. The adjacent tuff has a value of $+9.4 \%$, indicating that infiltration of latestage silica, if present, is minimal.

\section{CONCLUSIONS}

Most of the variations in the chemical compositions of the high-silica rhyolite and quartz latite from the Tiva Canyon Tuff reflect magmatic processes. Only elements such as sodium, calcium, and uranium that can be easily mobilized by low-temperature fluids appear to have been affected by post-eruptive fluidrock interactions. However, these interactions are restricted to deuteric alteration, in which magmatic fluids precipitated silica and feldspar, and to lowtemperature alteration, in which silica and carbonate were precipitated from meteoric waters. None of the samples of the Tiva Canyon Tuff have high concentrations of trace elements such as arsenic, silver, mercury, or gold that would indicate hydrothermal alteration or epithermal mineralization.

The $\delta^{18} \mathrm{O}$ values of whole-rock samples of the Tiva Canyon Tuff range from +6.9 to $+11.8 \%$. Most are higher than the presumed magmatic values of +6 to $+8 \%$, but none are lower. Whole-rock $\delta^{18} \mathrm{O}$ values have been elevated primarily as a result of deuteric alteration during cooling of the ash-flow unit. Minor addition of carbonate and silica from low-temperature meteoric waters and low-temperature hydration of volcanic glass, where not devitrified, also may have contributed to the high $\delta^{18} \mathrm{O}$ values in some samples.

Most significant from a mineral resources perspective is the lack of similarity between both oxygen isotopic compositions and pathfinder elements in proximal mineralized areas and those measured in this study. O'Neil and Silberman (1974) reported $\delta^{18} \mathrm{O}$ values less than 5 permil for silicate minerals from epithermal gold and silver deposits in Nevada and attributed such low values to precipitation from hydrothermal meteoric waters. Quartz from the Bullfrog gold mine near Beatty and the Goldfield gold mine near Tonopah have $\delta^{18} \mathrm{O}$ values of 5.2 and -1.2 permil, respectively. These values are significantly lower than any of those measured in samples from the Tiva Canyon Tuff, indicating an absence of hydrothermal alteration and significant epithermal mineralization in this part of the volcanic section at Yucca Mountain. 


\section{REFERENCES CITED}

Benson, L.V., and McKinley, P.W., 1985, Chemical composition of ground water in the Yucca Mountain area, Nevada, 1971-1984: U.S. Geological Survey OpenFile Report 85-484, 10 p.

Broxton, D.E., Warren, R.G., and Byers, F.M., 1989, Chemical and mineralogic trends within the Timber Mountain-Oasis Valley caldera complex, NevadaEvidence for multiple cycles of chemical evolution in a long-lived silicic magma system: Journal of Geophysical Research, v. 94, no. B5, p. 5961-5985.

Buesch, D.C., Spengler, R.W., Moyer, T., and Geslin, J., 1996, Revised stratigraphic nomenclature and macroscopic identification of lithostratigraphic units of the Paintbrush Group exposed at Yucca Mountain, Nevada: U.S. Geological Survey Open-File Report 94-469, 45 p.

Castor, S.B., Feldman, S.C., and Tingley, J.V., 1990, Mineral evaluation of the Yucca Mountain addition, Nye County, Nevada: Nevada Bureau of Mines and Geology Open-File Report 90-4, 80 p.

Connors, K.A., Noble, D.C., Bussey, S.D., and Weiss, S.I., 1993, Initial gold contents of silicic volcanic rocks-Bearing on the behavior of gold in magmatic systems: Geology, v. 21, no. 10, p. 937-940.

Cornwall, H.R., 1972, Geology and mineral deposits of southern Nye County, Nevada: Nevada Bureau of Mines and Geology Bulletin 77, 49 p.

Criss, R.E., and Taylor, H.P., Jr., 1986, Meteorichydrothermal systems, in Valley, J.W., Taylor, H.P., Jr., and O'Neil, J.R., eds., Stable isotopes in high temperature geological processes: Mineralogical Society of America, Reviews in Mineralogy, v. 16, p. 373-424.

Ewers, G.R., Mackenzie, D.E., Wyborn, D., Oversby, B.S., McPhie, J., and Andrew, A.S., 1994, Regional ${ }^{18} \mathrm{O}$ depletions in igneous rocks from the northern Drummond Basin, Queensland, Australia, and their implications for epithermal gold mineralization: Economic Geology, v. 89, no. 3, p. 662-673.

Farmer, G.L., Broxton, D.E., Warren, R.G., and Pickthorn, W., 1991, Nd, Sr, and O isotopic variations in the metaluminous ash-flow tuffs and related volcanic rocks at the Timber Mountain/Oasis Valley caldera complex, SW Nevada-Implications for the origin of large-volume silicic magma bodies: Contributions to Mineralogy and Petrology, v. 109, no. 1, p. 53-68.

Ferriz, H., and Mahood, G.A., 1987, Strong compositional zonation in a silicic magmatic system-Los Humeros, Mexican neovolcanic belt: Journal of Petrology, v. 28, no. 1-3, p. 171-209.
Flood, T.P., Vogel, T.A., and Schuraytz, B.C., 1989, Chemical evolution of a magmatic system-The Paintbrush Tuff, southwest Nevada volcanic field: Journal of Geophysical Research, v. 94, no. B5, p. 5943-5960.

Friedman, I., and Smith, R.L., 1960, A new dating method using obsidian-Part I, the development of the method: American Antiquity, v. 25, p. 476-522.

Greybeck, J.D., and Wallace, A.B., 1991, Gold mineralization at Fluorspar Canyon near Beatty, Nye County, Nevada, in Raines, G.L., Lisle, R.E., Schafer, R.W., and Wilkinson, W.H., eds., Geology and ore deposits of the Great Basin: Reno, Geological Society of Nevada, p. 935-946.

Grow, J.A., Barker, C.E., and Harris, A.G., 1994, Oil and gas exploration near Yucca Mountain, southern Nevada, in High Level Radioactive Waste Management, 5th [Proceedings]: La Grange Park, Ill., American Nuclear Society, p. 1298-1315.

Halliday, A.N., Fallick, A.E., Hutchinson, J., and Hildreth, W., 1984, A Nd, Sr and O isotopic investigation into the causes of chemical and isotopic zonation in the Bishop Tuff, California: Earth and Planetary Science Letters, v. 68, no. 3, p. 379-391.

Hildreth, W., 1979, The Bishop Tuff-Evidence for the origin of compositional zonation in silicic magma chambers: Geological Society of America Special Paper 180, p. 43-75.

1981, Gradients in silicic magma chambers-Implications for lithospheric magmatism: Journal of Geophysical Research, v. 86, no. 11-12, p. 10153-10192.

Hildreth, W., Christiansen, R.L., and O'Neil, J.R., 1984, Catastrophic isotopic modification of rhyolitic magma at times of caldera subsidence; Yellowstone Plateau volcanic field: Journal of Geophysical Research, v. 89, no. B10, p. 8339-8369.

Hildreth, W., and Michael, P.J., 1983, Comment and reply on "Chemical differentiation of the Bishop Tuff and other high-silica magmas through crystallization processes": Geology, v. 11, no. 10, p. 622-624.

Levinson, A.A., 1980, Introduction to exploration geochemistry: Wilmette, Ill., Applied Publishing, 924 p.

Lipman, P.W., Christiansen, R.L., and O'Connor, J.T., 1966, A compositionally zoned ash-flow sheet in southern Nevada: U.S. Geological Survey Open-File Report 524-F, p. F1-F47.

Lipman, P.W., and Friedman, I., 1975, Interaction of meteoric water with magma-An oxygen-isotope study of ash-flow sheets from southern Nevada: Geological Society of America Bulletin, v. 86, no. 5, p. 695-702.

McCulloch, M.T., Kyser, T.K., Woodhead, J.D., and Kinsley, L., 1994, Pb-Sr-Nd-O isotopic constraints on the origin of rhyolites from the Taupo volcanic zone of New Zealand-Evidence for assimilation followed by 
fractionation from basalt: Contributions to Mineralogy and Petrology, v. 115, no. 1, p. 303-312.

Neymark, L.A., Marshall, B.D., Kwak, L.M., Futa, K., and Mahan, S.A., 1995, Geochemical and Pb, Sr, and O isotopic study of the Tiva Canyon Tuff and Topopah Spring Tuff in the vicinity of Yucca Mountain, Nye County, Nevada: U.S. Geological Survey Open-File Report 95-134, $17 \mathrm{p}$.

O'Neil, J.R., and Silberman, M.L., 1974, Stable isotope relations in epithermal $\mathrm{Au}-\mathrm{Ag}$ deposits: Economic Geology, v. 69, no. 6, p. 902-909.

O'Neill, J.M., Whitney, J.W., and Hudson, M.R., 1992, Photogeologic and kinematic analysis of lineaments at Yucca Mountain, Nevada - Implications for strike-slip faulting and oroclinal bending: U.S. Geological Survey Open-File Report 91-623, 24 p.

Ohmoto, H., 1986, Stable isotope geochemistry of ore deposits, in Valley, J.W., Taylor, H.P., Jr., and O'Neil, J.R., eds., Stable isotopes in high temperature geological processes: Mineralogical Society of America, Reviews in Mineralogy, v. 16, p. 491-559.

Pearce, J.A., and Cann, J.R., 1973, Tectonic setting of basic volcanic rocks determined using trace element analysis: Earth and Planetary Science Letters, v. 19, no. 2, p. 290-300.

Peterman, Z.E., and Futa, K., 1996, Geochemistry of core samples of the Tiva Canyon Tuff from drill hole UE-25 NRG\#3, Yucca Mountain, Nevada: U.S. Geological Survey Open-File Report, $19 \mathrm{p}$.

Peterman, Z.E., Widmann, B.L., Marshall, B.D., Aleinikoff, J.N., Futa, K., and Mahan, S.A., 1994, Isotopic tracers of gold deposition in Paleozoic limestones, southern Nevada, in High Level Radioactive Waste Management, 5th [Proceedings]: La Grange Park, Ill., American Nuclear Society, p. 1316-1323.

Ransome, F.L., 1907, Preliminary account of Goldfield, Bullfrog, and other mining districts in southern Nevada: U.S. Geological Survey Bulletin 303, 98 p. 1910 , Geology and ore deposits of the Bullfrog District, Nevada: U.S. Geological Survey Bulletin $407,130 \mathrm{p}$.

Romberger, S.B., 1988, Disseminated gold deposits, in Roberts, R.G., and Sheahan, P.A., eds., Ore Deposit Models: Geoscience Canada Reprint Series, v. 3, p. 21-30.

-1993, A model for bonanza gold deposits, in Sheahan, P.A., and Cherry, M.E., eds., Ore Deposit Models: Geoscience Canada Reprint Series, v. 6, p. 77-86.

Ross, C.S., and Smith, R.L., 1955, Water and other volatiles in volcanic glasses: American Mineralogist, v. 40, no. 11-12, p. 1071-1089.
-1961, Ash-flow tuffs-Their origin and geologic relations and identification: U.S. Geological Survey Open-File Report 366, 81 p.

Sawyer, D.A., Fleck, R.J., Lanphere, M.A., Warren, R.G., Broxton, D.E., and Hudson, M.R., 1994, Episodic volcanism in the Miocene southwest Nevada volcanic field-Stratigraphic revisions, ${ }^{40} \mathrm{Ar} /{ }^{39} \mathrm{Ar}$ geochronologic framework, and implications for magmatic evolution: Geological Society of America Bulletin, v. 106, no. 10, p. 1304-1318.

Schuraytz, B.C., Vogel, T.A., and Younker, L.W., 1989, Evidence for dynamic withdrawal from a layered magma body - The Topopah Spring Tuff, southwestern Nevada: Journal of Geophysical Research, v. 94, no. B5, p. 5925-5942.

Scott, R.B., and Bonk, J., 1984, Preliminary geologic map of Yucca Mountain, Nye County, Nevada, with geologic sections: U.S. Geological Survey Open-File Report 84-494, scale 1:12,000.

Singer, F.R., Byers, F.M., Jr., Widmann, B.L., and Dickerson, R.P., 1994, Petrographic and geochemical characteristics of a section through the Tiva Canyon Tuff at Antler Ridge, Yucca Mountain, Nevada, in High Level Radioactive Waste Management, 5th [Proceedings]: La Grange Park, Ill., American Nuclear Society, p. 1869-1879.

Smith, R.L., 1960, Zones and zonal variations in welded ash flows: U.S. Geological Survey Open-File Report 354-F, p. 149-159.

Spengler, R.W., and Fox K.R., Jr., 1989, Stratigraphic and structural framework of Yucca Mountain, Nevada: Radioactive Waste Management and the Nuclear Fuel Cycle, v. 13, p. 21-36.

Stuckless, J.S., and O'Neil, J.R., 1973, Petrogenesis of the Superstition-Superior volcanic area as inferred from strontium- and oxygen-isotope studies: Geological Society of America Bulletin, v. 84, no. 6, p. 1987-1998.

Szabo, B.J., and Kyser, T.K., 1990, Ages and stable isotope compositions of secondary calcite and opal in drill cores from Tertiary volcanic rocks of the Yucca Mountain area, Nevada: Geological Society of America Bulletin, v. 102, no. 12, p. 1714-1719.

Taylor, B.E., 1991, Degassing of Obsidian Dome rhyolite, Inyo volcanic chain, California, in Taylor, H.P., Jr., O’Neil, J.R., and Kaplan, I.R., eds., Stable isotope geochemistry-A tribute to Samuel Epstein: San Antonio, The Geochemical Society, p. 339-353.

Taylor, H.P., Jr., 1968, The oxygen isotope geochemistry of igneous rocks: Contributions to Mineralogy and Petrology, v. 19, no. 1, p. 1-71. 
-1974, The application of oxygen and hydrogen isotope studies to problems of hydrothermal alteration and ore deposition: Economic Geology, v. 69, no. 6, p. 843-883.

- 1986, Igneous rocks-II. Isotopic case studies of circumpacific magmatism, in Valley, J.W., Taylor, H.P., Jr., and O'Neil, J.R., eds., Stable isotopes in high temperature geological processes: Mineralogical Society of America, Reviews in Mineralogy, v. 16, p. 273-317.

Taylor, H.P., Jr., and Epstein, S., 1962, Relationship between ${ }^{18} \mathrm{O} /{ }^{16} \mathrm{O}$ ratios in coexisting minerals of igneous and metamorphic rocks: Geological Society of America Bulletin, v. 73, no. 4, p. 461-480.

Taylor, H.P., Jr., and Sheppard, S.M.F., 1986, Igneous rocks I. Processes of isotopic fractionation and isotope systematics, in Valley, J.W., Taylor, H.P., Jr., and O'Neil, J.R., eds., Stable isotopes in high temperature geological processes: Mineralogical Society of America, Reviews in Mineralogy, v. 16, p. 227-272.

Taylor, S.R., and McClennan, S.M., 1985, The continental crust-Its composition and evolution: Palo Alto, Blackwell Scientific, 312 p.

U.S. Department of Energy, 1988, Site characterization plan, Yucca Mountain site, Nevada Research and
Development Area, Nevada: U.S. Department of Energy Report DOE RW/0199, 8 vols.

Valley, J.W., Taylor, H.P., Jr., and O’Neil, J.R., eds., 1986, Stable isotopes in high temperature geological processes: Reviews in Mineralogy, v. 16,570 p.

Vaniman, D.T., and Whelan, J.F., 1994, Inferences of paleoenvironment from petrographic, chemical and stableisotope studies of calcretes and fracture calcites, in High Level Radioactive Waste Management, 5th [Proceedings]: La Grange Park, Ill., American Nuclear Society, p. 2730-2737.

Weiss, S.I., Noble, D.C., and Larson, L.T., 1994, Potential for undiscovered mineral deposits at Yucca Mountain, NV-Host rocks, timing and spatial distribution of nearby mineralization [abs.]: Geological Society of America Abstracts with Programs, v. 26, no. 7, p. A311.

Winograd, I.J., Szabo, B.J., Coplen, T.B., and Riggs, A.C., 1988, A 250,000-year climatic from Great Basin vein calcite?implications for Milankovich theory: Science, v. 242, p. $1275-1280$.

Younker, J.L., and others, 1992, Report of early site suitability evaluation of the potential repository site at Yucca Mountain, Nevada: Science Applications International Corporation Report SAIC-91/8000, p. 2-121-2-145. 